\title{
Ecologically Sensitive Sites in Africa
}

\section{Volume I: Occidental and Central Africa}

Benin

Cameroon Central African Republic

Congo Côte d'ivoire

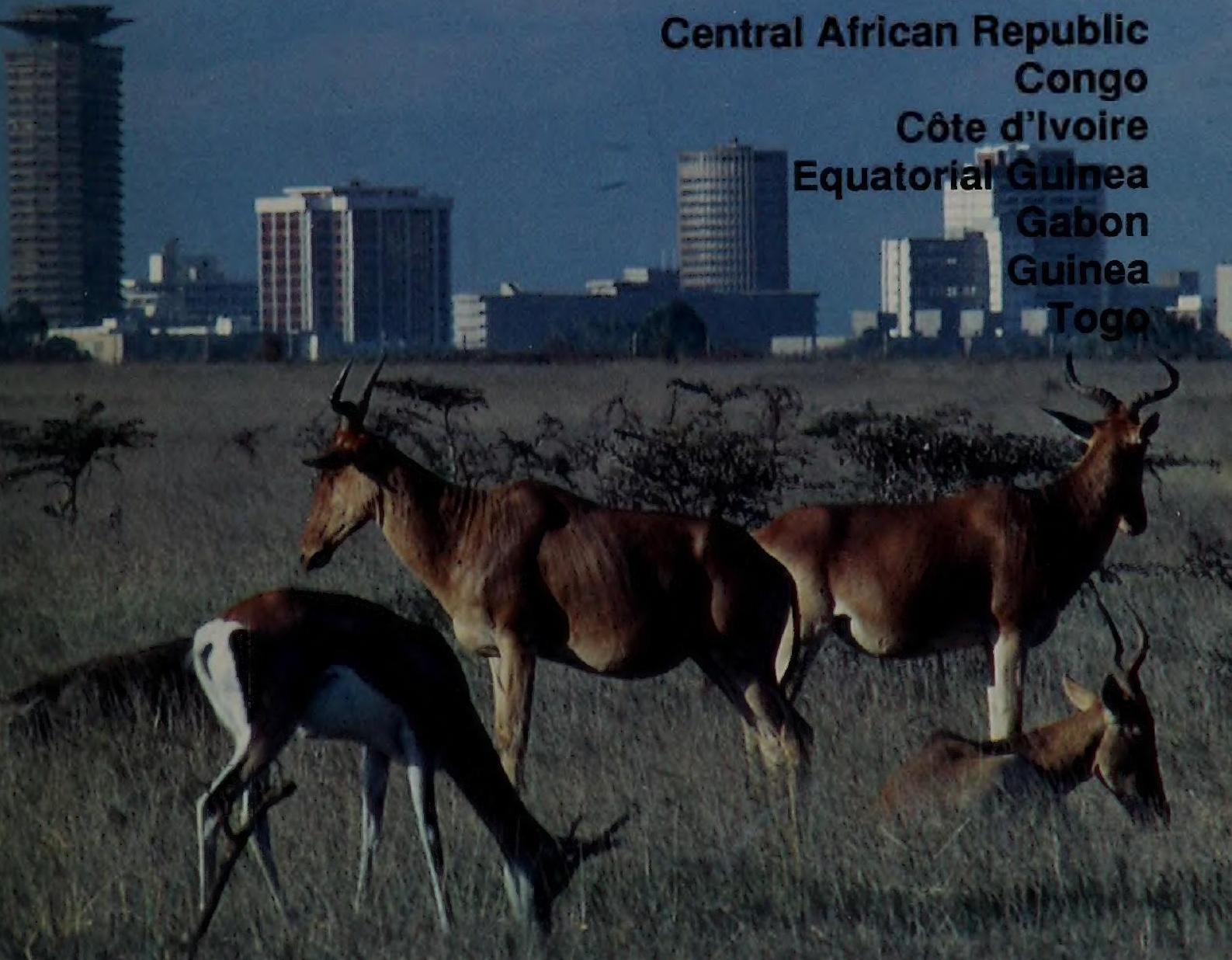

Compiled by the World Conservation Monitoring Centre 


$$
5457
$$




\title{
Ecologically Sensitive Sites in Africa
}

\author{
Volume I: Occidental and Central Africa
}
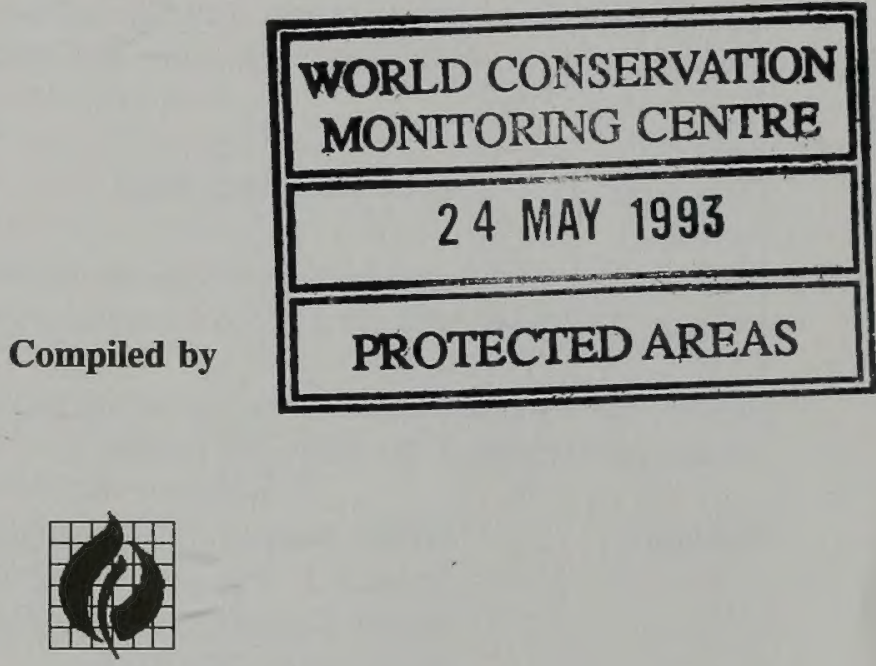

World Conservation Monitoring Centre

Cambridge, UK

for

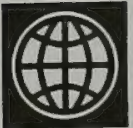

The World Bank

Washington DC, USA

The World Bank

1993 
Published by The World Bank, Washington, DC, USA.

Prepared by the World Conservation Monitoring Centre (WCMC), 219 Huntingdon Road, Cambridge, CB3 ODL, UK.

WCMC is a joint venture between the three partners who developed The World Conservation Strategy and its successor Caring for the Earth: IUCN-World Conservation Union, UNEP-United Nations Environment Programme, and WWFWorld Wide Fund for Nature. Its mission is to provide an information, research and assessment service on the status, security and management of the Earth's biological diversity as the basis for its conservation and sustainable use.

Copyright: 1993 The World Bank

Reproduction of this publication for educational or other non-commercial purposes is authorised without prior permission from the copyright holder.

Reproduction for resale or other commercial purposes is prohibited without the prior written permission of the copyright holder.

Citation: World Bank (1993). Ecologically Sensitive Sites in Africa. Volume I: Occidental and Central Africa. Compiled by the World Conservation Monitoring Centre for The World Bank, Washington, DC, USA.

Printed by: $\quad$ The Burlington Press, Cambridge, UK.

Cover illustration: Nairobi City Skyline with Kongoni and Grant's Gazelles, RIM Campbell.

Available from: The World Bank, 1818 H Street NW, Washington, DC 20433, USA.

This publication has been prepared for Bank use. The views and interpretation herein are those of the authors and should not be attributed to the World Bank, to its affiliated organisations or to any individual acting on their behalf.

The designations of geographical entities in this book, and the presentation of the material, do not imply the expression of any opinion whatsoever on the part of WCMC or other participating organisations concerning the legal status of any country, territory, or area, or of its authorities, or concerning the delimitation of its frontiers or boundaries.

The views of the authors expressed in this publication do not necessarily reflect those of WCMC or other participating organisations. 


\section{TABLE OF CONTENTS}

Page

Preface iii

\section{Section I}

INTRODUCTION $\ldots \ldots \ldots \ldots \ldots \ldots \ldots \ldots \ldots \ldots \ldots$

What is an ecologically sensitive area? ............... xiii

Conceptual framework for designation and

classification of ecologically sensitive areas ............. xix

Categories and management objectives of protected areas . . . . . . . . xxv

Developing guidelines on the relationship between various

types of Bank projects and ecologically sensitive areas $\ldots \ldots \ldots$ xxvii

Minimum quality standards for ecologically sensitive areas $\ldots \ldots \ldots \ldots$ xxxii

Conclusions . . . . . . . . . . . . . . . . . . xxxviii

References ..................... . . . . . . . . .

World Bank Wildlands Operational Policy Note No. 11.02

Wildlands: Their Protection and Management in

Economic Development with Annexes . . . . . . . . . . . x xli

\section{Section II}

Information Sources

OCCIDENTAL AND CENTRAL AFRICA

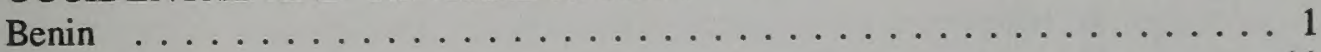

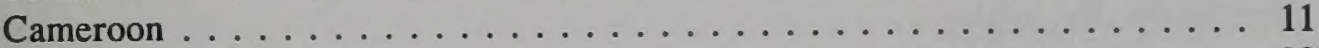

Central African Republic . . . . . . . . . . . . . . . . . 29

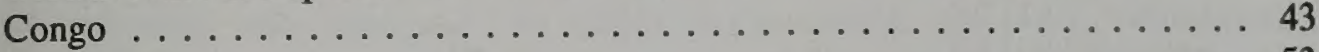

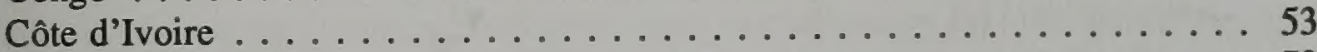

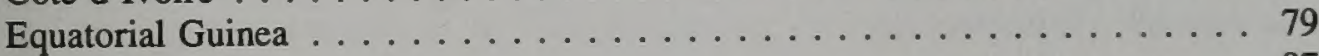

Gabon ............................... 87

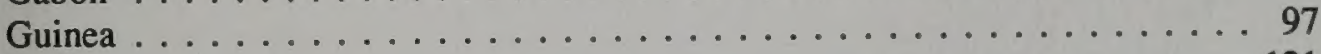

Togo . . . . . . . . . . . . . . . . . . . . . . . . . 121

References ......................... 127 



\section{ECOLOGICALLY SENSITTVE SITES IN AFRICA}

\section{PREFACE}

During the last two decades, there has been growing evidence that environmental degradation in its many forms constitutes a threat of growing significance to economic development. In addition, the rapid evolution of the environmental agenda has led to an increased understanding of the interdependence among economic activities and their environmental consequences, both within and between countries. The economic and physical interdependence between nations is illustrated by the emergence of new kinds of environmental problems, such as the deterioration of the ozone layer, the greenhouse effect, tropical deforestation, and the transboundary movement of hazardous wastes.

The Bank has been active in the field of environmental protection and, in the last decade, has financed numerous projects containing environmental components as well as several free standing environmental projects, which have had solely environmental objectives, such as reforestation, watershed management and pollution control. Through the introduction on new directives on environmental assessment, environmental action plans, forestry policy, the global environmental facility, resettlement, indigenous people and wildlands, the Bank has definitely distinguished itself as a leader in environmental protection.

Despite the above efforts, it became evidently clear that the Bank's response did not match the changing realities in the degree of effort devoted to environmental matters or in the approaches actually used. This combined with a few well publicised cases in which World Bank projects actually had some negative environmental consequences - such as contributing to the destruction of tropical rain forests and posing threats to wildlife populations, indigenous people, and established human settlements, prompted the Bank to rethink and adjust its policies toward environmental management. In its recent reorganisation, the Bank management decided to bring environmental concerns more systematically into the mainstream of its operation by establishing a Vice Presidency on Environmentally Sustainatle Development.

This new action reiterates the Bank's commitment to bringing environmental issues into the mainstream of the lending operations and policy work. Partly influenced by global events such as the Rio Summit and from the Bank's own experience in environmental work, there continues to be a general consensus on five priority areas which will require the Bank's special attention and also the attention of its member countries. These include destruction of natural habitats; land degradation; degradation and depletion of fresh water resources; urban, industrial, and agricultural pollution; and degradation of the "global commons". Although these five areas have been addressed in the Bank's operations through various country focused environmental action plans, through coverage of environmental issues in country economic and sector work, and through actual lending operations, there has been expressed concern by task 
managers on the availability of environmental information on which to base certain decisions.

This publication is made in response to requests from task managers in the Africa region who wanted to know the location and properties of the ecologically sensitive sites in Africa to which they could refer while implementing Bank projects in the region. This publication is also made to assist task managers to comply with the Bank's Operational Policy Note No. 11.02 on "Wildlands: Their Protection and Management in Economic Development". The publication has been compiled by the World Conservation Monitoring Centre, UK in collaboration with the Africa Environment Division of the Technical Department at the World Bank. It contains the most up-to-date available data and we hope it will find wider application beyond the Bank's operations.

\author{
Walter Lusigi \\ Senior Ecologist \\ World Bank \\ Environment Division \\ Technical Department \\ Africa Region
}




\title{
SECTION I
}

\section{ECOLOGICALLY SENSITIVE SITES IN AFRICA}

\author{
A summary of key issues
}

\section{INTRODUCTION}

The challenge facing nations today is no longer deciding whether conservation is a good idea, but rather how it can be implemented in the national interest and within the means available to each country. (WCED, 1987)

In order to achieve sustainable development, environmental protection shall constitute an integral part of the development process and cannot be considered in isolation from it. (Principle 4, Rio Declaration on Environment and Development, UNCED 1992)

Environmental concerns are much in the news. Drought, poacher wars and civil strife are evident in many African countries, and a general feeling of malaise affects much of the continent. As a result, the natural and semi-natural ecosystems of Africa are having increasing stresses put upon them, and ecologically sensitive areas are being degraded through mismanagement, rather than conserved through effective management. This has serious implications for human well-being, as a wide range of benefits can result from investment in conserving ecologically sensitive areas. The value of such benefits will vary considerably from area to area and resource to resource, but most will fall into one or other of the following categories:

- Fixation of solar energy through photosynthesis, transfers energy through green plants into natural food chains, providing the support system for species which are harvested

- Maintenance of evolutionary processes and genetic variability

- Maintenance of water cycles, including recharging groundwater, protecting watersheds, and buffering extreme water conditions (such as flood and drought)

- Regulation of climate, at both macro- and micro-climatic levels (including influences on temperature, precipitation, and air turbulence)

- Production of soil and protection of soil from erosion, including protecting coastlines from erosion by the sea 


\section{Ecologically Sensitive Sites in Africa}

- Storage, cycling and buffering of essential nutrients, including carbon, nitrogen, and oxygen

- Absorption and breakdown of pollutants, including the decomposition of organic wastes, pesticides, and air and water pollutants

- Provision of direct support to local communities through sustainable resource use

- Provision of recreational-aesthetic, socio-cultural, scientific, educational, spiritual, and historical values

Because the benefits of conservation are so important to society, the rate of natural habitat loss (see Table 1) and threats to species in Africa (see Table 2) is a source of great concern throughout the world.

Many development plans fail to recognize that retention of natural systems may constitute the optimal use of certain areas, in economic as well as ecological terms. Instead of conserving the rich resources of forest, wetland, and sea and managing them on a sustainable basis, current processes of development are depleting many biological resources at such a rate that they are rendered essentially non-renewable, thereby potentially reducing the benefits to society in the longer term. Experience has shown that market forces alone will often lead to such over-exploitation, largely because many of the costs are external and simply ignored.

Since biological resources will be inadequately conserved by market forces alone, given current means of assessing costs and benefits, effective government intervention is required to meet the conservation needs of society. Environmental management measures available to governments for promoting conservation include:

- establishing national parks and other types of protected area

- promoting citizen awareness and action through public education and supporting non-governmental conservation organizations

- modifying resource exploitation through legal or administrative means

- implementing international conservation conventions, particularly the Convention on Biological Diversity

- establishing government departments or ministries responsible for environmental matters

- implementing special action to conserve threatened species and habitats 
Ecologically Sensitive Sites in Africa

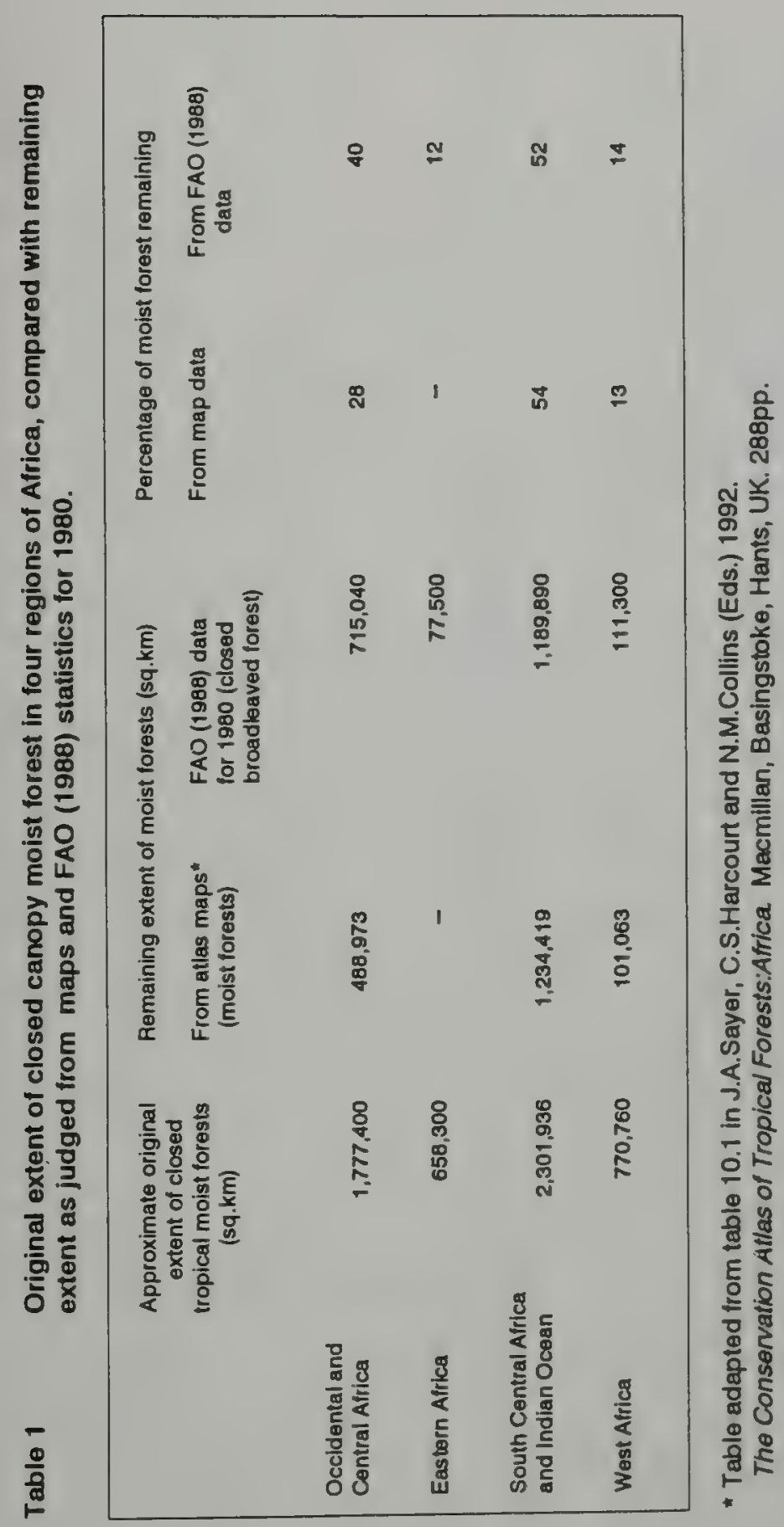


Ecologically Sensitive Sites in Africa

Table 2 Numbers, by country, of endemic and threatened mammals and birds

\begin{tabular}{|c|c|c|c|c|}
\hline & $\begin{array}{l}\text { Known } \\
\text { species }\end{array}$ & $\begin{array}{l}\text { Endemic } \\
\text { spocies }\end{array}$ & $\begin{array}{l}\text { Threatened } \\
\text { species }\end{array}$ & $\begin{array}{l}\text { Threatened } \\
\text { endemics }\end{array}$ \\
\hline Angola & 1,148 & 16 & 26 & 4 \\
\hline Benin & 818 & 0 & 12 & 0 \\
\hline Botswana & 723 & 0 & 15 & 0 \\
\hline Burkina Faso & 644 & 1 & 11 & 0 \\
\hline Burundi & 740 & 0 & 9 & 0 \\
\hline Cameroon & 1,145 & 21 & 44 & 8 \\
\hline CAR & 877 & 2 & 14 & 0 \\
\hline Chad & 630 & 0 & 22 & 0 \\
\hline Congo & 700 & 1 & 15 & 0 \\
\hline Cote d'Ivoire & 913 & 2 & 27 & 1 \\
\hline Djibouti & $?$ & 0 & 9 & 1 \\
\hline Equatorial Guinea & 576 & 4 & 18 & 1 \\
\hline Ethiopia & 1,091 & 52 & 39 & 16 \\
\hline Gabon & 807 & 3 & 21 & 4 \\
\hline Gambia & 597 & 0 & 8 & 0 \\
\hline Ghana & 943 & 1 & 21 & 0 \\
\hline Guinea & 719 & 1 & 23 & 0 \\
\hline Guinea-Bissau & 484 & 0 & 7 & 0 \\
\hline Kenya & 1,376 & 17 & 35 & 7 \\
\hline Lesotho & 321 & 0 & 9 & 0 \\
\hline Liberia & 783 & 3 & 28 & 1 \\
\hline Libya & 156 & 4 & 21 & 0 \\
\hline Madagascar & 355 & 164 & 81 & 78 \\
\hline Malawi & 825 & 0 & 17 & 0 \\
\hline Mali & 784 & 0 & 20 & 0 \\
\hline Mauritania & 110 & 1 & 19 & 0 \\
\hline Mozambique & 845 & 2 & 21 & 0 \\
\hline Niger & 604 & 0 & 16 & 0 \\
\hline Nigeria & 1,105 & 4 & 35 & 3 \\
\hline Rwanda & 820 & 0 & 18 & 0 \\
\hline Senegal & 780 & 1 & 16 & 0 \\
\hline Sierra Leone & 761 & 0 & 20 & 0 \\
\hline Somalia & 810 & 19 & 24 & 6 \\
\hline Sudan & 1,205 & 7 & 25 & 1 \\
\hline Swaziland & 428 & 0 & 5 & 0 \\
\hline Tanzania & 1,322 & 25 & 56 & 19 \\
\hline Togo & 826 & 1 & 10 & 0 \\
\hline Tunisia & 251 & 1 & 20 & 0 \\
\hline Uganda & 1,304 & 7 & 28 & 3 \\
\hline Zaire & 1,501 & 48 & 58 & 19 \\
\hline Zambia & 961 & 3 & 20 & 3 \\
\hline Zimbabwe & 831 & 2 & 15 & 0 \\
\hline
\end{tabular}

Data from: World Conservation Monitoring Centre 1992. Global Biodiversity Status of the Earth's Living Resources. Chapman and Hall. 594pp. 
- building information gathering and monitoring capabilities as the basis for improved resource planning

- establishing special training programs for government officials

- promoting integrated rural development schemes which incorporate conservation

- developing ex situ facilities for preserving threatened genetic resources, in support of in situ conservation programs

However, conservation actions have been underway in Africa many years, yet natural habitats are still being lost at a rapid rate. Experience has taught the hard lesson that traditional protected areas will be unable to conserve most biological resources by themselves. Additional approaches to conservation are required to more effectively integrate protected areas within the broader processes of land-use planning, and to bring about policy shifts in a wide variety of sectors which have impacts on ecologically sensitive areas.

This has been the message of a number of reports and meetings in recent years, and is clearly stated within the articles of the Convention on Biological Diversity.

Article 8 of the Convention deals specifically with in situ conservation. It calls on contracting parties to:

- establish a system of protected areas where special measures are needed to conserve biodiversity

- develop guidelines for the selection, establishment and management of such areas

- manage biodiversity both within protected areas and in the wider landscape

- promote the protection of ecosystems, natural habitats and the maintenance of viable populations of species

- promote environmentally sound and sustainable development in areas adjacent to protected areas

- restore degraded ecosystems and promote the recovery of threatened species

- control or eradicate alien species that threaten indigenous biodiversity

- respect and maintain the knowledge and practices of indigenous and local communities, including the equitable sharing of benefits arising from the utilization of such knowledge and practices 


\section{- develop appropriate environmental legislation}

These measures are all highly pertinent to the identification and conservation of ecologically sensitive areas, and one of the top priorities in promoting sustainable development must be to encourage countries to ratify the convention. The first step in implementation is to undertake a comprehensive national assessment of the status of, and threats to, the country's biodiversity, its utilization and management, the economic benefits it provides and the costs of its effective management. This process includes the identification of ecologically sensitive areas, both within and outside existing protected area systems. The management of these areas to maintain their ecological integrity, and thus to maximise their potential economic benefits, is then prescribed in the national biodiversity strategies and action plans countries are called upon to produce under Article 6 of the Convention.

Particularly important therefore is the development of management programs using a broad systems approach based on an increasingly sophisticated ecological understanding of ecosystem productivity, processes, and dynamics. Integrated rural development can draw on national conservation strategies, river basin development strategies, environmental impact assessment, Geographic Information Systems and other technologies to promote environmentally sound management of large ecosystems containing both natural and transformed habitats. While such programs can make important contributions to conservation of biodiversity, they also contribute indirectly through stabilizing resource use in areas which are not biologically diverse. These activities focus upon maintaining, or restoring, natural ecosystems so that the ecological and hydrological processes which they support are maintained, and the benefits which they provide to human society are made available on a sustainable basis.

By managing these ecosystems sustainably and stabilizing land-use, the root cause of many human population movements can be addressed, with biological diversity being a beneficiary. For example, in many parts of Africa, forests are being lost because of slash and burn agriculture. In most areas, the expansion of this agricultural practice is a consequence of non-sustainable resource use and declining agricultural productivity in other ecosystems which the rural poor have been forced to abandon. By focusing attention on restoring formerly productive agro-ecosystems, and by maintaining the ecological and hydrological processes which maintain the productivity of these systems, agricultural pressure on the marginal lands can be reduced and they can be allocated to activities which are more conducive to the conservation of biological diversity.

It is apparent that mechanisms need to be developed for identifying ecologically sensitive areas in a systematic manner and establishing minimum quality criteria for managing such areas. To enhance its contribution to sustainable development, the World Bank requires guidelines for rapid identification of ecologically sensitive areas, and needs to develop means of promoting special measures that could be incorporated 
in project planning and implementation to maintain the ecological integrity of such areas. The aim of this report is to assist in this process.

However, no simple recipe exists for determining how resources should be used. Ecological, social, political, economic, and technological factors all enter into the decision. Each of these factors can change over time, and because the factors are inter-related, a change in one can affect all the others. Therefore, while this discussion will concentrate on ecological factors, it will consider the others as well. In the final analysis, guidelines need to be applied by people exercising their best judgement given the current state of knowledge. The dynamic state of development in the Africa region is likely to continue, and building the capacity to adapt to constant change will require concerted action.

This section of the report is based on material drafted by Jeffrey $A$. McNeely, Chief Conservation Officer at IUCN - The World Conservation Union. The section was originally drafted in December 1991, and then revised in early 1993 by Robin Pellew and Jeremy Harrison of the World Conservation Monitoring Centre to take account of subsequent developments. 



\section{WHAT IS AN ECOLOGICALLY SENSITTVE AREA?}

\section{Introduction}

1.1 While many natural habitats are being converted into uses -- such as agriculture, aquaculture, or forestry -- which yield greater productivity to humans (at least in the short term), the natural value of some areas is so significant that they need to be converted with great care, or even left in their natural state. Areas of significant value in their natural state can be termed Ecologically Sensitive Areas (ESAs) (see Box 1). They may contain unique features, maintain key natural processes, support rare plants or animals and their habitats, or provide important breeding areas for wildlife. Some ESAs are natural, while others have been significantly altered by certain human activities. In terms of management, some ESAs will prosper through "benign neglect" while others will require intensive management to restore or maintain their natural values.

\section{Box 1: Ecologically Sensitive Areas}

Criteria for ecologically sensitive areas would include:

- provide protection of steep slopes, especially in watershed areas, against erosion

- support important natural vegetation on soils of inherently low productivity that would yield little of value to human communities if transformed

- regulate and purify water flow

- provide conditions essential for the perpetuation of species of medicinal and genetic conservation value

- maintain conditions vital for the perpetuation of species that enhance the attractiveness of the landscape or the viability of protected areas provide critical habitat that threatened species use for breeding, feeding or staging

Source: McNeely et al. 1990

1.2 In order to ensure effective management of ecologically sensitive areas, and to avoid inappropriate conversion, it is essential that criteria are developed which can be used to guide decisions on whether an area can be converted freely to alternative uses, can be converted to only certain uses (such as forest production), or should not be converted at all. 
1.3 A useful scale for seeking an answer is the ecosystem, a community of organisms interacting with the local living and non-living elements of the environment and forming a system in which life-sustaining processes are maintained. The ecosystem involves the accumulation, circulation, and transformation of matter and energy through such biological processes as photosynthesis and decomposition. The processes often work though the means of water, which provides a means of transfer and storage of energy and materials used by living organisms within the ecosystem.

1.4 The boundaries of an ecosystem are often identified by changes in vegetation, soil, or landscape form. The scale of the ecosystem depends on the purpose of analysis; a small mountain pond is an ecosystem, and so is the mountain on which it is located. Almost all ecosystems are connected with others of various scales. Protected areas with artificial boundaries may be whole or partial ecosystems, depending on the size of the area and the form of the boundary; a protected area surrounded by forest is a much different ecosystem to a similar one surrounded by agricultural land.

1.5 Some ecosystems are relatively robust and resist permanent damage, while others are very sensitive to disturbance and may require long periods to recover from disruption. Grasslands naturally subject to periodic fires, are robust, while mature tropical rain forests may be easily disturbed and require decades or even centuries to recover. Particularly sensitive ecosystems include those which lie on geologically unstable substrata, such as steep slopes subject to landslides, and those which are dependent on influences from outside the system, such as estuaries and deltas. Ecosystems need to be classified according to their sensitivity to certain kinds of treatment by people, and the most useful indicators of sensitivity need to be identified.

1.6 People have shown the capacity to convert almost any piece of natural habitat into agricultural land which can produce a crop for at least a few growing seasons. But areas which are inappropriate to such use quickly degrade into wastelands, such as the great expanses of Imperata grasslands found in much of tropical Asia; worse, inappropriate conversions of watersheds, such as through illegal logging, can contribute to very high human costs downstream through floods, erosion, siltation, and other external factors.

1.7 Logically, an objective survey of all remaining natural habitats should first be conducted to ascertain which have the highest value in their present state, and the least value if transformed. In practical terms, and as a working rule of thumb where complete information is not yet available, it may be best to accept the rationale behind the process of selection of protected areas already followed. This would mean that first priority ESAs should include areas which are already given legal protection (though recognizing that not all areas given legal protection really qualify as an ESA); second priority ESAs should include all 
areas which have been proposed for protection; and third priority ESAs should be all other areas where natural habitat remains.

\section{Legally protected areas}

2.1 Areas which have been given legal protection preventing conversion to other uses should be among those not considered for alteration or conversion; their contribution to development is through maintaining their relatively natural state. In fact, the World Bank's policy on wildilands (World Bank, 1986) expressly prohibits the use of IBRD funds to convert legally protected areas to any other uses except under the most stringent and exceptional conditions.

As development has accelerated in the past few decades, the governments in the region have recognized the importance of legally protected areas as part of the overall pattern of land use, though of course the effectiveness of such legal regimes varies widely. Many of these areas have been established in the past 30 years (see Fig. 1), and over that period administration and management of protected area systems has also changed in many countries. WCMC (1992) summarises how each of the national protected area systems is set up in SubSaharan Africa, and Lusigi (1992) discusses many of the challenges and issues facing protected areas management in Africa.

2.2 However, it would be a mistake to consider that once an area is legally established, then all threats have been removed. In fact, virtually all protected areas in the Africa have an uneasy relationship witt: the people living around them. The reasons for this are apparent: the local people pay most of the costs of conservation by not being able to harvest resources as they might wish, while the bulk of the benefits go to the nation at large or even to the international community. Governments need to seek additional means of redressing this imbalance, by ensuring that the costs of conservation are shared more widely, and that more of the benefits are delivered to the local communities.

2.3 Protected areas within the wildlife sector are often augmented by a range of designated areas established and managed by other sectors (such as forestry or fisheries) with management objectives which support a nature conservation function. The World Conservation Monitoring Centre (WCMC) has carried out research on areas within the forest sector, and is working on a series of reports which will show the extensive nature of their contribution in some countries. Review of the conservation value of some of these areas on the ground may be a valuable next step (the development community is currently funding such a study in Sri Lanka).

2.4 In addition to being protected under national legislation, some areas are given further protection under international legislation, notably the Convention on Wetlands of International Importance (Ramsar, 1971) and the Convention 
Ecologically Sensitive Sites in Africa

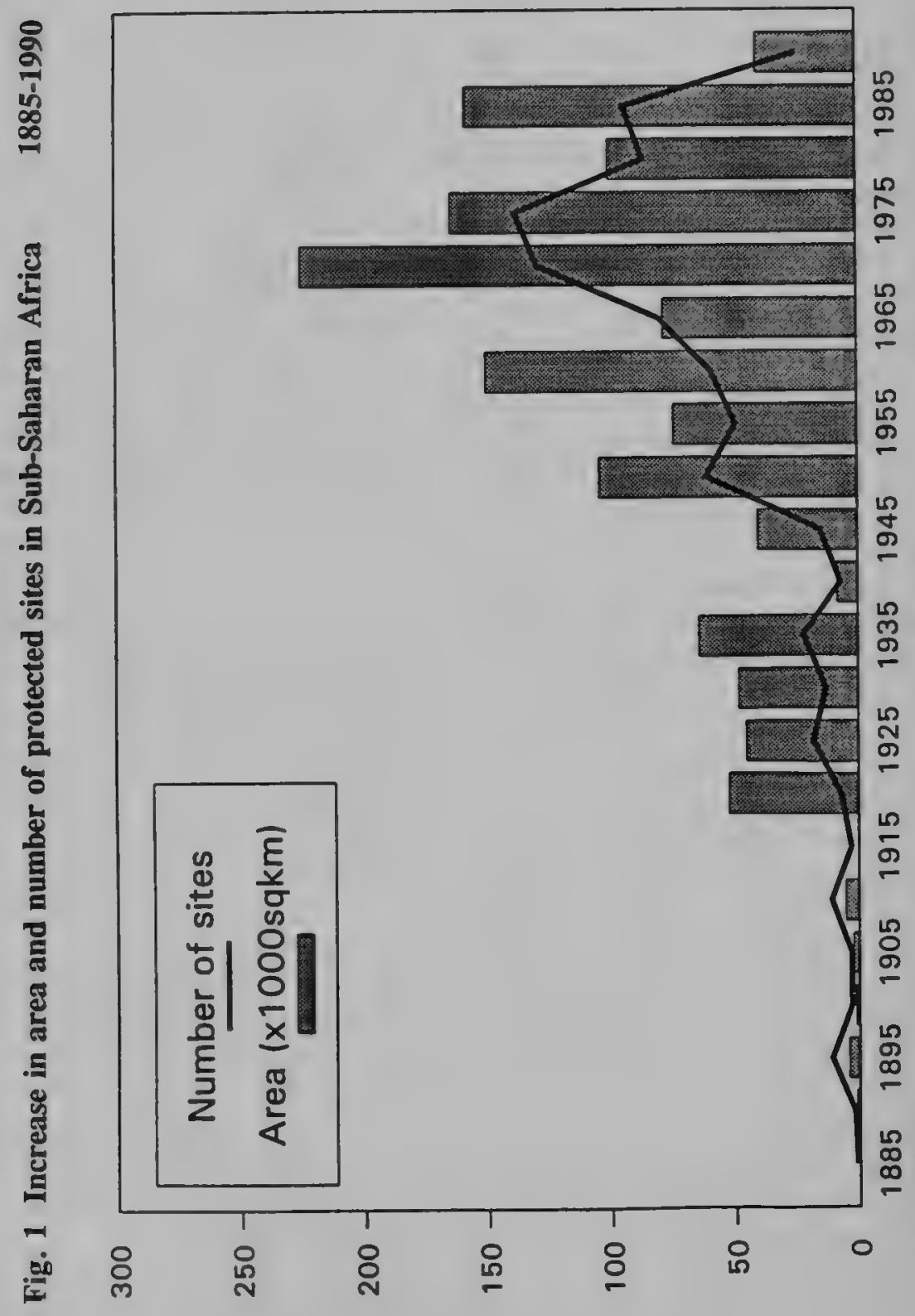


Concerning the Protection of the World Cultural and Natural Heritage (Paris, 1972). The list of areas given such protection expands each year as the States Party add areas to the list. Areas currently given such protection are identified and described in later sections.

2.5 While not a convention, the Biosphere Reserve programme of Unesco also has considerable relevance to the region. As part of UNESCO's Man and the Biosphere Programme (MAB), a biosphere reserve is established to conserve representative natural areas throughouc the world, and to use these areas to further understanding of the interaction between man and nature. Biosphere reserves ideally take an existing protected area as the core, then incorporating land around the core with varying degrees of human intervention are permitted. Biosphere reserves in Africa are also listed in later sections.

\section{Other critical habitats}

3.1 While many countries in Africa have an impressive record on establishing protected areas, there are many gaps in coverage, with many ESAs of high priority for conservation yet to receive any effective management. The regional systems review carried out by IUCN (IUCN/UNEP, 1986) identifies a number of important sites, as does the action plan for protected areas in Africa (IUCN, 1987) and in the African Biodiversity Review prepared by IUCN (Stuart and Adams, 1990). Many of these unprotected ESAs may in fact deserve higher attention than the existing protected areas, because they are more liable to alteration to inappropriate uses, and a number are identified in the body of this report.

3.2 Even if they are not yet protected, habitats can also be considered ecologically sensitive areas if they meet the criteria identified in Box 3. The identification of such ESAs outside of existing protected areas ideally requires considerable research and information, but the pace of development is such that it will inevitably prove necessary to take some relatively arbitrary decisions on the limited information available. In making such decisions, use should be made of all available information, including both national and international reviews.

3.3 Threatened species are of particular concern to both governments and the general public. Many such species are protected under national legislation, and in addition many African countries are members of international conventions which provide protection to threatened species. It is widely accepted that the best way to conserve species is through protecting their habitats while simultaneously controlling exploitation. Critical habitats of threatened species are particularly important ESAs.

3.4 Potential ESAs can also be identified from digitized data on the distribution of key species using a Geographic Information System (GIS). By overlaying such 
distribution data onto habitat maps, sites of particular species richness can be identified. These should then be priority areas for ground surveys. The application of information technology in this way enables proactive conservation planning to maintain the ecological integrity of such areas before they are disturbed by unsustainable management practices.

3.5 Information on the status and distribution of both habitats and species is central to the study of biodiversity conservation within a country, and a key part of both protected area systems reviews and the development of the national biodiversity strategies necessary for implementation of the Convention on Biological Diversity. Information is often widely distributed, and effort is required to bring the information together, and to develop research and monitoring programs to support biodiversity conservation. A range of international organizations, including UNEP and WCMC are in a position to support such activities.

\section{Areas to be rehabilitated}

4.1 Many ESAs have already been over-exploited, with resulting degradation. These areas need to be rehabilitated so that they can once again make important contributions to sustainable development. Since tropical forests often grow on soils which are poor in cations or suffer from other deficiencies, attempts at agriculture are often followed rather quickly by abandoned fields and degraded vegetation. As a result, large areas of Africa are covered by devastated landscapes which are productive only for grazing at a very low stocking density. With proper economic incentives, such areas can be made productive again, either for agriculture, forestry, or conservation of biological diversity.

4.2 It may be more expensive in the short run to reconstitute damaged ecosystems than to conserve new lands (and is certainly more expensive to reconstitute damaged ecosystems than it is to exploit new ones), but it will often be as economically efficient in the long run to rebuild degraded local ecosystems rather than to exploit (and degrade, requiring rebuilding) other more remote land, which may itself be sensitive to degradation.

4.3 Given the right circumstances it is also possible to develop ecologically sensitive areas from lands which previously had no particular value, through careful development of new habitats. This may have economic as well as ecological benefits. 


\section{CONCEPTUAL FRAMEWORK FOR DESIGNATION AND CLASSIFICATION OF ENVIRONMENTALLY SENSITIVE AREAS}

\section{Introduction}

1.1 Conservation of biological resources has become an important item on every country's development agenda. Conservation in the modern sense is part of development. As defined by the World Conservation Strategy, it means: "The management of human use of the biosphere so that it may yield the greatest sustainable benefit to present generations while maintaining its potential to meet the needs and aspirations of future generations. Thus conservation is positive, embracing preservation, maintenance, sustainable utilization, restoration, and enhancement of the natural environment" (IUCN, 1980).

1.2 Conservation of biological resources is not a new idea. Farmers have always had the sense to avoid eating the seeds for growing next year's crop, to select the seeds which have the most favourable characteristics, and to plant a wide variety of crops. Herders don't slaughter their breeding stock, and they select the individuals for breeding which are the easiest to manage, have the most meat, or display other desirable traits. For most of human history, the natural world has been protected from the most disruptive human influences by cultural/ecological factors such as taboos preventing over-exploitation, tribal warfare which kept wide areas as wilderness "buffer zones" between groups, land ownership by ancestors or lineages rather than individuals, relatively sparse human populations, and so on.

1.3 But during the last few generations, economic growth based on the conversion of fossil fuels has spurred such rapid expansion of human numbers that new approaches to conservation are required. One such approach has been the establishment within the past 100 years of explicit government policies aimed at ensuring that wild living resources are conserved, usually through the designation of particular ecologically sensitive areas as national parks or other sorts of protected areas. Today, all but a small handful of countries have national parks and national legislation promoting conservation (see Fig. 2). Most governments have established wildlife management agencies, joined international conservation conventions, and built environmental considerations into the national education system. Non-governmental organizations are active throughout the region in promoting public awareness of conservation issues, including those dealing with biological diversity.

1.4 The conservation movement has been led by naturalists. While their contributions have been fundamental, they are unable to address fully the basic problems of conservation because the limiting factors are not biological, but rather political, economic, and social. The decisions affecting the natural 


\section{Ecologically Sensitive Sites in Africa}

Fig.2 Percentage of each country within protected area system (source: WCMC)

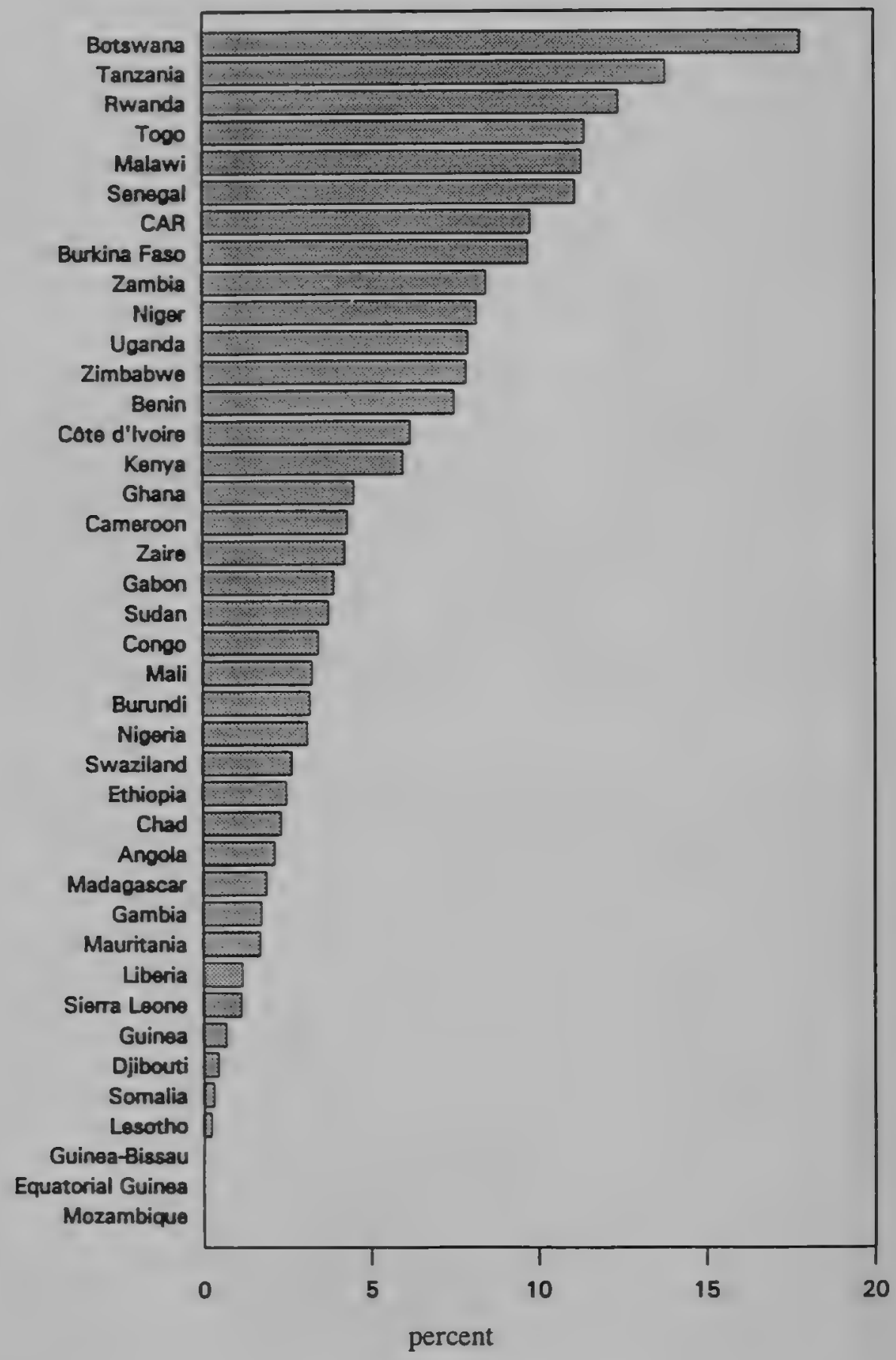


environment are influenced by pressures and incentives that go far beyond the relatively straight-forward technical considerations of what might in theory be best for the ecologically sensitive areas, and consider in addition questions of social equity, political possibility, and technical feasibility.

1.5 Advice on delivering conservation action needs to be sought from development practitioners, engineers, politicians, rural sociologists, agronomists, and economists. In the last analysis, local resource users are the ones who make local-level decisions, and their decisions are affected above all by enlightened self-interest. Those seeking to conserve ESAs need to be able to identify legitimate self-interests of rural people, and design ways of ensuring that the interests of ESAs and community self-interest coincide. Development aid agencies, including the Bank, therefore have an important role to play.

1.6 It has become apparent that a sectoral approach to managing ESAs is unlikely to be successful, even in the short run. While government institutions responsible for wildlife and protected areas need strengthening, even the most successful conservation programs will fail unless they are supported by appropriate developments in other sectors. Progress in sustainable approaches to forestry, agriculture, rural development, international trade, energy, population, national security, and other areas are so essential to the success of efforts to conserve ESAs that they deserve as much attention as the traditional conservation-related sectors.

1.7 The need for a broad based multi-sectoral approach to conservation is clearly identified in both the Global Biodiversity Strategy (IUCN/UNEP/WRI, 1992) and the Convention on Biological Diversity. Under the convention, countries will be required to prepare national biodiversity strategies and action plans, and to report on their implementation. These plans will need to focus on biodiversity outside the confines of protected areas, and address the fundamental requirements of reconciling the pressures of human development with conservation of ESAs in the wider landscape.

\section{Criteria for designating and managing Environmentally Sensitive Areas}

2.1 In planning a system to protect ESAs for supporting national development goals, criteria for selection and management are essential. Criteria will enable a relatively systematic comparison of different sites; help communicate to decision-makers why certain areas or policy initiatives are important; help focus research on the most important questions; promote the drawing of boundaries for the ESA by specifying the features which need special management; and facilitate public information programs.

2.2 In seeking to identify which sorts of protective regimes are most appropriate for each major ESA (including, but not limited to, designation as a protected area), 
local social, political, and economic factors need to be considered along with the ecological ones. The following set of criteria are presented in rough descending order of importance, though modifications will be required for adapting to each particular situation. Each criterion is presented as an ideal against which each site can be considered. No site can be expected to meet the ideal, but the criteria can provide a basis for comparing sites against each other. In some cases, it may be appropriate for planning purposes to assign numerical scores to the various criteria, with relatively higher scores being assigned to the first four criteria.

a) Criteria which determine the importance of the site to human society

Economic benefit. The site provides obvious long-term economic benefits, such as watershed protection or tourism (even though their initial establishment might involve short-term economic disruptions).

Diversity. The site has a great variety of species and ecosystems, and is sufficiently large to contain viable populations of most species; it contains a variety of geomorphological features, soils, water regimes, and microhabitats.

Critical habitat, international. The site is essential to the survival of one or more threatened species which occurs in no other country, contains the only example of certain types of ecosystems, or contains landscapes of outstanding universal value.

Critical habitat, national. The site is essential to the survival of one or more species which are threatened nationally or internationally, or contains the nation's only example of certain types of ecosystems. The ecological functioning of the area is vital to the healthy maintenance of a natural system beyond its boundaries (such as habitat for migratory species, an important catchment area for lowland irrigation systems, protection of the coast against typhoons, etc.).

Cultural diversity. The site supports populations of indigenous people who have developed mechanisms for living in a sustainable balance with the natural ecosystems, and whose continued presence in the ESA would help ensure that the diversity of the area is maintained.

Urgency. Action is required quickly at the site in order to avert an immediate threat (though it should be realized that this is often a "damage control" action; it is usually best to protect far in advance of threat).

b) Criteria to determine additional elements which enhance the value of the site 
Demonstration. The site demonstrates the benefits, values, or methods of protection, and can show how to resolve conflicts between natural resource values and human activities.

Representativeness. The site is representative of a habitat type, ecological process, biological community, physiographic feature, or other natural characteristic.

Tourism. The site lends itself to forms of tourism compatible with the aims of conservation; this criterion is often related to those of economic benefit and social acceptance.

Landscape. The site has features of outstanding natural beauty; these are usually also unique, easily destroyed, and attractive to tourists and any alteration would significantly reduce the area's amenity value.

Recreation. The site provides local communities with opportunities to use, enjoy, and learn about their natural environment.

Inventory and Monitoring. The site can serve as a non-manipulated area against which to measure changes occurring elsewhere; it can form the basis for assessing any ecological change. It can also serve as the site for detailed inventory of biodiversity to provide a baseline for long-term monitoring. Research has been carried out over a long period in the site, and major field studies have been carried out to provide a strong foundation on which new research can build. The site represents ecological characteristics of regional value so research can yield arguments that can have impacts far beyond the protected area.

Awareness. Education and training within the site can contribute knowledge and appreciation of regional values. The site can serve to exemplify techniques or scientific methods, making it particula:ly important for education purposes.

c) Criteria to help determine the management feasibility of a site

Social acceptance. The site is already protected by local people; or official protection by the government (particularly against outside exploitation) would be welcomed.

Opportunism. Existing conditions or actions at the site lend themselves to further action (such as the extension of an existing protected area or establishment of a buffer zone around an existing park).

Availability. The site can be acquired easily, through inter-departmental 
transfer, easements, or other legal forms of control.

Convenience. The site is accessible to researchers or students for scientific and educational uses.

\section{An expanded approach to protecting ecologically sensitive areas}

3.1 The best-known method of managing ESAs is through national parks, but many other types of reserves can also make contributions to both conservation and development, providing a range of management "tools" (Box 2). Ten years ago, the leading professionals in the field of national parks management, meeting in Bali, Indonesia, asserted that while national parks must be as carefully protected as ever, they must be supplemented by a range of other categories of protected areas in order to fully meet the social and economic development needs of modern society.

3.2 In the Bali Declaration (in McNeely and Miller, 1984), these authorities pointed out that protected areas are an indispensable element of conservation because they maintain those essential ecological processes that depend on natural ecosystems; they preserve the diversity of species and the generic variation within them, thereby preventing irreversible damage to our natural heritage; they maintain the productive capacities of ecosystems and safeguard habitats critical for the sustainable use of species; they provide opportunities for scientific research, education, training, recreation, and tourism; and they provide opportunities for the sustainable use of their natural resources for the benefit of local communities.

3.3 Since 1970, the world's networks of protected areas have expanded in extent by more than 80 per cent, around two-thirds of which are in the Third World (IUCN, 1990). The IUCN review of the protected areas of Africa suggested that the total expanse of protected areas in Africa needs to be increased at least three times, if the protected areas are to be effective in delivering nature's benefits to people. But given the pressures on the land today, these additional protected areas will need to be of a new type, far more flexible in their management than the traditional national parks. They may in fact merit a new term such as "Sustainably Managed Areas", or "Managed Resource Protected Areas".

3.4 New approaches to linking protected areas to surrounding lands are required if the appropriate benefits are to flow to society. While the specifics will vary from case to case, the major generalization is that local support for protected areas must be increased through such measures as education, revenue sharing, participation in decisions, complementary development schemes adjacent to the protected area, and, where compatible with the protected area's objectives, access to resources. In short, economic incentives should be used to encourage people to behave according to their own enlightened interest, and sound 


\section{Box 2: Categories and management objectives of protected areas}

While all protected areas control human occupancy or use of resources to some extent, there is wide variation in the degree of such control. Different protected areas are established for different purposes, and therefore have different management objectives. The following categories, which were first defined by IUCN in 1978, are currently under review. As a result of this review, it is likely that categories VI-VIII will be removed, and replaced with a new category VI - "Sustainably Managed Area" or "Managed Resource Protected Area".

I Scientific reserve/strict nature reserve. To protect nature and maintain natural processes in an undisturbed state in order to have ecologically representative examples of the natural environment available for scientific study, environmental monitoring and education, and for the maintenance of genetic resources in a dynamic and evolutionary state.

II National park. To protect relatively large natural and scenic areas of national or international significance for scientific, educational, and recreational use, under management by the highest competent authority of a nation.

III Natural monument/natural landmark. To protect and preserve nationally significant natural features because of their special interest or unique characteristics.

IV Managed nature reserve/wildlife sanctuary. To ensure the natural conditions necessary to protect nationally significant species, groups of species, biotic communities, or physical features of the environment when these require specific human manipulation for their perpetuation.

V Protected landscapes. To maintain nationally significant natural landscapes characteristic of the harmonious interaction of $\operatorname{man}$ and land while providing opportunities for public enjoyment through recreation and tourism within the normal life-style and economic activity of these areas.

VI Resource reserve. To protect the natural resources of the area for future use and prevent or contain development activities that could affect the resource pending the establishment of objectives based on appropriate knowledge and planning.

VII Natural biotic area/anthropological reserve. To allow the way of life of societies living in harmony with the environment to continue undisturbed by modem technology.

VIII Multiple-use management area/managed resource area. To provide for the sustained production of water, timber, wildlife, pasture, and outdoor recreation, with the conservation of nature primarily oriented to the support of the economic activities (although specific zones can also be designed within these areas to achieve specific conservation objectives).

Adapted from: IUCN (1990)

government policies should be designed to ensure that conservation is indeed in their self-interest. Such approaches were extensively discussed at the IV World Congress on National Parks and Protected Areas, held in Caracas, Venezuela, 
in 1992, and the Caracas Action Plan (IUCN, 1992) calls for new and innovative programs of integrated planning and cooperative management.

3.5 Another theme of the World Parks Congress held in Caracas, 1992, was the contribution made by other sectors. Strictly protected areas are unlikely to ever cover more than about five percent of Africa. Since permanent agriculture seldom covers more than a quarter of a nation's land area, ample land exists for forestry, shifting cultivation, grazing, and other uses which may, with proper management, contribute to conservation of biological diversity.

3.6 By themselves protected areas will never be able to conserve all, or even most, of the species, genetic resources, and ecological processes they were established to protect; these areas are just too small to support viable populations of wildlife if the areas are isolated from the surrounding lands. Far greater expanses are required for conservation than modern societies can afford to remove from direct production. The best answer to this dilemma is to select and manage protected areas to support the overall fabric of social and economic development, not as islands of anti-development, but rather as critical elements of regionally envisioned harmonious landscapes. Through a planned mix of national parks and other categories of ESAs, amidst productive forests, agriculture, and grazing, conservation can serve human communities and safeguard the well-being of future generations of people living in balance with their local ecosystems.

3.7 Improvements in conservation over the coming decades will be of three main types:

- the establishment and improved management of categories of protected areas where some kinds of human use are tolerated or even encouraged

- the establishment of new types of protected areas in degraded landscapes which have been restored to productive use for conservation

- management regimes in non-protected areas which bring sustainable benefits from harvesting biological resources to local communities

and will be founded on a rapidly improving information base to support management decisions. 


\section{DEVELOPING GUTDELINES ON THE RELATIONSHIP BETWEEN VARIOUS TYPES OF BANK PROJECTS AND ECOLOGICALLY SENSITTVE AREAS}

While many development projects have led to the abuse of ESAs, in fact a positive relationship between development projects and ESAs would be of benefit to both the project and the ESA. A series of guidelines can be developed for each major type of development project which would illustrate how the project can contribute to the viability of the ESA. The following examples indicate the sorts of guidelines which might be appropriate.

\section{Water resources development projects}

1.1 Natural vegetation cover on water catchments regulates and stabilizes water run-off. Deep penetration by tree roots or other vegetation makes the soil more permeable to rainwater so that run-off is slower and more uniform than on cleared land. As a consequence, streams in forested regions continue to flow in dry weather and floods are minimized in rainy weather. Water resources development projects -- dams, irrigation systems, urban water supply, and others -- depend on watershed protection to such an extent that many valuable reserves in these ESAs have been established by drawing support from the development projects involved; irrigation and energy agencies can therefore make powerful potential allies for protected areas which protect watersheds.

1.2 In many cases, the total costs of establishing and managing reserves which protect catchment areas can be met and justified as part of the hydrological investment. Guidelines should be developed to specify how the potential positive relationship between watershed protection and water resources development projects can be converted into reality.

1.3 One of the objectives of water resources development projects should to improved integration in the management of such resources. Guiding principles of integrated river basin management (Dugan, 1990) include:

a) The hydrological balance of the basin should be quantified, including measures of both water quantity and quality, and incorporating surface, upderground and coastal waters.

b) The values of all the major ecosystems in the basin should be identified, as well as the full range of biophysical processes upon which they depend.

c) The products and services taken from each part of the system should be inventoried and the minimum requirements for the sustenance of these 


\section{Ecologically Sensitive Sites in Africa}

features determined.

d) The short and long term impact on the environment of planned changes to the system should be determined, and appropriate compensatory measures should be implemented as required.

1.4 The establishment and management of protected areas in coastal and marine ESAs is still in its infancy, with most such areas being merely an extension seaward of existing terrestrial protected areas. Many critical habitats in the coastal zone need protection so that they can provide services to mankind on a continuous basis; these services include support for fish breeding, shoreline protection, and sustainable harvesting of construction materials.

1.5 Virtually all wetland habitats are important for fisheries, but of particular relevance are inland floodplains which are often affected by development projects. Dams, irrigation systems, and other measures affect both inland and coastal wetlands important for fisheries, and alternative means of managing these systems need to be developed, along with guidelines to assessment of potential impacts on both environmental and socio-economic grounds.

\section{Tourism development projects}

2.1 Natural areas -- mountains, rivers, wetlands, forests, savannas, coral reefs, deserts, beaches -- are major attractions for tourists. Tourism can bring numerous socio-economic benefits to a country, in terms of creating local employment, stimulating local economies, generating foreign exchange, stimulating improvements to local transportation infrastructure, and creating recreational facilities. Positive effects on the environment often derive from these socio-economic benefits. Such positive effects may include:

- encouraging productive use for conservation objectives of lands which are marginal for agriculture, thereby enabling large tracts of land to remain covered in natural vegetation

- promoting conservation action by convincing government officials and the general public of the importance of natural areas for generating income from tourism

- increasing awareness amongst local communities of the benefits from conservation, including the economic opportunities it can generate

- stimulating investments in infrastructure and effective management of natural areas 
2.2 These benefits can provide incentives for effective management of the natural areas which are tourist destinations, which in turn enhances the quality of the natural resources that attract tourists. Properly planned and managed tourism in natural areas is both non-polluting and renewable, and numerous examples exist where tourism has provided powerful incentives for conserving biological resources.

2.3 However, biological resources can also be damaged by inappropriate tourism developments. McNeely and Thorsell (1987) have outlined the positive and negative impacts that tourism can have on such resources and recommend that the guiding principle for tourism development in natural areas should be to manage the natural and human resources so as to maximize visitor enjoyment while minimizing negative impacts of tourism development.

2.4 Four general principles are relevant for linking investments in tourism with conservation of ESAs:

- Planning for tourism development must be integrated with other planning initiatives, particularly in national parks and other natural areas which are potential tourist destinations.

- Tourism authorities working with protected area managers should determine the level of visitor use an area can accommodate with high levels of satisfaction for visitors and few negative impacts on the environment (the carrying capacity), and ensure that this level is not exceeded.

- For each major tourist destination based on the attractions of biological diversity, a management plan should be developed to specify objectives for both tourism and resource management and to determine how sufficient income from tourism can be provided to the natural area to provide an incentive for improved management.

- National policy should require environmental impact assessments (EIA) for all tourism development projects or programs, and specify the ways and means that the tourism development can provide economic benefits to both the local people and the natural areas which are the primary toprist destinations.

2.5 In short, tourism and conservation of ESAs can be natural partners, and each can benefit from the other if both are properly managed. Sufficient resources must be devoted to managing the natural areas, but it is often difficult to convince the governments who are responsible for budgets to allocate sufficient funds for this purpose. It is in the interest of both tourism and conservation that governments be so convinced. 


\section{Agricultural development projects}

3.1 In addition to the water resource management benefits of ESAs, other positive linkages can also be formed. For example, good soil protection by natural vegetation cover and leaf litter can preserve the productive capacity of the reserve itself, prevent dangerous landslides, safeguard coastlines and riverbanks, and prevent the destruction of coral reefs and freshwater and coastal fisheries by siltation.

3.2 Linkages between conservation and agriculture are also important in industrialized countries. Under regulations adopted by the European Community, EC Governments may define certain areas of the farmed countryside as "Ecologically Sensitive Areas." Such areas are important in environmental terms, and their continued environmental protection depends upon the survival of the traditional forms of farming which give rise to their environmental qualities. Within ESAs, farmers are paid grants to encourage them to continue to farm in a traditional way; ESA payments, therefore, can involve limitations on the amount of fertilizer which can be used, restrictions on changes of agricultural land use and controls over the dates at which meadows are cut for hay; they may also include positive payments to encourage practical conservation, such as woodland management or the restoration of archaeological features.

3.3 A group of US-based NGOs called the "Committee on Agricultural Sustainability for Developing Countries" (CASDC) has suggested a series of criteria for developing sustainable farming systems. Such systems are required if pressures on marginal agricultural lands are to be reduced, thereby enabling such lands (which are often ESAs) to be devoted to conserving natural ecosystems and the benefits they provide. Sustainable farming systems:

a) Maintain and improve soil productivity, quality, and tilth.

b) Augment the potential for achieving the highest possible efficiency in the use and conservation of basic farm resources (soil, water, sunlight, energy, and farmers' time).

c) Incorporate as much biological interaction as possible, including such processes as mulching, the use of nitrogen-fixing plants, the use of agroforestry techniques, and the use of inter-cropping and crop rotations to control pests and weeds.

d) Minimize the use of external inputs which damage the environment and endanger human heal th (some chemical fertilizers; non-selective pesticides and herbicides; and some forms of energy), maximizing instead the use of available, affordable, renewable, and environmentally benign inputs. 
e) Avoid the contamination of groundwater by using only those fertilizers, pesticides and herbicides that do not penetrate below the plants' growing zone and then only in controlled doses.

f) Meet the needs of farm families for energy to work their land, cook, and heat from readily available and affordable energy sources.

g) Meet the needs of farm families for cash income, including from off-farm sources.

h) Are adaptive, so that even as society evolves and communities change, they will strengthen communal cooperation, protect rural survival systems, through community support and sharing allow farm families to keep going in difficult times (famine, drought, and natural or political disasters), and make possible effective local management of community-controlled common property resources (ponds, woodlots, grazing lands, irrigation systems) in ways that permit equitable sharing of benefits.

3.4 Many of the conventional agricultural, water resources development, and forestry projects of the Bank can contribute to the conservation of ESAs by focusing attention on linkages between the ESA and the surrounding lands. To reduce inappropriate pressures on ESAs, the basic criteria of sustainability must be developed and applied to all kinds of farming systems, from the intensive mono-cropping systems to animal husbandry to agroforestry to the vast numbers of mixed systems used by small farmers throughout the region. Therefore, Bank projects in agriculture need to support work on the continuing evolution of the concepts and practices of sustainability, provide encouragement and incentives for the adoption of sustainable agricultural systems (many of which are discussed in McNeely, 1988), and ensure that farmers receive their fair share of the benefits from conserving ESAs.

\section{Linkages with other sectors}

4.1 Other types of projects for which such considerations can be developed include livestock development, cottage industries, aqua-culture, land classification and titling, reforestation, rangeland management, and mangrove management. While some guidelines will be common to all types of project, others win be specific to certain sectors (such as aqua-culture, forestry, or livestock development). For each type of project, guidelines should be developed for application in the design and implementation of the project. Such guidelines should not focus simply on mitigation, but be far more positive in linking development with conservation by showing the mutual benefits that can follow from enhanced consideration of how conservation can support development. 


\section{MINIMUM QUALITY STANDARDS FOR ECOLOGICALLY SENSITTVE AREAS}

\section{General considerations}

1.1 Protected ESAs will succeed in realizing their conservation objectives only to the extent that the areas themselves are effectively managed, and to the extent that the management of the land surrounding them is compatible with the objectives of the protected areas. IUCN has conducted considerable work in this field (see for example Kelleher and Kenchington, 1990; MacKinnon et al., 1985; Oldfield, 1988; Poore, 1992; Poore and Sayer, 1987), which can provide the basis for developing such quality standards. General considerations which need to be incorporated in development projects include:

a) The acceptance of protection depends on putting a sufficient economic value on natural resources and biological diversity and, often, on demonstrating that such areas bring a positive benefit to the local communities around them. Examples may be provided by the role of ESAs as sources of water and products, their maintenance of regional climatic conditions, and their support for tourism.

b) Each ESA, or regional set of ESAs, should have a management plan which establishes the objectives of management, the obstacles to achieving the objectives, the steps required to overcome the obstacles, the resources required, and the costs and benefits of achieving the objectives.

c) Management of an ESA and that of the adjacent land must be planned together, since few protected areas are self-contained entities. The establishment of "buffer zones" (better referred to as "zones of influence") in which human activities including uses of natural resources in adjacent land are compatible with the conservation of natural ecosystems within protected areas, are often vital to the integrity of the latter.

d) The management context and likely ecological resilience of the area in the face of climatic trends and human pressures need critical review, taking into account the likely trend in human numbers in the area in question.

e) Certain "keystone" and critical species will be used as diagnostic indicators of the adequacy of the protected area system, it being assumed that if habitats capable of assuring the survival of viable populations of these are protected, the lesser known species will also be safeguarded. 
f) A conscious relationship needs to be established between in situ and ex situ approaches to conservation and these methods need to be integrated into over-all regional development; the potential contribution of the general managed landscape to conserving biological diversity should not be under-estimated.

g) The national infrastructure needs to be so designed as to ensure that the protected area system designed to manage ESAs is properly evaluated as a national asset and that adequate resources are deployed in its management.

h) The project must gather baseline data on key ecological, economic and social parameters, so that its long-term effects can be monitored.

i) A major effort is needed to raise public consciousness, enlist the aid of professionals in the field (e.g. in universities, museums and professional networks), and educate local communities about the value of the ESA to the region.

\section{Economic factors}

2.1 Decisions about the identification and management of ESAs, including consideration of alternative land uses, must be based on analysis of costs and benefits, and their distribution. Realizing that change is a constant factor in land use, these economic factors require continual review. It is apparent, then, that economics must be an important foundation of all programs for enhancing the contributions of ESAs to society.

2.2 As a basis for applying economic incentives and calculating benefits and costs of various management options for ESAs, governments need to estimate the economic contribution that ESAs make to the national economy. This requires:

- ensuring that national accounting systems make explicit the trade-offs and value judgements regarding impacts on biological resources that may not be measured in monetary terms

- conducting research on methodologies for assessing the cross-sectoral impacts -- positive and negative -- of resource utilization

- collecting information on the physical properties of resources in specific environments and for specific uses

- developing methodologies for assigning values to non-marketed biological resources, appropriate to the needs of the country 
- estimating the economic productivity of various ecosystems, with various types of inputs

2.3 The sustainable levels of production of economic benefits from ESAs -including goods such as fish, timber, wildlife, and medicinal plants, and services such as supply of clean water, tourism, and recreation -- should be estimated, and demands upon benefits planned within those limits. This should be reflected in the prices of forest products and other biological resources.

2.4 The review and formulation of all national policies which have a direct or indirect bearing upon ESAs and the biological resources they contain must therefore:

- estimate the relevant benefits which ESAs can produce

- treat ESAs as reservoirs of capital resources and invest accordingly in preventing the depletion of their productivity

- ensure that the objectives of sustainable utilization are met

- address the basic needs of the local people who depend on the ESAs for their continued prosperity

\section{National policies for managing ESAs}

3.1 The incentives which are required to bring the benefits of ESAs to the community require commensurate policies at the national level. A national or regional conservation strategy can be an effective means of reviewing such policies, and determining what shifts are required to achieve national objectives for conserving the productivity of biological resources. Major policy components of the required integrated action might include the following considerations:

a) Sufficient data needs to be compiled from a wide range of sources to enable ESAs to be identified objectively, and to help define the most appropriate management regimes for these areas.

b) The many economic and financial benefits of integrated rural development linked with conservation of ESAs and the biological resources they contain need to be quantified and brought to the attention of policy makers.

c) Both conflicts and potential for cooperation between the various activities of agriculture, fisheries, forestry, conservation and rehabilitation need to be identified in integrated plans and programs. 
d) Institutional reform and improvement is often a prerequisite to good design and implementation of integrated sectoral development plans and programs.

e) Legislation consonant with the socio-economic patterns of the target group and the natural resource needs to be formulated, both to institute disincentives and to ensure that incentives carry the power of law.

f) Policies and legislation in other sectors need to be reviewed for possible application to conservation of biological resources and community involvement in such work.

g) Effective incentives need to be devised to accelerate integrated development in and around ESAs, aimed at narrowing any gap between what the individual sees as an investment benefit and what the government considers to be in the national interest.

h) The rural population needs to be involved in the design and follow-up of plans and projects regarding ESAs, not simply their implementation.

3.2 Systems of incentives for improving the contribution of ESAs to rural development can be designed in a large number of ways, and numerous options exist for coordinating these incentives with other national policy objectives. In designing systems of incentives, governments should compare several options, with estimated costs and benefits, for each of the various national objectives being addressed. Systems of incentives need to be supported by suitable machinery for implementing the system, including regulation, enforcement, monitoring, and feedback.

3.3 All government sectors which depend on the productivity of ESAs should design policies to encourage the sustainable use of these resource systems, possibly as part of the process of preparing a national conservation strategy. In addition, other sectors which have major impacts on ESAs, such as transport, highways, and the military, should ensure that their policies do not unnecessarily deplete biological diversity.

3.4 Coordination and control of natural resource use in and around ESAs, in particular torintroduce systems of incentives which involve several sectors, may require the creation of new agencies with wide-ranging authority over certain aspects of the operations of implementing ministries within a particular region.

3.5 Based on the best available information, governments should establish national objectives for the management of ESAs. Drawing on the latest advances in conservation biology, governments need to state, as a matter of public record, what proportion of the current land and water area is intended to be legally 
protected for conserving biological resources. Such policy objectives can often be incorporated as part of a national protected area system plan or a national conservation strategy; on the basis of such national objectives, governments can measure the costs and benefits of implementing conservation programs effectively.

\section{Data needs}

4.1 In order to identify ESAs and to develop informed policies on their management, governments should build the capacity to assess the status, trends, and utility of their biological resources. This capacity should include:

a) National compilations of the flora and fauna (at least higher plants and vertebrates) contained within the nation, in addition to the more usual assessment of stocks of timber, fish, and minerals.

b) Where these compilations do not yet exist, development projects might require that rapid appraisal methods be employed -- perhaps through the use of indicator species which can provide the optimal return on investment of field time -- to ensure that biological resources are being given an appropriate level of priority.

c) Institutionalized biological surveys, perhaps carried out by university departments of biology, to determine what species occur where and in what numbers, and how these parameters change over time.

d) A national program for monitoring the status and trends of biological resources, linked to international systems such as UNEP's Global Environmental Monitoring System and the World Conservation Monitoring Centre.

e) Regular publication of the available information on status and trends of biological resources, and the various forces which are affecting these trends.

4.2 These efforts will help governments to recognize the consequences of their development activities on the biological resources of the nation, and help identify external effects of development projects on biological resources. However, in-depth assessments are time-consuming, and action should not be delayed until "all" the information is available; instead, some rapid initial assessments need to be done. Development assistance agencies may be willing to assist in such efforts. 


\section{Policies on mitigating measures}

5.1 ESAs, by definition, make their most important contributions to sustaining society by remaining relatively unaltered by human action; the goods and services they provide depend on natural ecological processes, so any forms of development should be aimed at enhancing rather than reducing their natural productivity.

5.2 In cases where objective and competent analysis dictates that public works are required in or near an ESA, environmental impact assessments should be conducted to ensure that the intrusion is made with the minimum detrimental impact on the natural systems in the ESA, and that appropriate mitigating measures are incorporated in the project. An independent decision-making process which has the confidence of the public may be required to ensure that all factors have been given sufficient consideration.

5.3 Since public works in or near an ESA can significantly increase the value of the ESA (for example, through maintaining low sedimentation rates in reservoirs), sufficient investments should be made in improving the management of the ESA so that it can make the most productive contribution. This may require measures to share the costs of improved management on a sustained basis.

5.4 In some cases, where a development project must intrude on an ESA, equivalent areas may be added to other parts of the ESA, or the value of the ESA lost to the project can be invested in other parts of the national ESA system. In this regard, full consideration should be given toward enhancing investments in ESAs which have been degraded through inappropriate uses.

5.5 Any mitigating measures which are proposed should be incorporated in the management plan for the ESA, and contribute to regional land-use objectives. 


\section{CONCLUSIONS}

The governments of many of the countries of Africa have recognized the importance of Ecologically Sensitive Areas to their development programs, even if they have not used this exact term. However, few nations have been able to invest sufficiently in a systematic approach to designating and managing their ESAs, nor in conducting the economic analysis which would demonstrate the value of such areas to national development.

ESAs are important for social, economic, political, and ethical reasons, and they can make important contributions to sectors ranging from forestry to tourism to rural development. However, many ESAs are being abused rather than nurtured, and a number of general policy changes are required to enable ESAs to be identified, and for the most appropriate management regimes to be implemented.

Each country will have its own particular opportunities and constraints and no set of guidelines or criteria will automatically provide the right answers. Each country will need to design its own approaches to ESAs, and the Bank should stand prepared to provide whatever assistance might be requested. 


\section{REFERENCES}

Dugan, Patrick J. 1990. Wetland Conservation: A review of current issues and required action. IUCN, Gland, Switzerland. 96pp.

Eagles, Paul F.J. 1984. The Planning and Management of Environmentally Sensitive Areas. Longman, London and New York. 160pp.

IUCN. 1980. World Conservation Strategy: Living Resource Conservation for Sustainable Development. IUCN UNEP-WWF, Gland. 44pp.

IUCN. 1987. Action Strategy for Protected Areas in the Afrotropical Realm. IUCN, Gland. 51pp.

IUCN. 1990. 1990 United Nations List of National Parks and Protected Areas. IUCN, Gland, Switzerland and Cambridge, UK. 284pp. [Compiled by the World Conservation Monitoring Centre]

IUCN. 1992. IV World Congress on National Parks and Protected Areas, 1992, Caracas, Venezuela. IUCN, Gland, Switzerland.

IUCN/UNEP. 1986. Review of the Protected Areas System in the Afrotropical. IUCN, Gland, Switzerland. 259pp.

IUCN/UNEP /WRI. 1992. Global Biodiversity Strategy: Guidelines for Action to Save,Study and Use Earth's Biotic Wealth Sustainably and Equitably. World Resources Institute, Washington, DC, USA. 250pp.

Kelleher, Graeme and Richard Kenchington. 1990. Guidelines for Establishing Marine Protected Areas. Great Barrier Reef Marine Park Authority/IUCN Commission on National Parks and Protected Areas. 64pp.

Lusigi, Walter J. 1992. Managing Protected Areas in Africa. UNESCO - World Heritage Fund, Paris, France. 200pp.

MacKinnon, J.R., K. MacKinnon, G. Child, and J. Thorsell. 1986. Managing Protected Areas in the Tropics. IUCN, Gland. 295pp.

McNeely, Jeffrey A. 1988. Economics and Biological Diversity: Developing and Using Economic Incentives to Conserve Biological Diversity. IUCN, Gland, Switzerland. $x v+200 p p$.

McNeely, J.A. and K.R. Miller (eds.). 1984. National Parks, Conservation, and Development: The Role of Protected Areas in Sustaining Society. Smithsonian Institution Press, Washington, D.C. 838pp.

McNeely, J.A. and J.W. Thorsell. 1987. Guidelines for Development of Terrestrial and Marine National Parks for Tourism and Travel. World Tourism Organization, Madrid. 29pp.

McNeely, Jeffrey A., Kenton R. Miller, Walter V. Reid, Russell A. Mittermeier and Timothy B. Werner. 1990. Conserving the World's Biological Diversity. IUCN, Gland, Switzerland; WRI, CI, WWF-US, and the World Bank, Washington, D.C. 193pp.

Nelson, J.G. et al. 1988. The ABC resource survey method, the ESA concept and comprehensive land use planning and management pp. 143-175 in Moss, Michael R. (ed.). Landscape Ecology and Management. Polyscience Publications Inc., Montreal, Canada. 
Oldfield, Sara. 1988. Buffer Zone Management in Tropical Moist Forests. IUCN Tropical Forest Paper 5:1-49.

Poore, Duncan (Ed.). 1992. Guidelines for Mountain Protected Areas. IUCN, Gland, Switzerland and Cambridge, UK. 56pp.

Poore, Duncan, and J. Sayer. 1987. The Management of Tropical Moist Forest Lands: Ecological Guidelines. IUCN, Gland. 63pp.

Siegfried, W.R. and B.R. Davies. 1982. Conservation of Ecosystems: Theory and Practice. SANSP 61:1-97.

Stuart, Simon N. and Richard J. Adams. 1990. Biodiversity in Sub-saharan Africa and its Islands: Conservation management and sustainable use. Occasional Papers of the IUCN Species Survival Commission No. 6. IUCN, Gland Switzerland. 242pp.

Usher, Michael B. 1986. Wildlife Conservation Evaluation. Chapman and Hall, London. 394pp.

WCED (World Commission on Environment and Development). 1987. Our Common Future. Oxford University Press, Oxford, UK.

WCMC. 1992. Protected Areas of the World: A review of national systems. Volume 3: Afrotropical. IUCN, Gland, Switzerland and Cambridge, UK. xxii + 360pp. [Compiled by the World Conservation Monitoring Centre]

WCMC. 1992. Global Biodiversity: Status of the Earth's living resources. Chapman and Hall, London. $\mathrm{xx}+594 \mathrm{pp}$.

World Bank. 1986. Wildlands: Their Protection and Management in Economic Development. World Bank, Washington, D.C. 220pp. 
OPERATIONAL POLICY NOTE NO. 11.02

\section{WILDLANDS: THEIR PROTECTION AND MANAGEMENT IN ECONOMIC DEVELOPMENT}

Table of Contents

1. INTRODUCTION .................... xlii

2. JUSTIFICATION .................... xlii

2.1 Biological Diversity . . . . . . . . . . . . . . . xliii

2.2 Environmental Services ................... xliii

2.3 Wildlands of Special Concern . . . . . . . . . . . x xliv

3. THE BANK'S INVOLVEMENT TO DATE ........... xliv

3.1 Existing Record . . . . . . . . . . . . . . . xliv

3.2 Lessons Learned . . . . . . . . . . . . . . . . . . . xlvi

4 POLICY GUIDANCE $\ldots \ldots \ldots \ldots \ldots \ldots \ldots \ldots$ xlvii

4.1 Types of Projects Needing Wildland Management

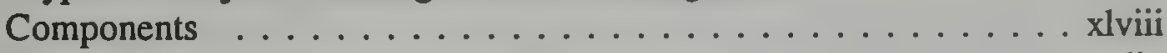

4.2 Types of Wildland Management Components ........... xlix

5 DESIGN OF WILDLAND MANAGEMENT AREAS $\ldots \ldots \ldots \ldots$ li

5.1 Design Considerations . . . . . . . . . . . . . . i i

5.2 Management Categories ........................ lii

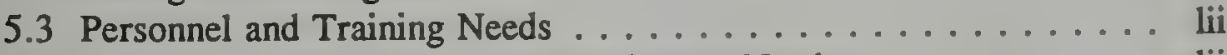

5.4 Equipment, Infrastructure, and Budgetary Needs ......... lii

5.5 Management Plans . . . . . . . . . . . . . . liv

5.6 Legal Considerations .................. liv

\section{ANNEXES}

1 Categories of Wildland Management .............. Iv

2 Some Tropical Wildlands of Special Concern ........... lvii

3 The Project Cycle ..................... lix

4 Physical Inputs Required in Most WMAs . . . . . . . . . . . Ixi

5 Wildland Survey and Management Form .......... Ixii 


\section{INTRODUCTION}

1. The maintenance of specific natural land and water areas in a state virtually unmodified by human activity, hereafter termed wildland management, is an important subset of the broad environmental concerns addressed in OMS 2.36, "Environmental Aspects of Bank Work". The conversion of wildlands to more intensive land and water uses (through land clearing, inundation, plantations, or other means) ${ }^{1}$ continues to meet important development objectives, and is an element of certain World Banksupported projects. At the same time, wildlands are rapidly diminishing in many Bank member countries. The remaining wildlands can often contribute significantly to economic development, particularly in the longer term, when maintained in their natural state. The Bank's policy therefore is to seek a balance between preserving the environmental values of the world's more important remaining wildlands, and converting some of them to more intensive, shorter term human uses.

2. The Bank already has considerable experience of wildland management in Banksupported projects. This OPN codifies existing practices and provides operational guidance concerning conservation of wildlands. ${ }^{2}$ For a more detailed discussion of wildland management, see the Bank's Technical Paper: Wildlands: Their Protection and Management in Economic Development $t^{3}$ which amplifies each section of this OPN. The Office of Environmental and Scientific Affairs in the Projects Policy Department (PPDES) is available to advise and assist staff on issues of wildland management.

\section{JUSTIFICATION}

3. There are two principal justifications for wildland management. First, wildlands serve to maintain biological diversity (i.e., the full range of the world's biota).

1 Conversion here applies to permanent fundamental alteration of the natural ecosystem. Temporary modification by such means as highly selective, long rotation logging usually creates fewer relevant effects.

2 Other conservation activities (designed to protect the environment, but not necessarily to preserve biological diversity) are discussed elsewhere, e.g., in the 1978 Forestry Sector Policy Paper.

Available from the Office of Environmental and Scientific Affairs. 
Second, wildlands provide environmental services important to society. In addition, certain wildlands are essential for maintaining the livelihood of tribal peoples, discussed in OMS 2.34.

\subsection{Biological Diversity}

4. Wildland management is necessary to prevent the untimely and often irreversible loss of a large proportion of the world's remaining biota, including the more visible plant and animal species. Because their wildland habitats are today rapidly disappearing, a large and growing number of biotic forms face extinction. Appropriate, low-cost wildland management measures can greatly reduce current extinction rates to much lower (perhaps almost "natural") levels, without slowing the pace of economic progress. By preserving the integrity of the biotic community and its plant and animal species, wildlands are important for the replenishment of surrounding degraded or abandoned areas.

5. Preserving biological diversity is important to development because of the economic potential of species that are currently undiscovered, undervalued, or underutilized. Many previously unknown or obscure, and often threatened, species have turned out to have major economic benefits. But less than 20 per cent of the world's plant and animal (largely invertebrate) species have ever been inventoried, and even fewer screened for possible human uses. They therefore present valuable development opportunities if they are not irreversibly destroyed. In addition, there are important scientific, aesthetic, ethical, and practical reasons to avoid or minimize the extinction of the remaining biotic stock. While some species can be conserved ex situ (such as in zoos or seed banks), wildland management is the only technically and economically feasible means of preserving most of the world's existing biological diversity.

\subsection{Environmental Services}

6. In addition to maintaining biological diversity, many wildlands also perform important "environmental services", such as improving water availability for irrigated agriculture, industry, or human consumption; reducing sedimentation of reservoirs, harbors, and irrigation works; minimizing floods, landslides, and coastal erosion (and possibly droughts in some regions); improving water quality; and providing essential habitat for economically important fishery species. Despite their economic value and importance in meeting human needs, such environmental services are not always accorded adequate attention because they are usually public goods that tend to be poorly understood, undervalued, or even overlooked. When environmental services are lost due to wildland elimination, remedial measures are almost always far more expensive than prior maintenance. While many environmental services can also be maintained by establishing more intensive water and/or land use systems (e.g., biooxidation sewage treatment, tree plantations), wildland management is frequently more cost-effective. 


\subsection{Wildlands of Special Concern}

7. Wildlands of special concern are areas that are recognized to be exceptionally important in conserving biological diversity or perpetuating environmental services. They can be classified into two types. First are wildlands officially designated as protected areas by governments, sometimes in collaboration with the United Nations or the international scientific community. These are National Parks, Biosphere Reserves, World Heritage Natural Sites, Wetlands of International Importance, areas designated for protected status in national conservation strategies or master plans, and similar "wildland management areas" (WMAs), i.e., areas where wildlands are protected and managed to retain a relatively unmodified state (Annex 1).

8. Second are wildlands as yet unprotected by legislation, but recognized by the national and/or international scientific and conservation communities, often in collaboration with the United Nations, as exceptionally endangered ecosystems, known sites of rare or endangered species, or important wildlife breeding, feeding, or staging areas. These include certain types of wildlands that are threatened throughout much of the world, yet are biologically unique, ecologically fragile, or of special importance for local people and environmental services. Wildlands of special concern often occur in tropical forests, Mediterranean-type brushlands, mangrove swamps, coastal marshes, estuaries, sea grass beds, coral reefs, small oceanic islands, and certain tropical freshwater lakes and riverine areas. Within the spectrum of tropical forests, lowland moist or wet forests are the most species-rich and often the most vulnerable. Wildlands of special concern also occur in certain geographical regions (Annex 2) that have been reduced to comparatively small patches and continue to undergo rapid attrition. As a result, these regions harbor some of the most threatened species in the world.

\section{THE BANK'S INVOLVEMENT TO DATE}

\subsection{Existing Record}

9. During the last 15 years, the World Bank Group 4 has assisted with financing of upwards of 40 projects with significant wildland management components. Most of them have involved establishment or strengthening of WMAs. Bank-supported

4 Includes the International Development Association (IDA) and the International Finance Corporatiòn (IFC) 
WMAs include national parks, nature reserves, wildlife sanctuaries, and those forest reserves managed primarily for their watershed or biological values, rather than for wood harvest. Other wildland management components of Bank projects have involved management of wildlife and the humans that utilize it, including anti-poaching measures, management of water flows frorn reservoirs to maintain wildlife habitat, and relocation of certain species. In still other cases, the location of projects has been changed to avoid important wildland areas.

10. Wildland management components have two principal objectives: first, to prevent, minimize, or partially compensate for wildland elimination, thereby conserving biological diversity; second, to preserve or improve the environmental services provided by wildlands, thereby enhancing the project's economic or social benefits. Most Bank-supported projects emphasize one or the other objective, however some Bank projects have wildland components seeking both objectives. ${ }^{3}$

11. Costs of wildland management components in Bank projects have typically been low. They have normally accounted for less than three per cent of total project costs, and in half of the cases for less than one per cent. In many instances, it is difficult to separate out the cost of the wildland component because of its integration with other components.

12. In one case, wildland management was the sole objective, so accounts for 100 per cent of project costs. At the other extreme, a large number of Bank projects have achieved significant wildland management objectives at zero additional cost. For example, manipulation of a hydroelectric project's water release schedule costs little or nothing, even though it provides major downstream benefits for wildlife, as well as for people and cattle.

5 For example, the establishment of the Dumoga-Bone National Park in the Indonesia Irrigation $\mathrm{XV}$ project helps ensure a more reliable water supply while reducing sedimentation of valuable irrigation works; at the same time, it helps ensure that a significant portion of the project area remains in its natural state, despite surrounding developments. 


\section{Ecologically Sensitive Sites in Africa}

13. Wildland management components require additional Bank staff time and can increase project complexity, but they have rarely caused significant delays at any stage of the project cycle. Moreover, the failure to incorporate adequate wildland components can result in much greater delays and complexity later on. Furthermore, the failure to incorporate adequate wildland components can substantially reduce project benefits and might result in project failure. As wildland management components within Bank-supported projects become more routine, the additional staff effort required to manage them successfully is expected to decrease further.

14. The Bank's track record in implementing wildland management components is encouraging. According to project completion reports or environmental post-audits, implementation of only three out of 43 wildland components has been markedly slower than for most other project components. In at least four cases, the wildland component has been imlemented with less difficulty than other project components.

\subsection{Lessons Learned}

15. A number of important lessons have emerged from the Bank's experience with wildland management to date. First, wildland management components should be routinely and systematically incorporated into certain types of Bank projects (outlined in Section 4.1). Up to now, this has not always been done, and some projects which would have benefitted from wildland components have not included them.

16. Second, wildland components should be incorporated as early as possible within the project cycle (Annex 3) to minimize costs and facilitate implementation. While inclusion of wildland components in later stages of the project cycle may at times be necessary because of unforeseen circumstances, it is more effective and less costly to incorporate them as early as possible in the project cycle.

17. Third, meeting wildland management goals requires effective management "on the ground", not simply on paper. Colonists and resource extractive companies have rapidly moved into such "paper parks" (parks existing only on a legal document or map, rather than on the ground) unless they were inaccessible for other reasons. The wildland management objectives have to be translated into specific measures with a budget for their implementation. These measures include hiring and training of personnel, provision of necessary infrastructure and equipment, development of a scientifically sound management plan for each particular wildland, and a policy environment - legal, economic and institutional - which supports the wildland preservation objective. The mere declaration of intent to protect wildlands or wildlife, or even the designation of WMAs on a map, does not ensure effective management unless specific supporting measures are implemented.

18. Fourth, the multiple objectives of wildland management are most successfully attained if the WMA is carefully designed. For example, a WMA cannot preserve biological and genetic diversity, evolutionary processes, and environmental services 
if it is too small. While some Bank-supported WMAs clearly appear sufficiently large to accomplish most or all of their objectives, others are so small that their ability to conserve biological diversity or provide environmental services or other benefits is questionable. Besides size, the specific location and shape of a WMA can be important factors in determining its success. Appropriate WMA design features are best determined for each case by a conservation specialist.

19. Finally, the success of a WMA, as of other project components, is contingent upon government commitment. This, in turn, often depends upon the degree of financial support provided by the Bank. Most of the Bank-supported wildland components have provided some direct support to establishing or strengthening WMAs. However, in some cases, the costs of the WMA establishment were assumed entirely by the Government, and the Bank took no specific measures to ensure the continued availability of such financing. By taking measures to ensure counterpart financing, or by providing the financing itself, the Bank can help ensure the availability of the relatively modest sums necessary for WMA establishment and continuation.

20. Financial support is usually not sufficient, however. It is often also necessary to maintain dialogue with governments, affected local people, and environmental advocates about the importance of conservation and the benefits of WMAs (tourism, watershed protection, etc.) and to include local people in the planning and benefits. Government commitment to the WMA is fostered by such dialogue, by supervision, by monitoring of national legal provisions, and by loan conditionality. In addition, two complementary and parallel activities contribute to WMA success: (1) rural development investments that provide farmers and villagers in the vicinity of the WMA an alternative to further encroachment, and (2) coherent national and sectoral planning and policies that promote wildland conservation.

\section{POLICY GUIDANCE}

21. The Bank's general policy regarding wildlands is to seek to avoid their elimination and rather to assist in their preservation. Specifically, (1) the Bank normally declines to finance projects involving conversion of wildlands of special concern (as defined in Section 2.3), even if this conversion occurred prior to the Bank being invited to consider financing. (2) When wildlands other than those of special concern may becomfe involved, the Bank prefers to site projects on lands already converted (e.g., logged over, abandoned, degraded, or already cultivated areas) sometime in the past, rather than in anticipation of a Bank project. Deviations from this policy must be explicitly justified. (3) Where development of wildlands is justified, then less valuable wildlands should be converted rather than more valuable ones. (4) When significant conversion (e.g., $100 \mathrm{sq.} \mathrm{kms.,} \mathrm{or} \mathrm{a} \mathrm{significant} \mathrm{proportion}$ of the remaining wildland area of a specicfic ecosystem, if smaller) of wildlands is justified, the loss should be compensated by inclusion of wildland management 


\section{Ecologically Sensitive Sites in Africa}

components (see Section 4.2 below) in the project concerned, rather than in some future project. This component should directly support preservation of an ecologically similar area. ${ }^{6}$ This policy pertains to any project in which the Bank is involved, irrespective of whether the Bank is financing the project component that affects wildlands.

22. The success of projects that do not eliminate any wildland often depends on the environmental services provided by wildlands. In such cases, the Bank's policy is to include a project component to conserve the relevant wildland in a WMA, rather than leaving its preservation to chance. In areas without remaining wildlands, alternative conservation measures may be needed to provide similar project benefits. In other cases, where the wildlands do not directly benefit or serve the objectives of the project, the project may be improved by supporting management of wildlands to provide socio-economic benefits in the general project area (see paragraph 6). Projects with wildland management as the sole objective should also be encouraged.

\subsection{Types of Projects Needing Wildland Management Components}

23. Based upon these criteria, projects with the following aspects should normally contain wildland components:

a. Agriculture and livestock projects involving: wildland clearing, wetland elimination, ${ }^{7}$ wildland inundation for irrigation storage reservoirs; watershed protection for irrigation; displacement of wildlife by fences or domestic livestock; fishery projects involving: elimination of important fish nursery, breeding, or feeding sites; overfishing or introduction of ecologically risky

The policy in the 1978 Forestry Sector Policy Paper states "... in countries where there are no adequate natural resource conservation programs, the Bank will not support projects that might result in disintegration of a habitat not elsewhere represented in the country and not under suitable protection (as in national parks and wildlife reserves)."

7 Wetlands (such as ponds, marshes, swamps, flood plain forests, estuaries, mangroves) can be eliminated inadvertently through water diversions upstream or deliberately through drainage, diking, or filling.

exotic species within aquatic wildlands; forestry projects involving: access roads, clear-felling or other intensive logging of wildlands, wildland elimination. ${ }^{8}$ 
b. Transportation projects involving: construction of highways, rural roads, railways, or canals which penetrate wildlands, thus easing access and facilitating spontaneous settlement; channelization of rivers for fluvial navigation; dredging and filling of coastal wetlands for ports projects.

c. Hydro projects involving: large-scale water development, including reservoir, power, and water diversion schemes; inundation or other major transformation of aquatic or terrestrial wildlands; watershed protection for enhanced power output; construction of power transmission corridors. ${ }^{9}$

d. Industry projects involving: chemical and thermal pollution which may damage wildlands ${ }^{10}$; wildland loss from large-scale mining; wildland conversion for industrial fuels or feedstocks.

\subsection{Types of Wildland Management Components}

24. The most effective type of wildland management component is support for the conservation of ecologically similar wildlands in one or more WMAs. ${ }^{11}$ In cases where a WMA already exists in the same type of ecosystem that is to be converted by a Bank-supported project, it may be preferable, for administrative or biological conservation $^{12}$ reasons, to enlarge the existing WMA, rather than to establish a new one. The government's wildland agencies, local university wildlife departments, and various international organizations can often advise in such judgements.

$8 \quad$ Plantations of fast-growing tree species are often an important complement to more direct wildland management activities by reducing the economic pressures for cutting the remaining forest wildland. They should be sited preferentially on already deforested land. Reforestation and land rehabilitation are covered in the 1978 Forestry Sector Policy Paper.

${ }^{9} \&{ }^{10}$ Industrial pollution control is discussed in the Bank's Environmental Guidelines available from PPDES.

1 See Section 5 for technical guidance on establishing a WMA.

12 Biological conservation is usually more effective in one large WMA than in several small ones comprising the same total size and encompassing the same types of natural habitats. 
25. A wildland management component could also involve the creation of wildlife habitat, in addition to or rather than preservation of already existing habitat. For example, marginal land on the fringes of irrigation projects could be converted to wildlife reserves by taking advantage of the water supply created by the projects. Natural depressions or seasonal swamps could be exploited by diverting water from the canal systems (probably a very small part of the total supply). Such reserves attract significant numbers of migratory and residential waterfowl with minimal additional project costs and land. ${ }^{13}$

26. A useful option is to improve the quality of management of existing WMAs. Many WMAs in Bank member countries receive insufficient on-the-ground management, due to lack of adequately paid staff, training, staff housing, other infrastructure, equipment, spare parts, fuel, or a well-developed management plan through which efficient resource allocation decisions can be made. Small components can often help correct these deficiencies. In countries where effective management is clearly lacking, it is generally preferable to improve the management of existing WMAs than to create new units "on paper", thereby further over-extending the limited capabilities of the responsible agencies. Whenever a new WMA is established as a project component, provisions are needed to ensure effective management. Since many wildland agencies (e.g., departments of national parks or wildlife) are not as operationally effective as necessary, institutional strengthening (particularly support for training) should be an important element of Bank-supported wildland management components.

27. The establishment or strengthening of WMAs is particularly effective when the Government includes these wildland areas in a national conservation or land use plan. A growing number of Bank member governments have undertaken some type of systematic land use planning for wildland management. Such planning can take various forms, ranging from "master plans" for a system of national parks and other WMAs, to "National Conservation Strategies" which address wildland management as only one component of a broad range of natural resource planning concerns, and in which policy intervention such as economic incentives are used to influence resource utilization. Bank assistance with such planning efforts greatly strengthens wildland management at the national level. When member governments agree to develop appropriate land use plans, it is important for the Bank to refrain from supporting projects which involve eliminating wildlands and run counter to these plans.

The Wildfowl Trust, Slimbridge, England, has set up such reserves on 5-8 sq. km. 
28. In those relatively few Borrower countries in which wildland elimination pressures are still minor, ${ }^{14}$ the requirement of a compensatory wildland component can be interpreted more flexibly to involve measures other then the establishment or strengthening of one or more WMAs. Such alternative options include careful project siting to avoid converting the more environmentally sensitive wildlands, support for research on and management of particularly sensitive species, support for land use planning efforts, or institutional strengthening of the government's wildland management agency, and training in ecology, biological conservation, and wildland management.

\section{DESIGN OF WILDLAND MANAGEMENT AREAS}

\subsection{Design Considerations}

29. WMA design features include size, shape and siting. Because an optimal design may vary greatly in different ecosystems, it is best determined in each case by a conservation specialist.

30. The size of a compensatory WMA should be sufficient to maintain the biological diversity or other important values present in the area to be converted. A WMA which is large enough to encompass a viable population of the largest local predator (e.g., eagle, tiger), or the seasonal territories and migration routes of the largest local herbivore, will most likely preserve all other pertinent ecological values. These objectives would most likely be achieved in a WMA larger than 1,000 sq. kms. Many values are conserved in moist forest WMAs of $500 \mathrm{sq}$. kms, although possibly not all in perpetuity. Interim WMAs of less than $100 \mathrm{sq}$. $\mathrm{kms}$ can be useful short-term expedients for subsequent expansion into surrounding degraded areas. In general, the larger the WMA, the greater the number of ecological interdependencies and gene pools that will be preserved. Both are necessary to a healthy and self-perpetuating ecosystem. It is recognized that conflicting pressures for more intensive land use often make the establishment of large WMAs difficult. In any case, compensatory WMAs should be no smaller than the wildland area converted by the project.

14 Wildland elimination pressure may still be minor because of low human population densities and growth rates, little economic demand for agricultural land, timber, or other resources, or because a substantial proportion of each remaining wildland ecosystem in a country has been set aside in WMAs which receive good on-the-ground protection and have strong policy support from the Government. 
31. The optimal shape of a WMA will depend upon its objectives. A more circular shape may preserve more biological diversity than other shapes of the same area. Shape is also determined by the location of centres of endemism and other wildlife resources. Boundaries are more effective when they coincide with natural surficial features, such as a river or watershed.

32. To ensure that the compensatory WMA is ecologically similar to the area to be converted, it is obviously necessary to site the WMA in the same ecosystem as the area to be converted. Moreover, siting the WMA some distance away from the converted area (separated by a managed buffer zone for example) helps reduce pressures for encroachment upon the WMA from people living in the converted area.

\subsection{Management Categories}

33. A variety of different use related categories can be used in establishing WMAs. The choice of category depends upon the particular objectives being accorded priority for management. The categories listed in Annex 1 indicate the variety of WMAs appropriate under different circumstances.

\subsection{Personnel and Training Needs}

34. The need for well-trained personnel in the proper management of WMAs cannot be overemphasized. Without adequate numbers of such trained people, WMAs cannot effectively serve their intended national or societal functions. Bank-supported wildland project components should therefore provide for staffing levels and training activities that ensure competent management of WMAs. The appropriate number and types of WMA personnel depend upon the category of WMA, its size, and its intensity of management. The minimum adequate permanent staff size for a "modest to average" WMA is usually about eight.

\subsection{Equipment, Infrastructure, and Budgetary Needs}

35. Designation of WMAs on a map in no way ensures that they will be managed to provide their greatest possible benefits to society. Effective on-the-ground management requires a variety of physical inputs. In Bank-supported WMAs, efforts should be made to ensure that these inputs are provided as a project component in adequate supply and on a timely basis. Annex 4 contains a basic checklist of the physical inputs that are typically needed for effective WMA management. Some types of WMAs will require a variety of additional inputs, according to specific management objectives.

36. The budgetary requirements for establishing and operating WMAs will vary according to size and the amounts of needed infrastructure, equipment, and personnel. The comparatively large (3,200 sq. kms.) Dumoga-Bone National Park, financed by the Indonesia Irrigation XV Project, cost roughly US\$ 1 million for establishment and 
initial operating costs; most smaller WMAs can be expected to cost considerably less.

37. In some instances, establishment or enlargement of WMAs may require additional funds for purchasing land from private or tribal owners. It may at times also be necessary to resettle and compensate people living within the boundaries of a newly-established WMA. ${ }^{15}$ Usually, however, WMAs are established on wholly government-owned properties on which people have not settled.

38. The largest recurrent cost of WMAs is usually staff salaries. It is important to maintain salaries at levels that encourage high productivity and a degree of permanence, and discourage corruption. ${ }^{16}$ Spare parts for machinery, while usually a relatively small budget item, are also a vital recurrent expenditure. Without a reliable supply of spare parts for often remote WMA areas, necessary equipment will often lie idle or may become cannibalized to provide spare parts. In some cases, salaries, spare parts, fuel, and other recurrent costs can be fully or partly met by fees collected from tourists, persons engaged in some form of harvesting, or scientific researchers. ${ }^{17}$ Otherwise, small annual outlays from the national or other government budget will be needed.

is See OMS 2.33 for guidelines regarding involuntary resettlement and OMS 2.34 for guidelines regarding tribal people in Bank-financed projects. In many cases, indigenous hunter-gatherer societies are as much a part of the "natural" environment as the wildlife, and can safely remain in the park as caretakers as long as traditional ways of life are continued.

16 High productivity also depends upon these important components: 1) environmental education for an understanding of the importance of the WMA; 2) pride in the WMA and the role of those who protect and support it; and 3) self-interest through some direct accrual of benefits of the WMA (aesthetic, recreational, moral, etc., as well as economic).

17 The proportion of recurrent costs that can be recovered in this manner varies greatly in different WMAs, from 0 to 100 per cent. 


\subsection{Management Plans}

39. Wildland management areas typically need well-developed management plans to ensure efficient allocation of the scarce financial and skilled human resources devoted to their management. A management plan is a written document which guides and controls the use of the resources of a WMA and directs the design of subsequent programs of management and development. A thorough management plan will:

(a) Describe the physical, biological, social, and cultural features of the WMA within a national, regional, and local context;

(b) Identify those items of particular concern from which the objectives for managing specific areas of the WMA are derived;

(c) Describe appropriate uses of the entire WMA through zoning; and

(d) List in chronological order the activities to be carried out to realize the proposed management programmes.

40. Preparation and implementation of management plans are carried out by the government wildland agency. Project staff should ensure that Bank-supported WMAs either have adequate management plans or will develop them early in the project. Some parts of a management plan can be completed in a few days, while others may take years to refine. While a longer-term management plan is being developed as soon as possible after loan signing, an "interim management plan" or "operational plan" may be used. PPDES can be of assistance in these matters.

\subsection{Legal Considerations}

41. The success of a WMA may depend upon how its design fits into an overall national legal framework concerning natural resources management in general and wildland management in particular. To maintain their legitimacy in the eyes of policymakers and local populations, WMAs must have a firm legal foundation. National legislation, sometimes accompanied by a specific Presidential designation, is often needed to establish a WMA. Depending upon the particular situation, such legislation needs to establish precise WMA boundaries; specific management zones within the WMA, including buffer zones; a central management authority (at the national or subnational level) with unambiguous responsibilities; and a mechanism to channel local participation in WMA management decisions. Bank staff should ensure that Banksupported WMAs are established and managed within a compatible legal and policy context.

June 2, 1986 


\section{ANNEX I \\ Categories of Wildland Management ${ }^{18}$}

1 Scientific or Strict Nature Reserves represent the most restrictive WMA category, intended to maintain representative samples of natural ecosystems in an undisturbed state for scientific research, environmental monitoring, education, and preservation of biological diversity. Tourism, recreation, and most other human uses are usually not permitted.

2 National Parks are usually relatively large areas where native plant and animal species (and often outstanding geological or other scenic features) are of special interest. Controlled tourism and scientific research are permitted; more intensive human uses usually are not.

3 Natural Monuments are often smaller WMAs intended to protect highly localized species, ecosystems, or geological formations. Tourism and scientific research are permitted to the extent that they are compatible with preservation of the unique natural features.

4 Managed Nature Reserves or Wildlife Sanctuaries protect rare plant or animal species, or large concentrations of resident or migratory wildlife. Manipulation of vegetation and other intensive management may be done to improve the habitat for species of special concern. Tourism, research, and occasionally limited livestock grazing or fuelwood collection are permitted, when these activities are compatible with wildlife management objectives.

5 Tribal Peoples Reserves are relatively unmodified natural areas in which indigenous tribal peoples or vulnerable ethnic minorities (see OMS 2.34) continue to practice traditional, low-intensity forms of land use such as hunting and gathering or nomadic pastoralism. Settlement or potentially disruptive resource utilization by outsiders is not permitted.

6 Protected Landscapes are areas which have often been significantly modified by people, but which still contain important wildland resources. Traditional land uses, including fishing, grazing, and some agriculture, are often permitted to accommodate the needs and interests of local populations. Land use control is often at the local government level.

Recognizing that different countries use different names for various types of WMAs, the standardized system of WMA nomenclature developed by the International Union for Conservation of Nature and Natural Resources (IUCN) is used here to facilitate comparisons and reduce confusion. 


\section{Ecologically Sensitive Sites in Africa}

7 Resource Reserves are "interim" WMAs. They are typically fairly extensive areas which are not yet heavily settled, but which may be under relatively recent pressure for colonization, timber or mineral extraction, or other intensive uses. This WMA category is designed to restrict such uses until a land use plan or other management guide is issued to channel further development in an environmentally suitable manner.

8 Multiple Use Management Areas are intended to allow sustainable production of such economic goods as water for downstream uses; timber (obtained through lowintensity logging); fuelwood; wild fruits, herbs, gums, or other plant products; wildlife; fish; grazing; and outdoor recreation. Included in this category are most "forest reserves" and "protection forests," including those established largely for watershed catchment protection. Within these WMAs, management is primarily oriented to the sustaining of these economic activities, although special zones may also be designated within these areas to achieve more specific conservation objectives, such as preservation of biological diversity. These WMAs are generally large and capable of sustaining these types of economic activities without degradation or elimination of the wildland resource. Generally, these wildland areas do not possess nationally unique or exceptional natural features. 


\section{ANNEX II}

\section{Some Tropical Wildlands of Special Concern ${ }^{29}$}

\section{Eastern Africa}

1 Madagascar: significant proportions of the northern and eastern moist forests.

2 Ethiopia: much of the remaining highland forest.

3 Tanzania: Usambara, Pare, and Uluguru Mountains.

4 Rwanda: mountain forests along the Zaïre and Uganda borders.

5 Kenya: Kakamega, Nandi, and Arabuko-Sokoke forests.

\section{Western Africa}

6 Cameroon: particularly Cameroon Mountain and the moist forested area extending into Gabon, and to the vicinity of the Cross River in southeastern Nigeria, including the Oban Hills.

7 Ivory Coast: southwestern forests (including the Taï forest), and adjacent parts of Liberia and Sierra Leone.

\section{East Asia and Pacific}

8 The Malay Peninsular (including parts of Thailand): Lowland forests, especially along the northwestern and eastern coasts.

9 Indonesia: much of the remaining lowland forests of Kalimantan, Sumatra, Sulawesi (especially the two southern peninsulas), and many smaller islands (e.g., Siberut).

10 Philippines: much lowland forest on all larger islands.

\section{South Asia}

11 Sri Lanka: the coastal hills of the southwest and the Sinharaja forest of the "wet zone."

12 India: most of the forests remaining on the Western Ghats.

13 Burma: the untouched teak forests in the northern regions.

\section{Latin America and Caribbean}

14 Ecuador: lowland coastal forest

15 Mexico: Lacandon forest in Chiapas.

16 Honduras-Nicaragua border: Mosquitia forest.

17 Panama: Darien province.

18 Colombia: the Choco region adjacent to Darien province.

19 Brazil: coastal forests of the "Cocoa Region" in the southeastern extension of Bahia between the coast and $41^{\circ} 30^{\prime} \mathrm{W}$ longitude, and between $13^{\circ}$, and $18^{\circ} 15^{\prime} \mathrm{S}$ latitude, and an outiier near Linhares, Espiritu Santo.

20 Brazil: parts of the eastern and southern Amazon region.

19 This list is by no means to be interpreted as comprehensive. 
Ecologically Sensitive Sites in Africa

\section{Tropical Aquatic Areas}

1 Amazon River and associated wetlands (including varzea forests) (Brazil, Peru, Colombia, Ecuador, and Bolivia.)

2 Orinoco River and Delta (Venezuela and Colombia).

3 Purari River (Papua New Guinea).

4 Musi River (Sumatra, Indonesia).

5 Lake Malawi (Malawi), and other Rift Valley Lakes.

6 Lake Toba (Sumatra, Indonesia).

7 Sudd Swamp (Sudan).

8 Pantanal Swamp (Mato Grosso, Brazil).

9 Lake Atitlan (Guatemala). 


\section{ANNEX III}

\section{The Project Cycle}

Responsibility for implementing wildland management projects or components rests primarily with regional operations staff, with advice and operational support provided by PPDES, as detailed for all environmental work in OMS 2.36. At identification, projects being considered are reviewed by regional staff in conjunction with PPDES to identify, as early as possible, the need to avoid converting a wildland tract or to preserve such a tract as part of the project. To determine whether a proposed project will develop or be in close proximity to ennvironmentally important wildlands, Bank staff can consult those government agencies with jurisdiction over wildland management authority. PPDES maintains contacts with such agencies and will assist upon request. Additional sources of information on ecologically important wildlands are computerized data bases maintained by some non-governmental organizations (NGOs) and several published directories, available from PPDES. In this manner, it will often be possible to learn quickly whether a proposed project site contains existing or proposed WMAs; known endangered species; major wildlife or fish breeding, feeding, or staging areas; important watershed catchments; or living resources of major importance to local people. If none of these mechanisms reveal the existence of ecologically important wildlands in the project area, a brief pre-project field survey is necessary since many important wildlands are not yet identified. This field survey should be undertaken by relevant specialists from the government's environmental ministry, wildlife agency, national university, or similar institution. This brief survey indicates the nature and extent of impacts on critical wildlands that would result from the implementation of the project and puts the information in a national context. The results should be recorded on the form provided in Annex 5.

During preparation, project staff (or their consultants) may assist the Borrower or project sponsor in carrying out the necessary environmental studies, including those pertaining to wildlands. PPDES can recommend consultants or other experts who can identify important wildland areas, carry out necessary field surveys, or help design appropriate wildland management project components. At the completion of any necessary studies, the Project Brief (see OMS 2.13) should highlight whether the project involves the conversion or disintegration of a relatively unmodified ecosysten and include alternative suggestions for achieving the goals of the government. If conversion is justified, the Brief should outline why, together with the wildland management components needed.

As part of appraisal, project staff assess the planned wildland management and other environmental measures, as specified by OMS 2.20. The Staff Appraisal Report specifically describes any planned wildland management measures, including budgets and agency responsibilities. While PPDES is available for consultation and assistance at any stage of the project cycle, it is also responsible for reviewing projects at the Yellow Cover stage (see OMS 2.00). In addition to the Staff Appraisal Report, the 
President's Report (see OMS 3.02) also notes any significant environmental -including wildland management - issues and mitigatory measures. Once wildland measures are identified as necessary, timely action should be ensured by conditionality such as loan effectiveness of disbursement. Since wildland management must be done in perpetuity to be effective, the loan agreement should specify long-term measures which the Borrower has agreed to implement.

Supervision missions should routinely review implementation of the wildland component with the Borrower. Such aspects are handled as for environmental issues in general (see OMS 2.36). Implementation of important wildland components should, as a general principle, be well underway before a project's major land clearing or construction works are allowed to proceed. 


\section{ANNEX IV}

\section{Physical Inputs Required in Most Wildland Management Areas}

a. Headquarters building and guard posts at entry points.

b. Staff housing

c. Visitor information center, including educational and interpretive exhibits where appropriate.

d. Research facilities, including laboratory and housing for scientists.

e. Roads and trails (amount will vary according to intensity of management desired).

f. Fencing and signs, adequate to ensure proper demarcation and to control access.

g. Communications, internal and external to the WMA: radio, walkie-talkies, mail, and telephone (where appropriate).

h. Electricity, gas, or other energy systems.

i. Sewage and waste systems.

j. Four-wheel drive, motor bikes, or other vehicles.

k. Boats, outboard motors, and docking facilities, where needed.

1. Appropriate tools, maintenance equipment, and spare parts.

m. Fuel.

n. Management-oriented publications: maps, species lists, pamphlets for visitors, etc. 


\section{ANNEX V \\ Wildland Survey and Management Form ${ }^{20}$ \\ (Sample only)}

\section{Name of Project:}

Expected Appraisal (or other) Date:
Date of this Survey:
Surveyor:
Affiliation:

Methodology(ies) (circle one):

Site inspection/Library research/Both/Other(specify)

1 Specific subcategory(ies) of ecosystem that proposed project will affect: (e.g., tropical semi-evergreen moist forest, salt-marsh, wet savanna)

2 Important environmental and biological features of ecosystem(s): (e.g., water catchment area for large agricultural valley and habitat for the endangered mountain gorilla)

3 Projected general impact type on ecosystem(s) of proposed project: (e.g., deforestation, flooding, draining)

4 Proportion (\%) of the region's remaining ecosystem(s) (as in \#1 above) to be converted (and/or impacted, if different): (e.g., this project will flood about 10\% of this country's remaining lowland riparian swamp forest.)

5 Estimated annual rates of attrition of affected ecosystem(s) in this country and historical trend of this rate: e.g., The current annual rate of attrition of (semimontane forest) is $3 \%$ a year. This rate was $0.5 \%$ in 1975 and $1 \%$ in 1980.)

Maps and more complete reports used or available can be appended or cited.

20 This type of information is expected as part of identification, and can be used for the project brief. This form can be completed by the government's environmental ministry or wildlife agency, or by the project pre-feasibility team's wildlands specialist. 


\section{SECTION II}

\section{OCCIDENTAL AND CENTRAL AFRICA}

Benin, Cameroon, Central African Republic, Congo, Côte d'Ivoire, Equatorial Guinea, Gabon, Guinea, Togo

\section{ANNOTATED LIST OF SITES}

Within each country, sites are divided into four subsections, according to the degree of protection they appear to enjoy.

INTERNATIONALLY DESIGNATED PROTECTED AREAS These are the World Heritage sites, Biosphere Reserves and Ramsar sites within each country.

NATIONALLY PROTECTED AREAS Excluding those in the above section, these include all nationally designated protected areas having objectives which qualify them for IUCN Management Categories I-VII (see below).

OTHER MANAGED AREAS In this section are other designated sites which have a nature conservation function (including forest reserves and other IUCN Management Category VIII sites), as well as some well managed private reserves.

UNPROTECTED SITES This section includes sites where there is no officially recognised protection status. Three types of site are included: proposed protected areas, where implementation is either being studied or is under way; recommended sites, where protection has been recommended by an individual or group but where implementation is yet to be initiated; and other sensitive sites which have been recognised as valuable wildlands.

In some countries, the political situation may have caused management to lapse, and in these and other cases information on the current status of the site can be hard to obtain. The annotated list is based on the information available.

The protected areas information shown on the maps for each chapter have been classified by management authority; i.e the forestry sector, wildlife sector or additional sector (e.g. Presidential reserve). Information concerning the location of all numbered sites was not available. Hence some sites numbered on the lists do not appear on the maps.

This list has been prepared as a desk study, and is based on available information. It should be laken as a guide rather than a definitive study. 


\section{Information Sources}

The World Conservation Monitoring Centre gathers, analyzes and disseminates information on the status, security and management of the Earth's biological diversity as a service to the international community. The information presented in this publication has been drawn from WCMC's databases and geographical files which have been developed in collaboration with numerous national and international sources. These data, which have been gathered over a number of years, are held within tabular databases, paper files and geographic information systems (GIS) at the Centre. WCMC relies on its own and its sponsors' worldwide network of contacts, as well as published and unpublished literature, to provide accurate information and an efficient service to its users.

The protected areas listings in the country chapters have been downloaded from the WCMC Protected Areas Database which contains over 32,000 records. The WCMC maintains these data in collaboration with the IUCN Commission on National Parks and Protected Areas, the UNESCO Man and the Biosphere Programme, the World Heritage Convention and others. This desk study has concentrated heavily on these data and on the extensive conservation library held at WCMC.

Much of the information WCMC holds has a spatial element and since 1989 WCMC has been operating a GIS. A substantial amount of data on threatened habitats, protected and unprotected sites and other related subjects have now been assembled. The digital spatial data run in parallel with the supporting structured data, and the locational or boundary information shown on the maps within the country chapters are updated as new data are acquired. The spatial data are maintained within the Centre's GIS in ARC/INFO format and are available to all parties concerned with environmental conservation, via the WCMC Biodiversity Map Library (BML). The BML has been designed and implemented to enhance the Centre's information service providing a method for maintaining the environmental data in a structured and easily accessible manner. The information shown on the maps in this book are stored in the BML.

The following text was originally drafied in December 1991 by James Culverwell and Hilary Tye, and updated in 1993 by James Culverwell and Harriet Gillett. Maps were prepared by Mary Edwards. Final copy was prepared by Harriet Gillett with assistance from Mark Lewis. Secretarial support was provided by Veronica Greenwood, with assistance from Deborah Rothera. Clare Billington and Jerry Harrison were responsible for overall coordination. 


\section{BENIN}

\section{INTERNATIONALLY DESIGNATED PROTECTED AREAS}

Pendjari Biosphere Reserve

IUCN Categories II and IX This biosphere reserve of 880,000 ha includes Bouclé de Pendjari National Park (a core area of 275,500ha), Pendjari and Atakora hunting zones and also the Arly Reserves in Burkina Faso. It is part of a larger, international contiguous complex of reserves which totals nearly $4,000,000 \mathrm{ha}$. This relatively flat, low-lying area is important for its wide variety of habitats typical of West African savanna. This is due to its situation at the transition between Sudan and Guinea types of savanna. Gallery forest occurs along rivers. Many West African savanna species occur here, including several threatened animals such as leopard, African wild dog, cheetah, elephant and Nile crocodile. However, fire and gradual climatic desiccation have devastated habitats and severely depleting animal populations, which have also suffered from poaching and increased pressure from cattle grazing. However, the area is now being successfully rehabilitated with the assistance of international aid, and appears to be well managed (S.J.G.Hall, pers.comm., 1993; IUCN/UNEP, 1987; Maché and Touré, 1990).

\section{NATIONALLY PROTECTED AREAS}

\section{Atakora Hunting Zone Pendjari Hunting Zone}

IUCN Categories VIII and IX IUCN Categories VIII and IX These reserves of $122,000 \mathrm{ha}$ and $200,000 \mathrm{ha}$ respectively, are both part of the Pendjari Biosphere Reserve complex, managed for sport hunting as part of a buffer zone to Bouclé de Pendjari National Park. This is part of a larger, international contiguous complex of reserves which totals nearly $4,000,000 \mathrm{ha}$. They support Sudan savanna, interspersed with gallery forest and marshland around pools. The fauna is characteristic of West African savanna and includes buffalo, elephant, hippopotamus and several primate species. Poaching, cattle grazing and habitat degradation are problems (IUCN/UNEP, 1987).

\section{W du Benin National Park}

IUCN Category II

This protected area of 568,000 ha is part of an international park shared with Burkina Faso and Niger, totalling $1,023,000 \mathrm{ha}$ within an international complex of reserves of nearly $4,000,000 \mathrm{ha}$. The complex is an important area for the conservation of West African savanna species. In Benin there are extensive savanna-covered plains with scattered lakes, marshlands and riverine forest, plus part of the Atacora mountains. The international park contains the most important savanna elephant population in West Africa and many other species also occur, including lion, leopard, cheetah, hippopotamus and Nile crocodile. Buffer zones surrounding the park are managed for sport hunting, but poaching remains a problem and there is a need for coordinated policies and anti-poaching measures between the three countries involved. There is also continual human encroachment by subsistence farmers and nomadic pastoralists, resulting in degradation of vegetation and grazing competition with wild ungulates. Staffing is insufficient to prevent habitat destruction. However, this park is also 
included in the habitat rehabilitation scheme centred on Pendjari. Plans to mine phosphates could also affect the park (IUCN/UNEP, 1987; Maché and Toure, 1990; Sinsin and Heymans, 1988).

\section{OTHER MANAGED SITES}

Agoua Classified Forest

Established in 1953 75,300ha.

Agrimey Classified Forest

Established in $1945 ; 2800$ ha

Atcherigbe Classified Forest

Established in 1942; 3150ha

Atlantique Classified Forest

Established in 1953; 900ha

Bassila Classified Forest

Established in 1943; 2500ha

Bellefoungou Classified Forest

Established in 1943; 1300ha

Birni Classified Forest

Established in 1943; 3200ha

Boko Classified Forest

Established in 1952; 300ha

IUCN Category VIII

IUCN Category VIII

Bonou Classified Forest

Established in 1946; 197ha

IUCN Category VIII

IUCN Category VIII

IUCN Category VIII

IUCN Category VIII

IUCN Category VIII

Dan Classified Forest

Established in 1942; 1237ha

IUCN Category VIII

IUCN Category VIII

Dassa-zoume Classified Forest

Established in 1945; 2645ha

IUCN Category VIII

Djigbe Classified Forest

IUCN Category VIII

Established in 1942; 4300ha

IUCN Category VIII

Djona Hunting Zone

IUCN Category VIII

This reserve covers $188,000 \mathrm{ha}$ of Sudan savanna interspersed with gallery forest and marshes around pools. It is on the edge of an international contiguous complex of reserves which totals nearly $4,000,000 \mathrm{ha}$. The fauna includes buffalo, elephant, 
hippopotamus, topi, kob and several primate species. Poaching is a problem and grazing of domestic cattle also occurs (IUCN/UNEP, 1987).

Dogo Classified Forest

Established in 1955; 31,850 ha

IUCN Category VIII

Donga Classified Forest

IUCN Category VIII

Established in 1943; 250ha

Gougoun Classified Forest

$11^{\circ} 35^{\prime} \mathrm{N}, 3^{\circ} 18^{\prime} \mathrm{E}$ (approx.) 1950 73,200ha (Stuart et al., 1990)

Guene Classified Forest

IUCN Category VIII

Established in 1942; 1300ha

Itchede Classified Forest

IUCN Category VIII

Established in 1945; 191 ha

Kétou Classified Forest

7²4'N, 2³3'E (approx.) 1945 11,000ha (Stuart et al., 1990)

Kibibo Classified Forest

IUCN Category VIII

Ko Classified Forest

IUCN Category VIII

L'Albori Supérieur Classified Forest

IUCN Category VIII 256,000 ha

La Lama Nord/La Lama Sud Classified Forests

IUCN Category VIII $6^{\circ} 50^{\prime} \mathrm{N}, 2^{\circ} 13^{\prime} \mathrm{E}$ Established in 1942 , these areas cover 6500 and 9750 ha respectively (Stuart et al., 1990).

La Sota Classified Forest

IUCN Category VIIi

Established in 1947; 53,000ha (Stuart et al., 1990)

Logozohe Classified Forest

IUCN Category VIII

Established in 1942; 1200ha

Mekrou Classified Forest

IUCN Category VIII

Mont Kouffe Classified Forest

IUCN Category VIII $8^{\circ} 45^{\prime} \mathrm{N}, 2^{\circ} 06^{\prime} \mathrm{E}$ Established in 1949 , this area of $180,300 \mathrm{ha}$ is an important central forest reserve, the development of which might involve integrated rural development programmes. Red river hog and Maxwell's duiker occur, as might the bongo, which is currently considered to be extinct in Benin (Stuart et al., 1990). 
Established in 1942; 107,500ha

Ouari Maro Classified Forest

IUCN Category VIII $9^{\circ} 09^{\prime} \mathrm{N}, 2^{\circ} 25^{\prime} \mathrm{E}$ Established in 1946 and covering an area of $107,500 \mathrm{ha}$, this is an important central forest reserve, the development of which might involve integrated rural development programmes. The restricted and possibly endangered red river hog occurs in low densities (Stuart et al., 1990).

Ouedo Classified Forest

Established in 1944; 586ha

IUCN Category VIII

Oueme Boukou Classified Forest

Established in 1954; 20,500ha

IUCN Category VIII

Oueme Supérieur Classified Forest

IUCN Category VIII $9^{\circ} 35^{\prime} \mathrm{N}, 2^{\circ} 30^{\prime} \mathrm{E}$ Established in 1954 , this forest reserve covers $177,542 \mathrm{ha}$. It is an important priority for conservation, the development of which might involve integrated rural development programmes (Stuart et al., 1990).

Ouenou-Benou Classified Forest

Established in 1943; 30,000ha

IUCN Category VIII

Pahou Classified Forest

Established in 1940; 765ha

IUCN Category VIII

Penessoulou Classified Forest

Established in 1942; 5470ha

IUCN Category VIII

Sakarou Classified Forest

Established in 1954; 240ha

Sakete Classified Forest

Established in 1946; 60ha

IUCN Category VIII

Savalou Classified Forest

Established in 1945; 1015ha

IUCN Category VIII

Seme Classified Forest

Established in 1943; 1290ha

IUCN Category VIII

Serou Classified Forest

IUCN Category VIII

Established in 1946; 498ha

Soubroukou Classified Forest

Established in 1946; 84ha 
Tchaourou Classified Forest

Established in 1942; 1100ha

Tchaourou Gokana Classified Forest

Established in 1948; 2000ha

Toui Classified Forest

Established in 1942; 29,030ha

Tozoun Classified Forest

Established in 1942; 66ha

Trois Rivières Classified Forest

Established in 1949; 259,500ha (Stuart et al., 1990)

\section{UNPROTECTED SITES}

\section{Coastal Swamp Forests}

Identified as being of particular biological importance, none are currently protected. The sitatunga may survive (Stuart et al., 1990).

Djessin Biosphere Reserve

10,000 ha

\section{Lake Ahéme}

$6^{\circ} 24^{\prime} \mathrm{N}, 1^{\circ} 59^{\prime} \mathrm{E}$ Surrounded by predominantly freshwater marshes, this lake in the extreme south-west of the country is of importance for waterfowl and waders (Altenburg, 1987).

\section{Lake Nokoué}

$6^{\circ} 25^{\prime} \mathrm{N}, 2^{\circ} 27^{\prime} \mathrm{E}$ Surrounded by brackish freshwater marshes and some mangroves north of Cotonou, this lake is of importance for waders and waterfowl (Altenburg, 1987).

Pobé Forest

Recommended

$7^{\circ} 00^{\prime} \mathrm{N}, 2^{\circ} 42^{\prime} \mathrm{E}$ Situated in the south of the country, this important forest has been severely degraded by timber clearing and exotic plantations (IUCN, 1987; Stuart et al., 1990). 


\section{BENIN - PROTECTED SITES}

National/international designations

Name of area and

map reference (see Fig. 1.1)

Management

area (ha)

75,300

2,800

3,150

900

2,500

1,300

3,200

300

197

1,237

2,645

4,300

31,850

250

73,200

1,300

191

11,000

50

256,000

6,500

9,750

53,000

1,200

9,320

180,300

4,721

107,500

586

20,500

177,542

30,000

765

5,470

240

60
Year

notified

1953

1945

1942

1953

1943

1943

1943

1952

1946

1942

1945

1942

1955

1943

1950

1942

1945

1945

1943

1955

1946

1942

1947

1942

1950

1949

1942

1946

1944

1954

1954

1943

1940

1942

1954

1946 
Fig 1.1 Benin: protected ecologically sensitive sites

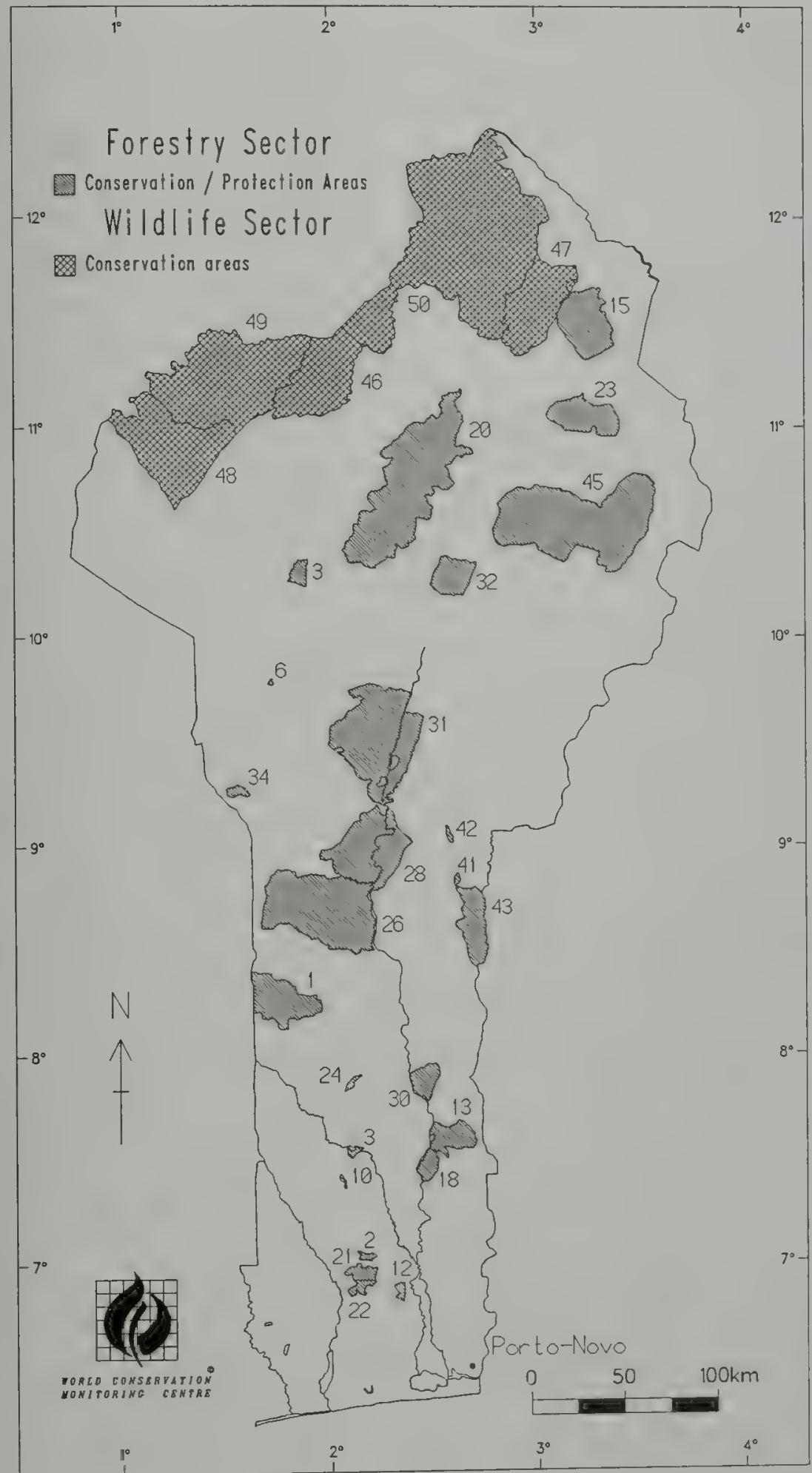


BENIN - PROTECTED SITES (cont.)

National/international designations

Name of area and

map reference (see Fig. 1.1)
Management area (ha)

1,015

1,290

498

84

1,100

2,000

29,030

66

259,500

122,000

188,000

200,000

275,500

568,000

173

345

250

250

203

256

1,090
Year notified

1945

1943

1946

1946

1942

1948

1942

1942

1949

1980

1980

1980

1961

1954

1945

1952

1942

1942

1946

1949

1951

Biosphere Reserves

Réserve de la Biosphere de la Pendjari
880,000

1986 
BENIN - UNPROTECTED SITES

Name of area and

Management

map reference (see Fig. 1.2)

area (ha)

Coastal Swamp Forests

Djessin Biosphere Reserve

10,000

1 Lake Ahéme

2 Lake Nokoué

3 Pobé Forest 
Ecologically Sensitive Sites of Africa

Fig 1.2 Benin: unprotected ecologically sensitive sites

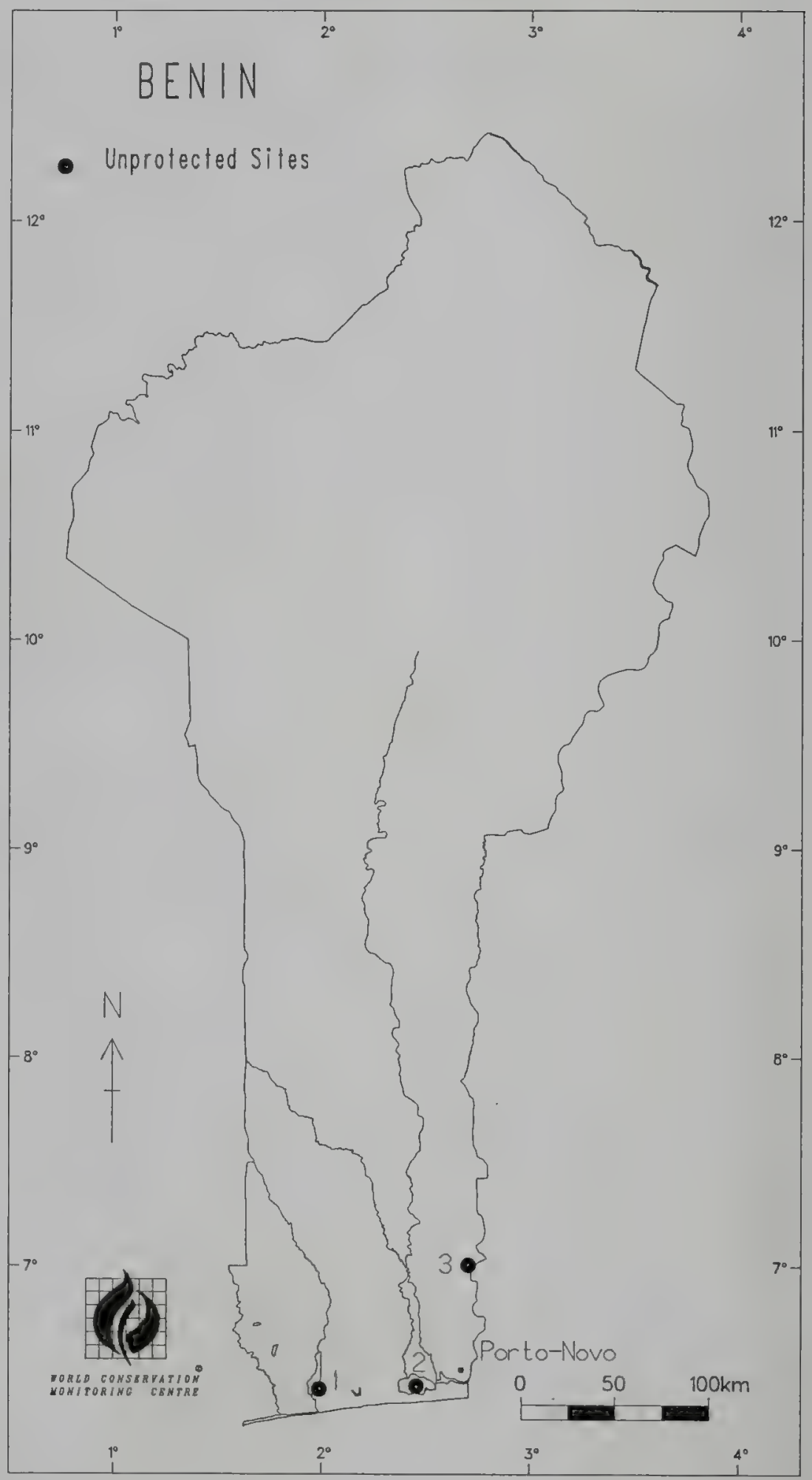




\section{CAMEROON}

\section{INTERNATIONALLY DESIGNATED PROTECTED AREAS}

Bénoué National Park

IUCN Categories II and IX This park of 180,000 ha is a biosphere reserve lying on the Benoue plain at the foot of the Adomaoua plateau, and including Mount Garoua $(1100 \mathrm{~m})$. It is notable for being located at a biogeographical transition area between the Sudanian and Guinean savannas and supports a rich wildlife typical of the area, including threatened species such as elephant, leopard, black rhinoceros, giant eland and Nile crocodile. The major threats are poaching and bushfires; the park is surrounded by a hunting zone. The local people collect firewood and some cultivation takes place (IUCN/UNEP, 1987).

\section{Dja Forest and Faunal Reserve}

IUCN Categories IV, IX and X This biosphere reserve and World Heritage site covers 526,000 ha of fairly flat terrain with a series of rounded hills. The area is notable for being situated at the transition between the forests of south-west Cameroon and those of the Congo Basin, in a region which has not been commercially logged; the dense evergreen rain forest has been little disturbed. The fauna is very diverse and supports a number of threatened species such as lowland gorilla, chimpanzee, elephant and leopard; Bates's weaver, endemic to southern Cameroon, occurs. A number of pygmies live within the reserve, and they are allowed to hunt traditionally. Hunting by modern methods needs controlling, and subsistence farming is encroaching into the area. Investigation of calcareous deposits on the south-east border may lead to open cast mining. The Trans-African highway may be routed near the reserve (IUCN/UNEP, 1987).

\section{Waza National Park}

IUCN Categories II and IX This 170,000ha park and biosphere reserve lies in the Chad Depression, a level area with no perennial rivers. Part of it was once covered by Lake Chad, and there are areas of sand dunes and rock outcrops rising to over $500 \mathrm{~m}$. Vegetation includes a wide range of savanna types, with varying densities of trees. The fauna is rich and varied, including giraffe, elephant, lion, leopard, cheetah, aardvark and ostrich. Lack of water is considered to be a major problem, particularly in recent years of drought. The construction of the Maga Dam ( $25 \mathrm{~km}$ south of the park) and irrigation dykes along the Logone River have prevented periodic flooding and reduced the overall carrying capacity of the park. Poaching is a problem, particularly from Nigeria and Chad, and habitat alteration has occurred through burning and damage by elephant. Some important dry season wildlife watering and grazing areas are outside the park. A few villages exist within the park itself (IUCN/UNEP, 1987). 


\section{NATIONALLY PROTECTED AREAS}

Bouba Ndjidah National Park

IUCN Category II Covering 220,000 ha plus a contiguous hunting zone of 212,600 ha, this park consists mainly of a peneplain with a few rocky outcrops. Savanna and woodland predominate. The park was established to protect populations of black rhinoceros, giant eland and primates. The mammalian fauna is similar to that occurring in Waza National Park, but exists at a lower density; threatened species such as elephant and cheetah occur. There is a buffer zone in which agriculture and hunting are controlled, and poaching, particularly from neighbouring Chad, takes place (IUCN/UNEP, 1987).

Douala-Edea Faunal Reserve

IUCN Category IV Situated on the sandy coastal plain at the mouth of the Sanaga river and bounded inland by an escarpment, this protected area covers an area of $160,000 \mathrm{ha}$. Vegetation consists of coastal evergreen forest, and mangrove forest occurs along the shore. Soils are poor and tree regeneration rates slow, so the reserve is particularly vulnerable to logging. Few trees of commercial value grow here, and disturbance has been limited. The reserve supports at least eight primate species, and the threatened fauna includes black colobus Colobus satanas, mandrill Mandrillus sphinx, chimpanzee, elephant and manatee Trichechus senegalensis. Poaching is a potential problem from the rapidly-expanding settlements nearby (IUCN/UNEP, 1987).

\section{Faro National Park}

IUCN Category II This park covers an area of $330,000 \mathrm{ha}$, and includes a plateau and mountainous massifs. Sudanian savanna and woodland predominate, and gallery forest occurs along river courses. The fauna is rich and diverse ( 33 mammal species), and includes threatened species such as cheetah, black rhinoceros and elephant. There is some poaching, and bush fires are a managerial problem (IUCN/UNEP, 1987).

\section{Kalamaloue National Park}

IUCN Category II This park covers an area of $4500 \mathrm{ha}$ on the border with Chad. It is situated on the floodplain of the Chari River, which retains some water even in very dry years. Vegetation includes open Balanites aegyptiaca savanna, with a more dense savanna in wetter areas. Population densities of a number of animals are relatively high due to the perennial availability of water; elephant and Nile crocodile occur. The small size of the park, coupled with the intensive grazing of domestic animals in surrounding areas and poaching, threatens its integrity. Periodic overgrazing by elephants has also greatly modified the habitat. A road bisects the park, but there are plans to divert it (IUCN/UNEP, 1987).

\section{Kimbi Faunal Reserve}

IUCN Category IV Covering an area of $5625 \mathrm{ha}$, this reserve is notable for being in a transitional area between rain forest and savanna, and supports a large area of gallery forest. A wide variety of mammals occur, including buffalo, baboon and chimpanzee. The reserve is small and elongated, has few staff, and poaching is a problem (IUCN/UNEP, 1987). 
This park of 125,900 ha is contiguous to Ejagham Forest Reserve and Cross River National Park in Nigeria, and is situated on a sandy, flat coastal plain. It is vegetated with medium-altitude Biafran evergreen forest, one of the most florally diverse forest types in Africa; many plants have high levels of defensive chemicals thought to be associated with poor soils. Having never been logged, the forest is relatively undisturbed. The fauna is rich and diverse, with 40 mammal species including 14 primates. Threatened animals include drill, Preuss's red colobus Procolobus [badius] pennanti preussi, black colobus Colobus satanas, Preuss's guenon Cercopithecus preussi, elephant and leopard. The grey-necked picathartes Picathartes oreas occurs. Numbers of park staff are low, and poaching of large mammais occurs from both the Nigerian side and Cameroonian sides; the present hunting level may be too great for populations to be sustained. A buffer zone and rural development schemes are being established in an attempt to relieve pressure on the park (IUCN/UNEP, 1987).

\section{Mbi Crater Faunal Reserve}

IUCN Category IV

The reserve covers $370 \mathrm{ha}$ on the steep sides of an extinct volcanic crater, breached by a stream and containing a crater lake. The crater rim is grass-covered, but some marsh and lowland rain forest occur. The area supports a number of mammal species, including rock hyrax and several primates and ungulates. The reserve is very small, poaching occurs, and there is some grazing of cattle (IUCN/UNEP, 1987).

\section{Mozogo-Gokoro National Park}

IUCN Category I This small park of 1400 ha comprises a shallow basin situated between mountains. Much of the area is still covered with dry woodland savanna dominated by Acacia albida, as the area has been protected from fire for 30 years. A variety of animals, including several primate species, inhabit the area. However, the reserve is very small; indiscriminate burning and the cutting of fuelwood are continuing threats (IUCN/UNEP, 1987).

Santchou Faunal Reserve $7,000 \mathrm{ha}$

IUCN Category IV

\section{OTHER MANAGED SITES}

\section{Bambuko Forest Reserve}

$4^{\circ} 13^{\prime} \mathrm{N}, 9^{\circ} 11^{\prime} \mathrm{E}$ This forest reserve covers $26,677 \mathrm{ha}$ and is the only protected area on Mount Cameroon (Gartlan, 1989; Stuart, 1986).

\section{Bandjoukri Hunting Reserve $58,780 \mathrm{ha}$}

\section{Banyang Mbo Forest Reserve}

$5^{\circ} 20^{\prime}-5^{\circ} 34^{\prime} \mathrm{N}, 9^{\circ} 26^{\prime}-9^{\circ} 45^{\prime} \mathrm{E}$ Covering 38,500 ha east of Ejaghem, the vegetation of this reserve consists chiefly of coastal Biafran forest, rich in species of Caesalpiniaceae. The fauna is similar to that occurring in Korup National Park, and 
includes forest elephant, buffalo and chimpanzee. Atlantic coastal forest endemics such as drill Mandrillus leucophaeus and red-eared guenon Cercopithecus erythotis camerunensis occur (Gartlan, 1989).

Barombi Mbo Forest Reserve

IUCN Category VIII $4^{\circ} 40^{\prime} \mathrm{N}, 9^{\circ} 23^{\prime} \mathrm{E}$ This 885 ha lowland rain forest reserve, situated a few kilometres north-west of Kumba, includes the picturesque crater lake of Lac Barombi, home to 11 endemic cichlid and one endemic catfish species. Chimpanzees and the threatened bare-necked rockfowl Picathartes oreas occur in the forest surrounding the lake. There is agricultural encroachment into the area, but the local people revere the lake. Treatment of the lake to eradicate bilharzia may have had adverse effects (BBC, 1990; Gartlan 1989; IUCN, 1987; Stuart et al., 1990).

\section{Bel Eland Hunting Reserve}

26,000 ha

\section{Bois des Singes Recreation Forest Reserve 25 ha}

Bonepoupa Forest Reserve IUCN Category VIII $4^{\circ} 07^{\prime}-4^{\circ} 20^{\prime} \mathrm{N}, 10^{\circ} 01^{\prime}-10^{\circ} 11^{\prime} \mathrm{E}$ This reserve was established in 1948. Covering 20,000 ha of Atlantic coastal forest north-east of Douala, it is home to the red colobus monkey. The area is hunted (Gartlan, 1989; Stuart et al., 1990).

\section{Boune Dje Hunting Reserve}

97,040ha

\section{Campo Faunal Reserve}

IUCN Category IV This reserve of $300,000 \mathrm{ha}$ includes coastal plain and low hills covered primarily with dense tropical forest. The fauna is varied. . t includes several threatened species such as elephant, gorilla and grey-necked rc. sowl. However, a 27-years old logging concession has resulted in considerable environmental degradation. Heavy poaching of larger mammals occurs, and the human population within the reserve is increasing (IUCN/UNEP, 1987).

\section{Cobas Hunting Reserve}

50,000 ha

\section{Dendeng Forest Reserve}

Improved protection of this forest reserve is required (Stuart et al., 1990).

\section{Densa Hunting Reserve}

70,480 ha

Djibao Hunting Reserve

$64,600 \mathrm{ha}$ 


\section{Dobinga Hunting Reserve}

44,600 ha

\section{Ejagham Forest Reserve}

$5^{\circ} 19^{\prime}-5^{\circ} 50^{\prime} \mathrm{N}, 8^{\circ} 50^{\prime}-9^{\circ} 08^{\prime} \mathrm{E}$ Established in 1934 , this forest reserve covers an area of 74,851 ha immediately to the north of Korup National Park. The topography is primarily low relief in the south, becoming hillier in the north. The forests are principally Guineo-Congolian, characterised by the high number of representatives of the family Caesalpiniaceae. The area is considered to be one of the most important areas for primate conservation in Africa; larger mammals occurring include forest elephant, leopard, chimpanzee, drill, Preuss's colobus, collared mangabey, the rare red-eared guenon, and duiker Cephalophus sylvicultor. It also supports the two very rare toad species, Bufo superciliaris and Nectophryne afra. Dwarf crocodile occur, and the avifauna includes the threatened bare-necked rockfowl (Collar and Stuart, 1988; Gartlan 1989; Stuart et al., 1990).

\section{Elephants Hunting Reserve}

17,000 ha

\section{Faro Coron Hunting Reserve} 56,860 ha

\section{Faro Ouest Hunting Reserve 125,950 ha}

\section{Fungom Forest Reserve}

$6^{\circ} 48^{\prime} \mathrm{N}, 10^{\circ} 05^{\prime} \mathrm{E}$ (centre) Situated near the Nigerian border north of the Bamenda Highlands, this fairly remote area of relatively rugged terrain covers approximately 60,000 ha. Improved protection is required (Stuart et al., 1990).

\section{Grand Capitaine Hunting Reserve} 29,360 ha

\section{Hippopotame Hunting Reserve} $46,950 \mathrm{ha}$

Kalfou Faunal Reserve 1933 4000ha (Stuart et al., 1990).

Kourouk Hunting Reserve 95,000ha

Lac Barombi Forest Reserve - see Barombi Mbo Forest Reserve Lac Balombo Mbo - see Barombi Mbo Forest Reserve 


\section{Lac Ossa Faunal Reserve}

1968 4000ha (Stuart et al., 1990)

\section{Landou Hunting Reserve}

38,370 ha

\section{Logone Birni Hunting Reserve \\ 80,000 ha}

\section{Manehas Forest Reserve}

Situated about $7 \mathrm{~km}$ to the north-east of Mount Kupé, this forest reserve covers almost $600 \mathrm{ha}$ on the lower slopes of the Kupé massif at an altitude of between about $600 \mathrm{~m}$ and $1000 \mathrm{~m}$.

\section{Mayo Duele Hunting Reserve}

64,600 ha

\section{Mayo Louti Forest Reserve}

This 1500 ha forest reserve supports dry forest, and important populations of antelope and other larger mammals (Stuart et al., 1990).

\section{Mayo Oldiri Hunting Reserve}

46,940 ha

\section{Mayo Oldiri Nord Hunting Reserve}

60,000 ha

\section{Mayo Oldiri Sud Hunting Reserve}

38,370 ha

\section{Mayo Sala Hunting Reserve}

38,000 ha

\section{Mbembe Forest Reserve}

$6^{\circ} 52$ 'N, $10^{\circ} 42^{\prime} \mathrm{E}$ Situated on the Nigerian border north of the Bamenda Highlands, this 40,000 ha forest reserve includes gallery forest and some rugged hills reaching over $1000 \mathrm{~m}$ altitude. Improved protection is required (Stuart $e t$ al., 1990).

\section{Metchié Forest Reserve}

$5^{\circ} 02^{\prime} \mathrm{N}, 10^{\circ} 05^{\prime} \mathrm{E}$ This forest reserve is located in the valley of the Metchie river about $20 \mathrm{~km}$ north-west of Bafang, separated by the Metchie River from Santchou Faunal Reserve. It includes both flat valley floor and more rugged terrain (IGN Yaoundé 1:200,000 topographic map). 


\section{Mount Kilum Forest Reserve (Mount Oku)}

$6^{\circ} 12^{\prime} \mathrm{N}, 10^{\circ} 32^{\prime} \mathrm{E}$ Established in 1983 , this forest reserve covers $11,400 \mathrm{ha}$ in the north of the Bamenda Highlands. It includes the areas above Verkovi and Wvem (Ngongba High Forest), the forest above Simonkov and Tadu, and forests to the southwest and north-west of the lake. This is the second highest mountain in West Africa, with deep dissected valleys, grassy plateaus and a shallow caldera lake. Open forest occurs from about $2100 \mathrm{~m}$ to the summit at $3011 \mathrm{~m}$, but burning, and grazing by stock have degraded many areas. It supports 6900 ha of the finest example of Podocarpus and Arundinaria bamboo forest in West Africa. Fauna includes Bannerman's turaco and the banded wattle-eye (endemic to the Bamenda Highlands), the rare Preuss's guenon and several very rare amphibians. It is a vital catchment area, with a high surrounding human population. Uncontrolled fires are a major problem, as are roads, livestock and soil erosion. There is good tourist potential (Collar and Stuart, 1988; Frame 1987; Gartlan, 1989; IUCN, 1987)

\section{Ndock Hunting Reserve}

181,120 ha

\section{Ngoro}

27,000 ha

\section{Nta Ali Forest Reserve}

$5^{\circ} 21^{\prime}-5^{\circ} 38^{\prime} \mathrm{N}, 9^{\circ} 20^{\prime}-9^{\circ} 32^{\prime} \mathrm{E}$ Covering $31,500 \mathrm{ha}$ adjacent to Banyang-Mbo Forest Reserve, this forest is considered to be of biological interest. Its highest point is Mount Nta Ali at $1202 \mathrm{~m}$. Sub-montane, Atlantic coastal and lowland evergreen forests occur, supporting forest elephant, buffalo, blue duiker and Cephalophus dorsalis, bushpig and at least eight primate species, including chimpanzee and Preuss's (red) colobus. The reserve is only $15 \mathrm{~km}$ from Mamfe, and is subjected to hunting (Gartlan, 1989; Stuart et al., 1990,).

\section{Pangar-Djerem}

This $480,000 \mathrm{ha}$ area is contiguous with the eastern side of Mbam et Djerem National Park (proposed). Both areas are similar, but because of human activity Mbam ei Djerem supports less forest. These reserves are unusual in being situated in a transitional zone between forest and savanna. The fauna is one of the richest in Cameroon, and includes threatened species such as chimpanzee, elephant and possibly gorilla. Poaching on a professional basis occurs, particularly in the Pangar-Djerem sector which will now not be proposed as a national park because of this (IUCN/UNEP, 1987).

\section{Rhinoceros Hunting Reserve $72,510 \mathrm{ha}$}

\section{Rivière Mawne Forest Reserve}

$5^{\circ} 45^{\prime}-6^{\circ} 03^{\prime} \mathrm{N}, 9^{\circ} 24^{\prime}-9^{\circ} 32^{\prime} \mathrm{E}$ Established in 1956 , this reserve covers $44,900 \mathrm{ha}$ of principally southern coastal forest at elevations between $500 \mathrm{~m}$ and $1000 \mathrm{~m}$. Seven 
primate species including chimpanzee occur, as well as forest elephant, buffalo, and blue, Cephalophus silvicultur and $C$. dorsalis duiker. The reserve is hunted over, and is the source of many locally-utilised forest products; the surrounding human population is fairly large (Gartlan, 1989).

Rivière Mokoko Forest Reserve

IUCN Category VIII $4^{\circ} 25^{\prime} \mathrm{N}, 9^{\circ} 03^{\prime} \mathrm{E}$ Established in 1952, the reserve covers an area of 9100 ha adjacent to and west of Bambuko Forest Reserve on Mount Cameroon. The forests, principally lowland evergreen rain forests, include gallery and Atlantic coastal forests. Primates that occur include potto, angwantibo, putty-nosed guenon Cercopithecus nictitans, red-eared guenon $C$. erythrotis, collared mangabey Cercocebus torquatus and drill. The area is of biological interest (Gartlan, 1989; Stuart et al., 1990).

\section{Rumpi Hills Forest Reserve}

$4^{\circ} 50^{\prime} \mathrm{N}, 9^{\circ} 06^{\prime} \mathrm{E}$ Situated in south-west Cameroon, north-west of Mount Cameroon and east of Korup National Park, this extensive reserve covers about 44,300ha of relatively low, undulating hills between $1200 \mathrm{~m}$ and $1800 \mathrm{~m}$ in elevation, covered in well-preserved moist forest with montane elements. Three threatened and four nearthreatened bird species occur, including the pigeon Columba albinucha, otherwise only known from Uganda and Zaire. The rare red-eared guenon Cercopithecus erythrotis and Preuss's guenon $C$. preussi, the endemic chameleon Chamaeleo eisentrauti and the very localised toad Werneria tandyi are also found here. The hills are an important water catchment (Collar and Stuart, 1988; Gartlan, 1989; Stuart et al., 1990).

\section{Sadje Hunting Reserve}

26,660 ha

\section{Sanaga Faunal Reserve}

$3^{\circ} 35^{\prime} \mathrm{N}, 9^{\circ} 41^{\prime} \mathrm{E}$ Mangroves worthy of protection occur around the mouth of the Sanaga River (Stuart et al., 1990).

\section{Takamanda Forest Reserve}

$5^{\circ} 59^{\prime}-6^{\circ} 21^{\prime} \mathrm{N}, 9^{\circ} 11^{\prime}-9^{\circ} 30^{\prime} \mathrm{E}$ Established in 1934 , this 67,599 ha forest reserve is situated in the Cross River area between Mamfe and the Nigerian town of Obudu. Primarily vegetated with rain forest and patches of Cameroon Highland montane vegetation, the forests contain many endemic plants, some of which are undescribed, and numerous endemic animals. Larger mammals in the reserve include elephant, leopard and about 12 species of primates, the latter including Preuss's monkey, chimpanzee and an isolated and possibly taxonomically distinct population of northern gorilla. Illegal hunting of gorillas takes place, and uncontrolled fires occur. There is a proposal to create a park on the Nigerian side of the border (Frame 1987; Gartlan, 1989).

\section{Tatou Hunting Reserve}

20,000 ha 


\section{Tcheboa Hunting Reserve}

160,800 ha

Vogzom Hunting Reserve

$85,000 \mathrm{ha}$

Waimba Hunting Reserve

26,200 ha

\section{UNPROTECTED SITES}

\section{Adamaoua Plateau}

This extensive upland area, reaching over $1500 \mathrm{~m}$ in altitude, is an extension of the western Cameroon mountain chain inland from the Bamenda Highlands. It is of biological interest, but habitats are severely fragmented. An isolated population of mountain reedbuck occurs (Stuart et al., 1990).

\section{Bafia Faunal Reserve}

Proposed

42,000 ha

\section{Bakossi Peninsula Mangroves}

$4^{\circ} 32^{\prime} \mathrm{N}, 8^{\circ} 35^{\prime} \mathrm{E}$ This is an extensive area of mangroves at the mouth of the estuary of the Rio del Rey and Akwayafe River, which marks the border with Nigeria. The Bakossi Peninsula covers approximately 40,000 ha within this much larger complex (IUCN 1987).

\section{Bakossi Mountains}

$4^{\circ} 50^{\prime}-5^{\circ} 20^{\prime} \mathrm{N}, 9^{\circ} 30^{\prime}-9^{\circ} 46^{\prime} \mathrm{E}$ Covering about 50,000 ha, these mountains range between $1000 \mathrm{~m}$ and $1819 \mathrm{~m}$. Two forest reserves: Mungo River Forest Reserve and Bakossi Forest Reserve are marked in this area on the IGN 1:200,000 topographic map. The vegetation consists of species-rich submontane forest with several endemics; secondary forest exists around villages. Rare birds such as Malaconotus gladiator and Lioptilus gilberti occur; larger mammals include drill, red-eared nose-spotted monkey, l'Hoest's monkey and chimpanzee (Gartlan, 1989; Stuart et al., 1990).

\section{Bakundu South Forest}

$4^{\circ} 28^{\prime} \mathrm{N}, 9^{\circ} 21^{\prime} \mathrm{E}$ This rain forest is heavily hunted and logged (Frame, 1987).

\section{Bamboutos Forests}

$5^{\circ} 40^{\prime} \mathrm{N}, 10^{\circ} 05^{\prime} \mathrm{E}$ These montane forests occur up to $1500 \mathrm{~m}$ in the Cameroon Highlands $20-80 \mathrm{~km}$ west and south of Bamenda, and include Bamboutos Forest Reserve. They are important in protecting the remaining areas of forest in an area where, due to clearance for agriculture, forests have been largely reduced to those in river valleys. There is a very high level of bird and vascular plant endemism, and the surrounding areas are densely populated, resulting in pressures to clear the remaining forests (Frame, 1987; Stuart, 1986). 


\section{Bamileke Plateau}

Areas around Foto, Bangwa and Petit Diboum, although fragmented, are important for amphibian conservation (Stuart et al., 1990).

Boumbabek Faunal Reserve

Proposed $2^{\circ} 08^{\prime}-2^{\circ} 58^{\prime} \mathrm{N}, 14^{\circ} 43^{\prime}-15^{\circ} 16^{\prime} \mathrm{E}$ This important forest in the remote south-east covers about 233,000 ha at elevations between $300 \mathrm{~m}$ and $700 \mathrm{~m}$. Consisting primarily of mixed evergreen and semi-deciduous transitional forests, it supports a full complement of forest fauna including elephant, buffalo, bongo, bushbuck, giant forest hog, bushpig and leopard, as well as gorilla, collared mangabey and chimpanzee (Gartlan, 1989; Stuart et al., 1990).

Lac Lobeke Faunal Reserve

Proposed $2^{\circ} 15^{\prime} \mathrm{N}, 15^{\circ} 40^{\prime} \mathrm{E}$ Established in 1974 , this important 43,000 ha forest is in the remote south-east of the country. The creation of a larger protected area of 92,000 ha has been recommended, which would link it with the Dzanga-Ndoki National Park in the Central African Republic. Primarily supporting a mixed transitional evergreen and semi-deciduous forest, it is home to a wide variety of forest fauna including elephant, buffalo, sitatunga, six duiker species, chevrotain, giant forest hog, bushpig, leopard, antbear, giant pangolin, nine diurnal primate species and particularly high densities of bongo and pygmy antelope (Gartlan, 1989; Stuart et al., 1990).

\section{Mandara Mountains}

Situated in the extreme north of the country, these mountains are known to support rare plant species. Mountain reedbuck possibly occur (Stuart et al., 1990).

\section{Manne River}

This area should be accorded protected status (Stuart et al., 1990).

Mbam et Djerem Faunal Reserve

Proposed

This reserve covers $353,180 \mathrm{ha}$, and has been proposed as a national park. It is contiguous with the western side of Pangar-Djerem Hunting Reserve; both areas are similar, but Mbam et Djerem supports less forest due to human activity, although it is less heavily hunted than the latter reserve. These reserves are situated in a transitional zone between forest and savanna. The fauna is one of the richest in Cameroon, and includes threatened species such as chimpanzee, elephant and possibly gorilla. Professional poaching occurs, particularly to the east of the Pangar river (IUCN/UNEP, 1987).

\section{Mount Cameroon}

$4^{\circ} 01^{\prime}-4^{\circ} 25^{\prime} \mathrm{N}, 8^{\circ} 59^{\prime}-9^{\circ} 22^{\prime} \mathrm{E}$ Situated near the coast $45 \mathrm{~km}$ west of Douala, this is the highest mountain and only active volcano in West Africa. It is particularly important as one of the few sites in tropical Africa supporting a full continuum between lowland and montane forest. Forest occurs at elevations from close to sea-level to about $2000 \mathrm{~m}$, covering about $175,000 \mathrm{ha}$. Montane grassland occurs at higher elevations. The mountain is a major centre of endemism, and an important locality for Preuss's 
guenon, red-eared nose-spotted monkeys, chimpanzees, drill and elephant. The endemic Mount Cameroon francolin, three species of threatened and four nearthreatened bird species occur. The skink Panaspis gemmiventris, the toads Didynamipus sjoestedti and Werneria preussi, and the very rare tree-frog Hyperolius krebsi occur. Fire is thought to be partly responsible for maintaining the forestgrassland boundary, and illegal cutting of timber and hunting occur. Only Bambuko Forest Reserve on the north-west side is in any way protected. A proposal has been made to protect Mount Etinde (Little Mount Cameroon), where montane rain forest occurs at an unusually low elevation (Collar and Stuart, 1988; Frame 1987; Gartlan, 1989; Stuart, 1986).

\section{Mount Kupé}

$4^{\circ} 48^{\prime} \mathrm{N}, 9^{\circ} 42^{\prime} \mathrm{E}$ Situated in south-west Cameroon, this is the first major peak $(2,064 \mathrm{~m})$ inland from Mount Cameroon. A small area is marked as a forest reserve on the official maps of the region. Its flanks are forested from elevations between $900 \mathrm{~m}$ to the summit at $2064 \mathrm{~m}$, covering an area of $2000 \mathrm{ha}$ and including transitional lowland-montane forest, with montane forest near the peak. Tree species include Carapa grandiflora, Cephaelis mannii, Dicranolepis vestita and Ficus mucuso, with Podocarpus latifolius and Philippia mannii on the summit. It is the principal (and perhaps the only) locality for at least 15 species of plant. Over 190 bird species occur, including the endemic Mount Kupé bush shrike; three threatened and three nearthreatened bird species also occur. The mountain also supports an endemic skink. Primates include the rare red-eared guenon Cercopithecus erythrotis and drill. Threats to the area include clearance for agriculture and cutting of trees, as the surrounding area is densely populated; a local taboo which, until now, helped preserve the forest, is diminishing in importance (Collar and Stuart, 1988; Frame, 1987; Gartlan, 1989; IUCN, 1987; Stuart, 1986).

\section{Mount Manenguba}

$5^{\circ} 01^{\prime} \mathrm{N}, 9^{\circ} 50^{\prime} \mathrm{E}$ Situated in the western Cameroon mountain chain north-east of Mount Kupé, this is an extinct volcano reaching $2411 \mathrm{~m}$, with two crater lakes. Less than 1000 ha of dry, stunted montane forest remain and grassland now covers most of the mountain, with little forest remaining on the lower slopes. One vulnerable and one near-threatened bird species occur, including Bannerman's weaver Ploceus bannermani, as do two localised species of rodents, an endemic chameleon, five endemic frogs and two very localised toads. Human pressures in the area are severe; firewood collection occurs and habitat fragmentation is taking place (Collar and Stuart, 1988; Frame, 1987; Stuart, 1986; Stuart et al., 1990).

\section{Mount Nlonako}

$4^{\circ} 53^{\prime} \mathrm{N}, 9^{\circ} 55^{\prime} \mathrm{E}$ Lying to the south-east of Mount Manenguba, about $2000 \mathrm{ha}$ of this $1825 \mathrm{~m}$ granite mountain is covered in closed canopy forest transitional between montane and lowland forests. An area of $3500 \mathrm{ha}$ is recommended for protection. Three threatened and two near-threatened bird species occur. There has been some deforestation, particularly on the lower slopes, but the rugged terrain affords a measure of protection (Collar and Stuart, 1988; Frame, 1987; Stuart, 1986). 


\section{Nanga-Eboke Faunal Reserve}

16,000 ha

\section{Ngoro Faunal Reserve \\ 27,000 ha}

Nki Faunal Reserve

Proposed $2^{\circ} 07^{\prime}-2^{\circ} 30^{\prime} \mathrm{N}, 14^{\circ} 09^{\prime}-14^{\circ} 48^{\prime} \mathrm{E}$ This is an important area in the remote south-east, covering about $195,000 \mathrm{ha}$ of evergreen and transitional rain forest; it includes the spectacular Nki waterfall. Elephant, buffalo, bongo, collared mangabey, gorilla, chimpanzee and leopard occur, as do long-snouted crocodile and the giant frog Conrauana goliath. The area has been little disturbed (Gartlan, 1989; Stuart et al., 1990).

\section{Nyong River Swamp Forests}

$4^{\circ} 00^{\prime} \mathrm{N}, 13^{\circ} 10^{\prime} \mathrm{E}$ Situated in the Guineo-Congolian biome near Abong Mbang, these constitute an unique and currently unprotected vegetation type (Frame, 1987; Stuart et al., 1990).

\section{Rio Del Rey}

$4^{\circ} 20^{\prime}-4^{\circ} 56^{\prime} \mathrm{N}, 8^{\circ} 32^{\prime}-9^{\circ} 02^{\prime} \mathrm{E}$ Incorporating 180,000 ha of mangroves and $4000 \mathrm{ha}$ of mudflats, this large estuary is of importance to waders and waterfowl, including avocets. It is a major mangrove area, with interesting fish faunas in the brackish and freshwater swamps. See also Bakossi Peninsula Mangroves (Altenburg 1987; Stuart et al., 1990).

\section{Tchabal Mbabo}

$7^{\circ} 16^{\prime} \mathrm{N}, 12^{\circ} 10^{\prime} \mathrm{E}$ Situated to the north-east of Bamenda below an elevation of $2460 \mathrm{~m}$, near Gashaka-Gumti National Park in Nigeria, this is the most northerly outlier of the western Cameroon montane forests. About 30,000 ha of forest occur up to $1500 \mathrm{~m}$. Currently unprotected and relatively isolated, it is home to several rare montane bird species. The mammalian fauna is unstudied. The forests are degraded, fragmented and disturbed, and fires are frequent (Frame, 1987; Gartlan, 1989; Stuart et al., 1990). 


\section{CAMEROON - PROTECTED SITES}

National/international designations

Name of area and

map reference (see Fig. 2.1)

Management

area (ha)

300,000

526,000

160,000

5,625

4,000

370

16,000

7,000

58,780

26,000

97,040

50,000

70,480

64,600

44,600

17,000

56,860

125,950

29,360

46,950

95,000

38,370

80,000

64,600

46,940

60,000

38,370

38,000

181,120

72,510

26,660

20,000

160,800

85,000

26,200

30 Ndock

31 Rhinoceros

32 Sadje

33 Tatou

34 Tcheboa

35 Vogzom

36 Waimba

1932

1950

1932

1964

1968

1964

1933
Year

notified

1933


Ecologically Sensitive Sites of Africa

Fig 2.1 Cameroon: protected ecologically sensitive sites

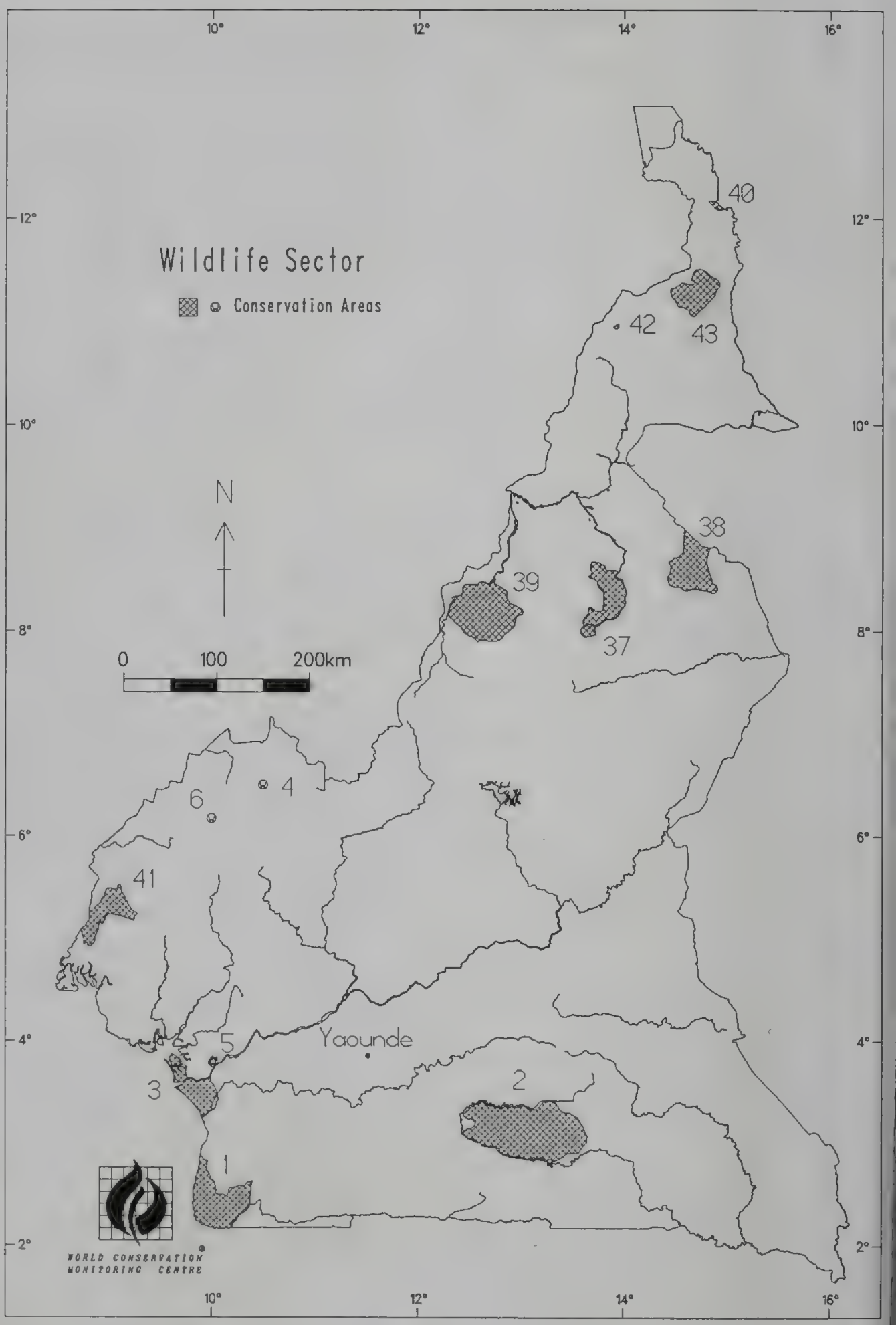


CAMEROON - PROTECTED SITES (cont.)

National/international designations

Name of area and

map reference (see Fig. 2.1)

Management

area (ha)

National Parks

37 Benoue

38 Bouba Ndjidah

39 Faro

40 Kalamaloue

41 Korup

42 Mozogo-Gokoro

43 Waza

Protection Forests

44 Bakwery

45 Barombi-Mbolake

46 Mbamidjin

47 Mont Koupe

48 Mont-Bamboutos

49 Monts Ekasekas

50 Mouma

51 Nkilzock

52 Obala

Recreation Forest

53 Bois des Singes

\section{Biosphere Reserves}

Parc national de Waza

Parc national de la Benoue

Réserve forestière et de faune du Dja

\section{World Heritage Sites}

Dja Faunal Reserve
180,000
220,000

330,000

4,500

125,900

1,400

170,000

9,324

885

145

300

222

250

10,000

3,000

23,550

25
Year

notified

1968

1968

1980

1972

1986

1968

1968

1948

1936

1936
170,000

180,000

500,000

1979

1981

1981

526,000 


\section{CAMEROON - UNPROTECTED SITES}

Name of area and

map reference (see Fig. 2.2)
Management

area (ha)

42,000

43,000

353,180

7 Mbam et Djerem Faunal Reserve

8 Mount Cameroon

9 Mount Kupé

10 Mount Manenguba

11 Mount Nlonako

Nanga-Eboke Faunal Reserve

Ngoro Faunal Reserve

12 Nki Faunal Reserve

13 Nyong River Swamp Forests

14 Rio Del Rey

15 Tchabal Mbabo 
Fig 2.2 Cameroon: unprotected ecologically sensitive sites

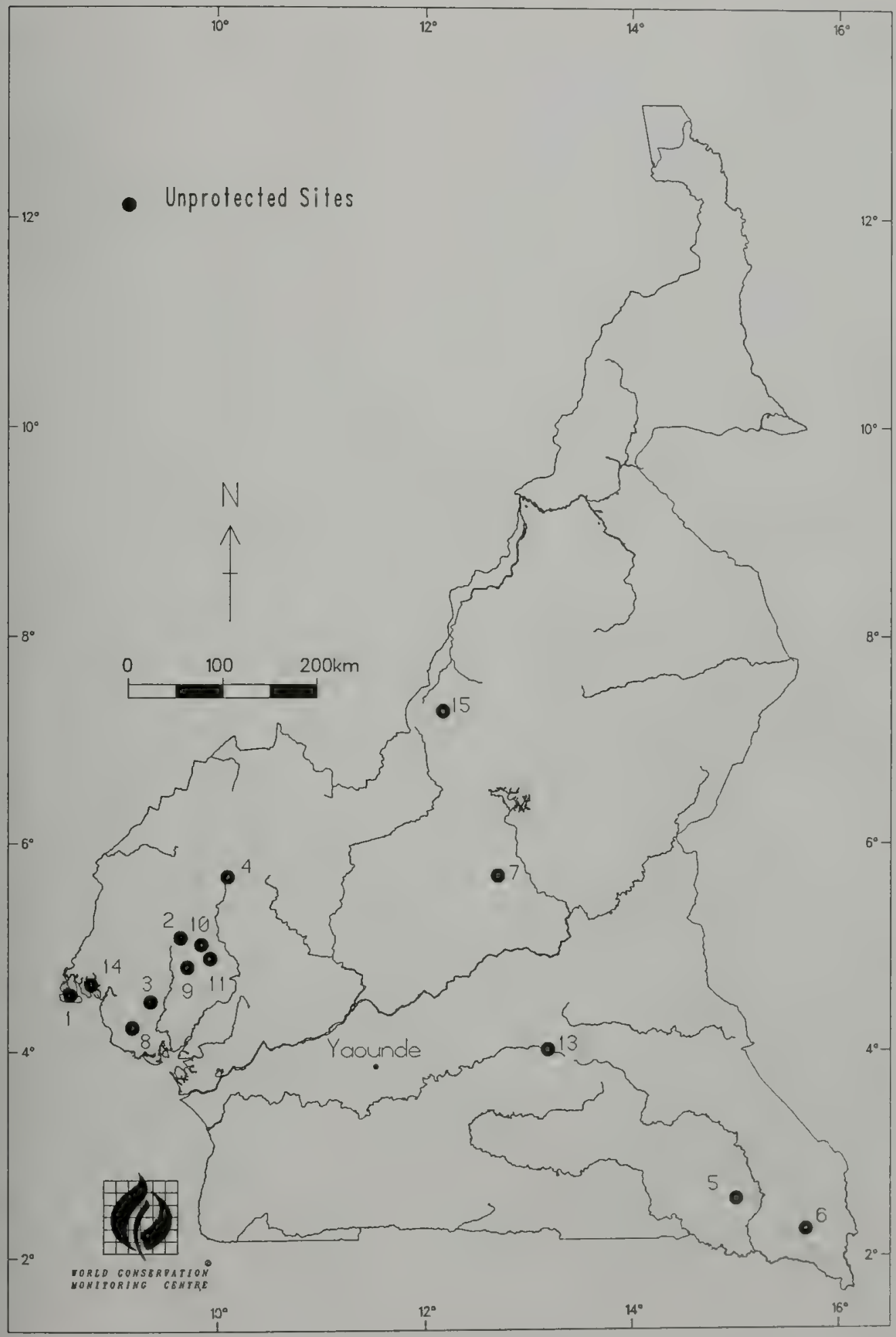





\section{CENTRAL AFRICAN REPUBLIC}

\section{INTERNATIONALLY DESIGNATED PROTECTED AREAS}

Bamingui-Bangoran Conservation Area

IUCN Categories II, IV and IX This biosphere reserve complex of $1,622,000$ ha comprises Bamingui-Bangoran National Park $(1,070,000 \mathrm{ha})$, which surrounds Vassako-Bolo Strict Nature Reserve ( $86,000 \mathrm{ha})$. A number of reserves form a buffer zone: Koukourou-Bamingui Faunal Reserve (110,000ha), Gribingui-Bamingui Faunal Reserve $(438,000 \mathrm{ha})$ and part of Avakaba Presidential Park. The complex is situated in a low-lying area traversed by three seasonal rivers; Sudano-Guinean savanna predominates. The fauna was very rich in the past, and still includes a wide range of migratory species and threatened animals. Black rhinoceros may have disappeared, however, and elephant numbers have been severely reduced (Bosquet, 1986) since poaching continues uncontrolled in the faunal reserves. Insecticides are extensively used on cotton crops outside the reserve, and have killed many fish in the Bamingui River. Various types of cultivation occur within parts of the peripheral reserves (IUCN/UNEP, 1987; MacKinnon and MacKinnon, 1986).

Bamingui-Bangoran National Park

IUCN Categories II and IX This is a 1,070,000ha national park which is part of the Bamingui-Bangoran Conservation Area (see that entry).

\section{Basse-Lobaye Forest}

IUCN Category IX

This biosphere reserve covers 18,200 ha on the Congo border. It includes dense humid semi-deciduous forest, with secondary forest on abandoned farmland in some northern parts. Various species of duiker and monkey are common, but threatened species such as chimpanzee Pan troglodytes, leopard and forest elephant Loxodonta africana cyclotis are rare. The area is inhabited by hunter-gatherer pygmies, but there are other villages, around which there is considerable disturbance, on the northern edge of the forest (IUCN/UNEP, 1987; MacKinnon and MacKinnon, 1986).

Manovo-Gounda-Saint Floris National Park

IUCN Categories II and X The park covers an area of $1,740,000 \mathrm{ha}$ and is contiguous to Aouk-Aoukale Faunal Reserve (330,000ha) and Ouandjia-Vakaga Faunal Reserve $(130,000 \mathrm{ha})$. It comprises open plains, parts of which are seasonally flooded, and areas of more undulating relief. Sudano-Guinean savanna woodland is the predominant vegetation type, but a remarkable diversity of habitats are present. The park is transitional between several biotopes, and supports the richest fauna in the country. A number of threatened species occur, including black rhinoceros, elephant, leopard, cheetah, African wild dog, Nile crocodile and shoebill stork Balaeniceps rex. Some 320 species of birds have been identified. Poaching, particularly by professionals from Chad and Sudan, has had a significant effect on numbers of rhinoceros and elephant, and has greatly reduced giraffe and crocodile populations in the past. Cattle, mainly from Chad and Sudan, invade the area in the dry season, a situation aggravated by drought and overgrazing outside the park. Staff and equipment are inadequate to prevent these 
violations, or the illegal burning which is changing vegetation composition (IUCN/UNEP, 1987).

\section{NATIONALLY PROTECTED AREAS}

André Felix National Park

IUCN Category II

This park covers 170,000 ha of extensive plains with lateritic soils, covered with wooded savanna. It is completely surrounded by Yata-Ngaya Faunal Reserve, which forms the buffer zone. The fauna has been seriously depleted, with few surviving large wildlife species. The buffalo population was decimated by disease in the 1960 s. There are no surveillance patrols, and poaching and cattle grazing proceed unchecked (IUCN/UNEP, 1987).

\section{Aouk-Aoukale Faunal Reserve}

IUCN Category IV The reserve covers an area of 330,000 ha contiguous to Manovo-Gounda-Saint Floris National Park, and comprises flood plains with wooded Sudanian savanna. The fauna is representative of this vegetation type and includes elephant, lion, giraffe and buffalo, as well as some Sahelian species. Ostrich are also present. However, some poaching occurs and the area is grazed by the livestock of nomadic peoples (IUCN/UNEP, 1987).

Gribingui-Bamingui Faunal Reserve

IUCN Category IV This is a 438,000 ha reserve, which is part of Bamingui-Bangoran Conservation Area (see that entry).

Koukourou-Bamingui Faunal Reserve

IUCN Category IV This is a 110,000 ha reserve, which is part of Bamingui-Bangoran Conservation Area (see that entry).

Nana-Barya Faunal Reserve

IUCN Category IV Covering an area of $230,000 \mathrm{ha}$, this reserve is situated on a flat, wooded plain of Isoberlinia savanna. There was originally a rich Sudano-Guinean fauna with elephant, lion, buffalo, black rhinoceros, giraffe and several ungulate species, but due to heavy poaching and a lack of surveillance or protection, the area is now almost devoid of large wildlife (IUCN, 1990b; IUCN/UNEP, 1987).

Ouandjia-Vakaga Faunal Reserve

IUCN Category IV This reserve of 130,000 ha is contiguous to Manovo-Gounda-Saint Floris National Park $(1,740,000 \mathrm{ha})$, and is situated on a sandy plateau covered with Isoberlinia wooded savanna. Wildlife is sparse, but is similar to that found in the national park; threatened species such as elephant, black rhinoceros, cheetah, shoebill stork and several antelope species occur. There are fishing villages along the river that runs through the reserve, and hunting is permitted over a large part of the area. Illegal hunters and shepherds, more particularly from Chad and Sudan, use the area and poaching is a problem (IUCN/UNEP, 1987). 
Vassako-Bolo Strict Nature Reserve

IUCN Categories I

This is an 86,000 ha nature reserve which is part of Bamingui-Bangoran Conservation Area (see that entry), and entirely enclosed by Bamingui-Bangoran National Park (IUCN/UNEP, 1987).

Yata-Ngaya Faunal Reserve

IUCN Category IV

This reserve of 420,000ha completely surrounds the Andre Felix National Park $(170,000 \mathrm{ha})$. It is situated on a sandy plain with hills in the central region, and is predominantly covered with Isoberlinia wooded savanna. Some hills are important for endemic plant conservation. The fauna is little known, though black and white rhinoceros possibly occur; another threatened species which inhabits the area is the giant eland Tragelaphus derbianus. However, no infrastructure or controls have been set up, the reserve is used by nomads, and poaching occurs in the area. About $203,000 \mathrm{ha}$ are leased to a hunting organisation, a condition of use being adherence to regulations in force for the rest of the reserve (IUCN, 1990b; IUCN/UNEP, 1987).

Zemongo Faunal Reserve

IUCN Category IV This $1,010,000$ ha reserve consists of plains which are usually without surface water during the dry season. The lateritic sands of the area support dense Isoberlinia wooded savanna. The fauna is not well known but includes threatened species such as giant eland, black rhinoceros and possibly elephant. Hunting is allowed in about 60,000 ha of the reserve, but difficulty of access prevents control of the interior, and poaching occurs. Little wildlife remains as a result (IUCN, 1990b; IUCN/UNEP, 1987).

\section{OTHER MANAGED AREAS}

\section{Avakaba Presidential Park}

IUCN Category VIII This private hunting area of 250,000 ha is under the control of the president, and visits are at his invitation. Part of the area is within the 1,070,000ha Bamingui-Bangoran Biosphere Reserve. The reserve is situated on a floodplain and includes the permanent 50 ha Lake Avakaba. Wooded savanna covers much of the area. There is some hunting within the reserve (IUCN/UNEP, 1987).

Badada Kere Classified Forest

IUCN Category VIII

Established in 1952; 200 ha

Bako Malikpa Classified Forest

IUCN Category VIII

Established in 1952; $200 \mathrm{ha}$

Bandengue Classified Forest

IUCN Category VIII

195ha 
90ha 
Pami Classified Forest

IUCN Category VIII

Established in 1951; 5000ha

Pamia Classified Forest

IUCN Category VIII

Established in 1952; 9000 ha

Pande Zamaga Classified Forest

Established in 1953; 40,000ha

IUCN Category VIII

Paoua Classified Forest

20ha

IUCN Category VIII

Paya Classified Forest

Established in 1956; 31 ha

IUCN Category VIII

Pepoulou Classified Forest

Established in 1950; 1500ha

IUCN Category VIII

Poto Poto Classified Forest

IUCN Category VIII

Established in $1951 ; 3500$ ha

Pradama Classified Forest

20ha

Sabo Classified Forest

Established in 1953; 26,000ha

Seriki Classified Forest

IUCN Category VIII

Established in 1952; 5700ha

Tomi Classified Forest

Established in $1952 ; 1800$ ha

Yakamele Classified Forest

Established in 1951; 3000ha

Yangana Classified Forest

Established in 1952; 6050ha

Zizi Classified Forest

Established in 1951; 10,000ha

IUCN Category VIII

IUCN Category VIII

IUCN Category VIII

IUCN Category VIII

IUCN Category VIII

IUCN Category VIII 


\section{UNPROTECTED SITES}

Bahr Oulou Faunal Reserve

Proposed

An area of 320,000 ha is proposed for protection, contiguous to Aouk-Aoukale Faunal Reserve, Ouandjia-Vakaga Faunal Reserve and Manovo-Gounda-Saint Floris National Park.

\section{Bamingui-Bangoran Hunting Concession}

$7^{\circ} 35^{\prime} \mathrm{N}, 20^{\circ} 33^{\prime} \mathrm{E}$ (centre) Situated east of and adjacent to Bamingui-Bangoran National Park and Koukourou-Bamingui Faunal Reserve, this area has been suggested for protection (Stuart et al., 1990).

\section{Bongo Sanctuary}

Proposed

An area of 265,000 ha has been proposed as a protected area. This includes the southwest tip of the country, projecting between Cameroon and the Congo.

\section{Dzanga-Sangha Dense Forest Reserve}

$2^{\circ} 14^{\prime}-3^{\circ} 16^{\prime} \mathrm{N}, 15^{\circ} 45^{\prime}-16^{\circ} 33^{\prime} \mathrm{E}$ (approx.) Covering $335,900 \mathrm{ha}$, this forest reserve lies in the extreme south-west of CAR between Cameroon and the Congo, including the 122,000 ha of Dzanga-Ndoki National Park. The southern alluvial zone is flat, but rises to the north-west where slopes can be steep, ranging between $350 \mathrm{~m}$ and $692 \mathrm{~m}$. Vegetation types include dense evergreen and deciducus Central African rain forests, and a transition zone. Fauna includes significant populations of lowland gorilla, chimpanzee, forest elephant, bongo, buffalo and other species. The area is inhabited by the Ba Binga Aka pygmies at a density of about 1 person $/ 2 \mathrm{~km}^{2}$. In addition to commercial logging, there is subsistence hunting and cultivation, gathering of forest products and limited coffee growing. There is tourist potential (Frame, 1987; IUCN, 1987).

\section{Kaga-Bandoro Forests}

$6^{\circ} 53^{\prime} \mathrm{N}, 19^{\circ} 15^{\prime} \mathrm{E}$ Situated just to the east of Kaga-Bandoro town, these lowland forests require protection (Stuart et al., 1990).

\section{Kotto Forests}

$4^{\circ} 28^{\prime} \mathrm{N}, 22^{\circ} 06^{\prime} \mathrm{E}$ This is a suitable area for protection of lowland forest south of Kembé, bounded on the south by the Oubangui River (Stuart et al., 1990).

\section{Massif de Bangassou}

$4^{\circ} 47^{\prime} \mathrm{N}, 22^{\circ} 51^{\prime} \mathrm{E}$ Lowland forests around the town of Bangassou require protection, especially on Mont Bangassou where a duiker survey is needed (Stuart et al., 1990).

\section{Massif des Bongo}

$8^{\circ} 20^{\prime} \mathrm{N}, 21^{\circ} 55^{\prime} \mathrm{E}$ This mountain range in the north-east of the country has been identified as being important for plant conservation, as endemics occur. An area of 265,000ha has been recommended for protection (IUCN, 1987; Stuart et al., 1990). 


\section{Mbaéré-Bodingué-Ngoto}

$3^{\circ} 45^{\prime} \mathrm{N}, 17^{\circ} 16^{\prime} \mathrm{E}$ Situated near Basse-Lobaye Forest and south of Forêt de Ngoto Reserve between the Bodingué and Mbaéré rivers, this is a suitable site for the sustainable use of forest resources (Stuart et al., 1990).

\section{Nana Forests}

This is a suitable area for protection of lowland forests, of high biological interest (Stuart et al., 1990).

\section{Ouadda Forest}

$8^{\circ} 04^{\prime} \mathrm{N}, 22^{\circ} 24^{\prime} \mathrm{E}$ (Ouadda town) This is a large area of dry forest to the south of Ouadda town (Stuart et al., 1990).

\section{Safeca Hunting Concession}

$9^{\circ} 05^{\prime} \mathrm{N}, 22^{\circ} 50^{\prime} \mathrm{E}$ (approx.) This concession is situated between André Felix National Park and Ouandjia-Vakaga Faunal Reserve (Stuart et al., 1990).

\section{Sangba River Area}

$7^{\circ} 44^{\prime} \mathrm{N}, 21^{\circ} 00^{\prime} \mathrm{E}$ This enclave in the east of Bamingui-Bangoran Hunting Concession is worthy of protection. The "Secteur Rhinoceros", covers 270,000ha (Stuart et al., 1990). 435,900ha 
CENTRAL AFRICAN REPUBLIC - PROTECTED SITES

National/international designations

Name of area and

map reference (see Fig. 3.1)

$\begin{array}{ll}\text { Management } & \text { Year } \\ \text { area (ha) } & \text { notified }\end{array}$

Classified Forests

1 Badada Kere

2 Bako Malikpa

3 Bandengue

4 Banzoum

5 Batangafo

6 Batouri Kadei

7 Batouri Sadowa

8 Bengue

9 Birini

10 Bolee

11 Botambi

12 Boungou

13 Calvaire

14 Collines de Bangui

15 Côte des Singes

16 Disso Donago

17 Herman

18 Landjia

19 Lole

20 Lotomo

21 Loumi

22 Mobaye

23 Mokinda

24 N'dres

25 Nan Barya Ngoudou

26 Nayomo Guimi

27 Ngotto

28 Ngoulo

29 Nidou

30 Ohou

31 Ouabere

32 Ouele Ouele

33 Pami

34 Pamia

35 Pande Zamaga

36 Paoua

37 Paya

38 Pepoulou

39 Poto Poto
200

200

195

5,600

17,900

110,000

23,500

80

120,000

90

11,700

16,000

112

195

6,500

7,500

36

270

1,900

5,500

6,000

2,180

415

30

400

150

62,500

150

18

120,000

330

2,200

5,000

9,000

40,000

20

31

1,500

3,500
1952

1952

1950

1955

1953

1952

1954

1951

1950

1952

1952

1952

1952

1952

1956

1948

1951

1951

1950

1951

1948

1951

1950

1951

1950

1952

1951

1952

1953

1956

1950

1951 
Ecologically Sensitive Sites of Africa

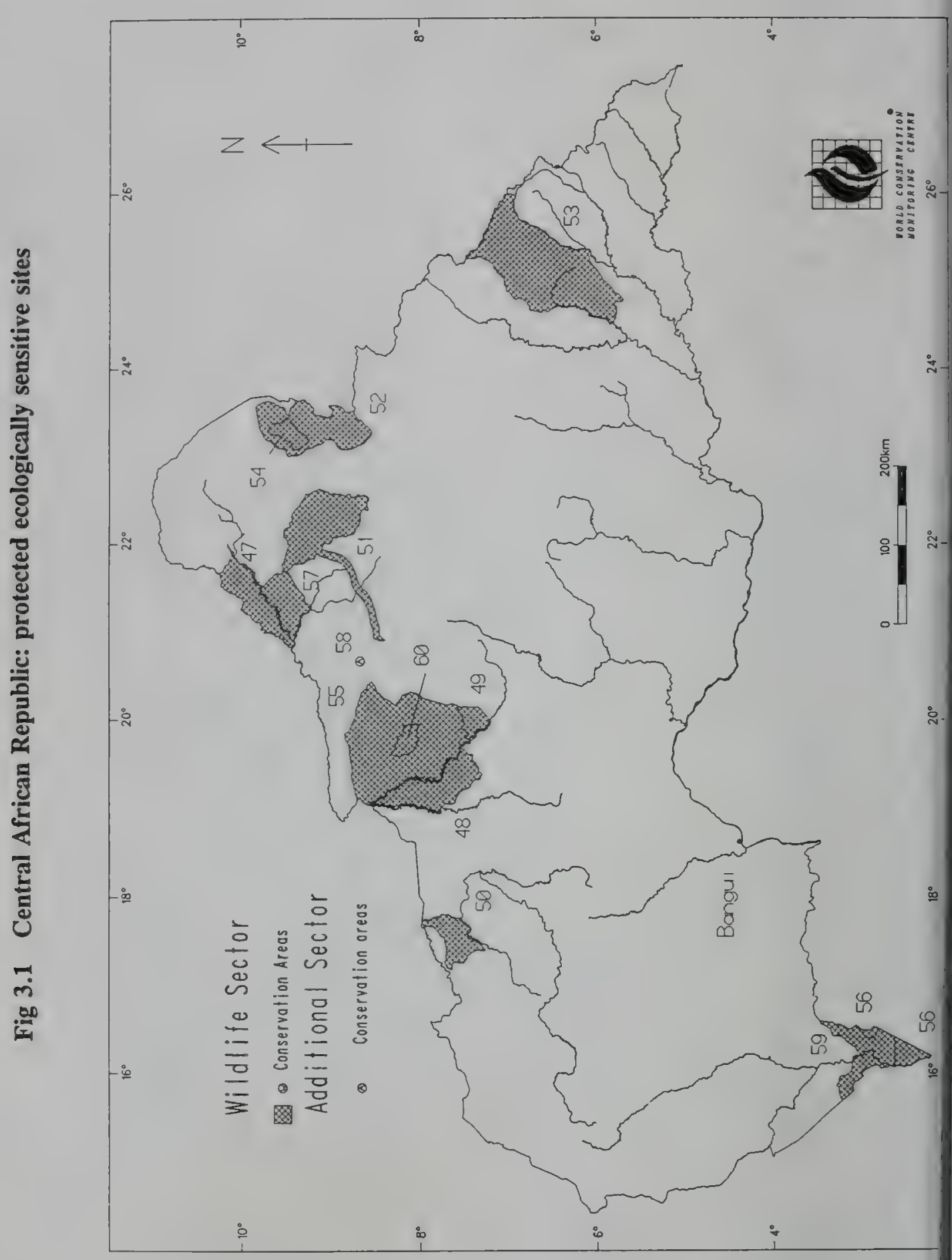




\section{CENTRAL AFRICAN REPUBLIC - PROTECTED SITES (cont.)}

National/international designations

Name of area and

map reference (see Fig. 3.1)

$\begin{array}{ll}\begin{array}{c}\text { Management } \\ \text { area (ha) }\end{array} & \begin{array}{l}\text { Year } \\ \text { notified }\end{array}\end{array}$

40 Pradama

41 Sabo

42 Seriki

43 Tomi

44 Yakamele

45 Yangana

46 Zizi

\section{Faunal Reserves}

47 Aouk-Aoukale

48 Gribingui-Bamingui

49 Koukourou-Bamingui

50 Nana-Barya

51 Ouandjia-Vakaga

52 Yata-Ngaya

53 Zemongo

\section{National Parks}

54 André Felix

55 Bamingui-Bangoran

56 Dzanga-Ndoki

57 Manovo-Gounda-Saint Floris

Private Reserve

58 Avakaba Presidential Park

250,000

1953

1952

1952

1,800

1951

6,050

1952

10,000

1951

330,000

1939

438,000

1940

110,000

1940

230,000

1960

130,000

1925

420,000

1960

$1,010,000$

1925

170,000

1960

$1,070,000$

1933

122,000

1990

$1,740,000$

1933

Special Reserve

59 Dzanga-Sangha

335,900

1990

Strict Nature Reserve

60 Vassako-Bolo

86,000

1960

Biosphere Reserves

Bamingui-Bangoran

Conservation Area

Basse-Lobaye Forest

$1,622,000$

1979

18,200

1977

\section{World Heritage Sites}

Parc National de

Manovo-Gounda-St Floris

$1,740,000$ 
Ecologically Sensitive Sites of Africa

\section{CENTRAL AFRICAN REPUBLIC - UNPROTECTED SITES}

Name of area and

map reference (see Fig. 3.2)
Management area (ha)

320,000

265,000

1 Bamingui-Bangoran Hunting Concession Bongo Sanctuary

2 Dzanga-Sangha-Dense Forest Reserve

3 Kaga-Bandoro Forests

4 Kotto Forests

5 Massif de Bangassou

6 Massif des Bongo

7 Mbaéré-Bodingué-Ngoto

Nana Forests

8 Ouadda Forest

9 Safeca Hunting Concession

10 Sangba River Area

Sangha Economique National Park

435,900 


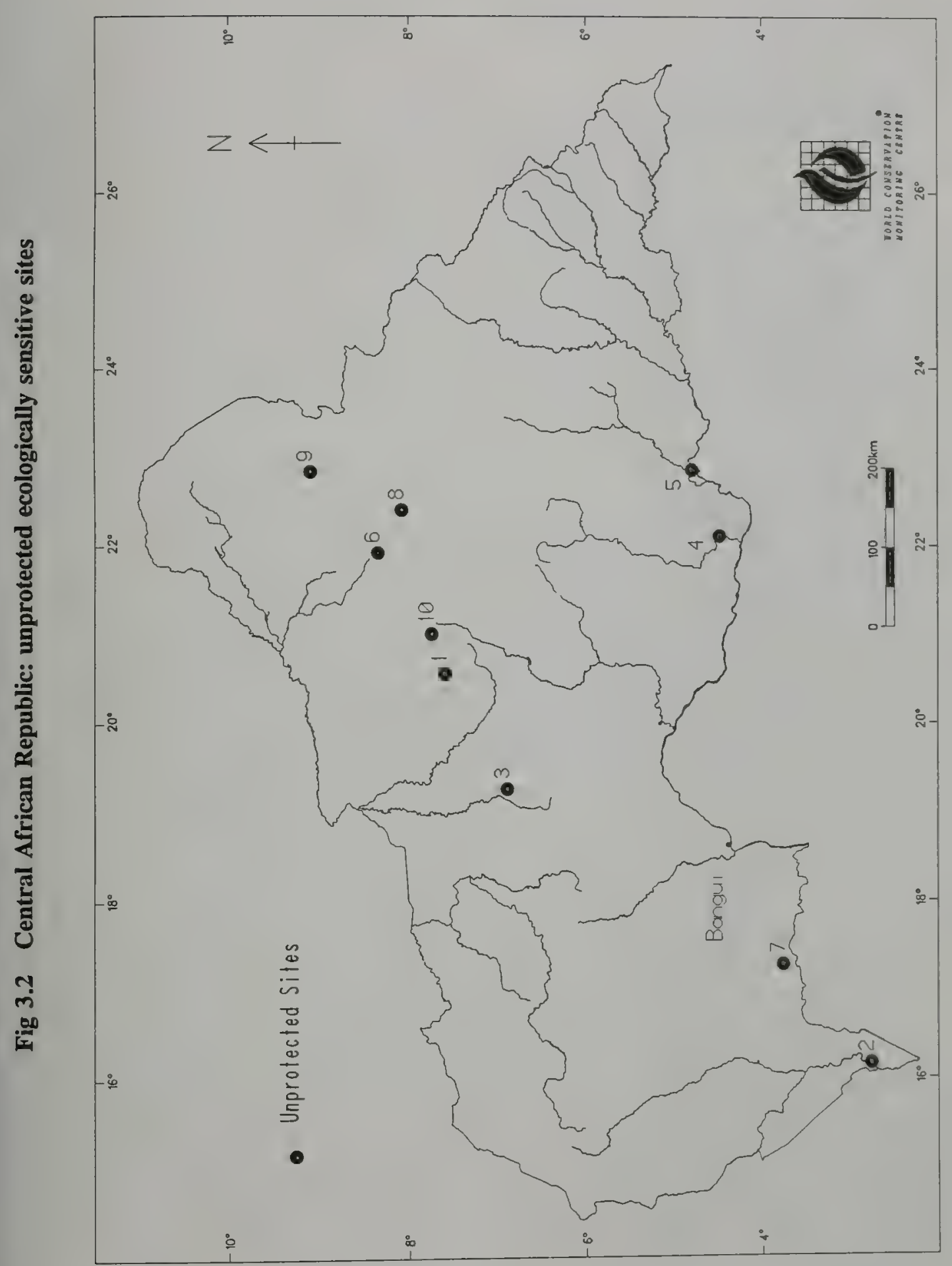




\section{CONGO}

\section{INTERNATIONALLY RECOGNISED PROTECTED AREAS}

Odzala National Park

IUCN Categories II and IX This protected area complex comprises a national park covering $126,600 \mathrm{ha}$ and a biosphere reserve of 110,000 ha, contiguous to Lekoli-Pandaka Faunal Reserve $(68,200 \mathrm{ha})$ and M'boko Hunting Reserve $(90,000 \mathrm{ha})$. Situated on an undulating plateau with many natural saltpans, the area is mostly covered with dense evergreen and some secondary forest, with savanna on hilltops. The typical forest fauna includes threatened species such as leopard, gorilla Gorilla gorilla, and chimpanzee Pan troglodytes. The rare giant African swallowtail Papilio antimachus occurs. Poaching, particularly of elephant, has been reported, as well as of gorilla and chimpanzee. Some pygmies have temporary camps within the park. Lack of access, equipment and staff (staff are stationed outside the park), means the park is not adequately patrolled. The park has never been developed and there is no tourism, as access is fairly limited (IUCN/UNEP, 1987; MacKinnon and MacKinnon, 1986).

Dimonika Biosphere Reserve

IUCN Category IX This reserve of 136,000 ha comprises a central zone of $91,000 \mathrm{ha}$, buffer zones of $20,000 \mathrm{ha}$ and $7000 \mathrm{ha}$, and a "zone of influence" of $18,000 \mathrm{ha}$. It is situated in rugged mountain ranges parallel to the coast, and its forests protect an important watershed, crucial to an area stretching as far as the coast. The flora is particularly interesting, existing in a transitional zone between evergreen and semi-deciduous forest. Various types of regenerating forest occur. The rich and varied fauna includes a number of primates and antelopes, and several threatened species. Nearly 8000 people live near the reserve, not including a further 664 persons resident in the buffer zone, which suffers from human pressure as a result. An area of 23,500 ha within the core area was commercially logged until 1992 . Illegal hunting by gold prospectors is known to take place, and illegal cultivation puts constant pressure on the buffer zone (IUCN, 1989; IUCN/UNEP, 1987).

\section{NATIONALLY PROTECTED AREAS}

\section{Conkouati Faunal Reserve}

IUCN Category IV The reserve covers 144,294 ha in a low-lying coastal area, comprising sandy beaches, areas of mangrove and several lagoons connected to the Atlantic Ocean. Scrub and dense humid forest occur inland. The reserve supports a number of threatened mammals, including chimpanzee Pan troglodytes, mandrill Mandrillus sphinx, manatee and gorilla Gorilla gorilla. However, lack of finance and sufficient staff to control poaching has led to a noticeable decline in animal numbers. There is still a significant human population within the reserve, and timber felling is gradually reducing the size of the forest patches. Timber exploitation was renewed in 1988, and oil and potassium exploration are causing disturbance. It is hoped that a marine area can be added to the reserve, but funds are lacking (IUCN, 1989; IUCN/UNEP, 1987). 
Lefini Faunal Reserve

IUCN Category IV

This reserve of $630,000 \mathrm{ha}$ is situated on the vast Bateke sandstone plateau, dissected to depths of $200-300 \mathrm{~m}$ by the Léfini and Nambouli rivers, forming some spectacular canyons. Fires have reduced the formerly dense dry forest to a few isolated patches surrounded by open grassland savanna, with some gallery forest along the rivers. The fauna is much reduced, but still includes elephant and several duiker species and a diverse avifauna. Poaching, particularly of lion and elephant, have caused their disappearance from some areas; guard posts are too far apart, and staff and equipment scarce. Five villages exist within the reserve, and plans to dam part of the Lefini River could flood large areas (IUCN/UNEP, 1987).

\section{Lekoli-Pandaka Faunal Reserve}

IUCN Category IV

The reserve covers $68,200 \mathrm{ha}$, and is part of a larger conservation area that includes M'boko Hunting Reserve $(90,000 \mathrm{ha})$ and Odzala National Park (126,600ha). During the long rainy season up to $60 \%$ of the reserve is flooded, and soils are subject to landslides. An important feature is the reserve's location in a transitional area between the two major vegetation zones of equatorial rainforest and savanna, and there are saltpans which attract many animals. The forest fauna includes the threatened gorilla and forest elephant Loxodonta africana cyclotis. Poaching, particularly of elephant and buffalo at the saltpans, and illegal fishing occur. Access is difficult, and the Lekioli River is used for this purpose. The staff are also responsible for Odzala National Park and no control posts exist (IUCN/UNEP, 1987).

\section{M'boko Hunting Reserve}

IUCN Category IV

This reserve of $90,000 \mathrm{ha}$ is part of a larger conservation area that includes Lekoli-Pandaka Faunal Reserve $(68,200 \mathrm{ha})$ and Odzala National Park $(126,600 \mathrm{ha})$ and comprises the upper floodplain of several tributaries of the Congo River. Vegetation types include scattered tree savanna and dense humid equatorial rain forest, although the forest has been reduced to relatively impoverished secondary forest in areas where timber has been extracted. The reserve supports a number of ungulates and some elephant. Hunting is allowed under permit, but access is difficult. Poaching for ivory by foreigners as well as locals occurs, but there is only one staff member on the reserve (IUCN/UNEP, 1987).

\section{Mont Fouari Faunal Reserve}

IUCN Category IV This area of 15,600 ha is part of an 88,3600 ha conservation area including Mont Mavoumbou Hunting Reserve (42,000ha), Nyanga Nord Faunal Reserve ( $7700 \mathrm{ha})$ and Nyanga Sud Hunting Reserve (23,000ha), incorporating a seasonally flooded plain and numerous marshes including Lac Bleu, which is fed by groundwater. Most of the reserve is moderately wooded savanna, while a tenth of the area, including Mt Fouari, supports a fairly dense Terminalia superba forest. Fauna includes several duiker species, and large animals are more numerous here than in other Congo reserves, making it popular with visitors. Poaching, the collection of forest products and periodic fires are threatening the ecosystem (IUCN/UNEP, 1987). 
Mont Mavoumbou Hunting Reserve

IUCN Category IV This reserve of $42,000 \mathrm{ha}$ is part of an $88,300 \mathrm{ha}$ conservation area that includes Nyanga Nord Faunal Reserve (7700ha), Nyanga Sud Hunting Reserve $(23,000 \mathrm{ha})$ and Mont Fouari Faunal Reserve $(15,600 \mathrm{ha})$. The dominant feature is Mount Mavoumbou, which forms the southern boundary. Most of the area is vegetated by wooded savanna, but isolated forest patches occur. Larger mammals are similar to those in Mont Fouari Faunal Reserve and include elephant, buffalo and several ungulate species. Poaching, the collection of forest products, encroachment of cultivation and indiscriminate fires threaten the integrity of the reserve, which enjoys limited surveillance. Guard posts have been abandoned (IUCN/UNEP, 1987).

Nyanga Nord Faunal Reserve

IUCN Category IV

This 7700 ha reserve is part of an 88,300 ha conservation area including Mont Mavoumbou Hunting Reserve $(42,000 \mathrm{ha})$, Mount Fouari Faunal Reserve (15,600ha) and Nyanga Sud Hunting Reserve $(23,000 \mathrm{ha})$; it is separated from Nyanga Sud by the Nyanga River. Notable landforms are the narrow Mitsoubou Gorge and the deep Lac Tsoubou. Much of the area is vegetated with tall-grass savanna in low-lying areas, with shorter grass on slopes and limited areas of gallery forest. Larger mammals that survive in the reserve include several antelope species, but poaching and periodic fires are a problem (IUCN/UNEP, 1987).

Nyanga Sud Hunting Reserve

IUCN Category IV

This reserve covers an area of $23,000 \mathrm{ha}$, and is part of an $88,300 \mathrm{ha}$ conservation area with Nyanga Nord Faunal Reserve (7700ha), Mont Mavoumbou Hunting Reserve (42,000ha) and Mont Fouari Faunal Reserve (15,600ha) and separated from Nyanga Nord by the Nyanga River. Nearly all the reserve is well-wooded savanna, with areas of secondary forest noted for stands of Terminalia superba. Larger mammals in the reserve include several antelope species, but poaching, the collection of forest products, illegal felling (particularly of Terminalia), and fires in the savanna areas, threaten the integrity of the reserve. Hunting is permitted under license (IUCN/UNEP, 1987).

Tsoulou Faunal Reserve

IUCN Category IV

This reserve of 30,000 ha includes a series of calcareous hills, mostly vegetated by savanna with secondary forest along rivers. A variety of mammals occur, including gorilla and elephant. However, surveillance is poor and poaching, periodic fires and illegal fishing are common, as the reserve is under pressure from the expanding local population around it (IUCN/UNEP, 1987).

\section{OTHER MANAGED SITES}

\section{Loudima Faunal Reserve}

The reserve covers 6000 ha of predominantly savanna. Plantations of eucalyptus and pine trees exist, which are harvested. Mammals include buffalo, bushpig and several monkey species. The pines provide shelter for savanna fauna and are apparently considered to be of value in the management of the area. The whole area only has one 
guard to control hunting, and no control post. Night poaching and fires are a threat (IUCN/UNEP, 1987).

\section{UNPROTECTED AREAS}

\section{Boko-Songo (Aubeville) Forest}

$4^{\circ} 16^{\prime} \mathrm{S}, 13^{\circ} 18^{\prime} \mathrm{E}$ A new reserve is deemed necessary in this area (Stuart et al., 1990)

\section{Bowé de Kouyi Forest}

$2^{\circ} 27^{\prime} \mathrm{S}, 12^{\circ} 26^{\prime} \mathrm{E}$ Situated on the central slopes of the Chaillu Massif, this forested area incorporates two large plateau areas between $600 \mathrm{~m}$ and $650 \mathrm{~m}$, deeply dissected by forested dolines. The fauna has been little studied. The site is considered to be of scientific importance, and should be protected (IUCN, 1989; Stuart et al., 1990).

\section{Grand Bangou Forest}

$3^{\circ} 50^{\prime}-3^{\circ} 58^{\prime} \mathrm{S}, 14^{\circ} 23^{\prime}-14^{\circ} 32^{\prime} \mathrm{E}$ This site consists of semi-humid primary and secondary forests, covering an area of about 13,000 ha between $300 \mathrm{~m}$ and $500 \mathrm{~m}$ elevation. Forest fauna such as buffalo, sitatunga, duikers and monkeys occur, but the area has not been fully studied. It is considered to be biologically interesting. Human settlement is low, but subsistence activities take place (IUCN, 1987; IUCN, 1990a; Stuart et al., 1990).

\section{Ibenga-Motaba Forest}

$2^{\circ} 23^{\circ}-3^{\circ} 12^{\prime} \mathrm{N}, 16^{\circ} 52^{\prime}-18^{\circ} 10^{\prime} \mathrm{E}$ This is an area of about $661,196 \mathrm{ha}$ covered by partially deciduous forest, swamp forest, Gilbertiodendron rain forest and swampy areas with Raphia palms. The fauna has not been well studied, but includes elephant, gorilla, chimpanzee, duiker and leopard. It is recommended as a protected area. Human population is low (IUCN, 1989; Stuart et al., 1990).

\section{Intsini and Manières}

This site supports mixed forest and savanna (IUCN, 1987).

\section{Kéllé-Oboko II Forest}

A reserve is needed at this site, south of Kélle (Stuart et al., 1990).

\section{Lac Télé Region}

$0^{\circ} 00^{\prime}-2^{\circ} 00^{\prime} \mathrm{N}, 16^{\circ} 43^{\prime}-17^{\circ} 33^{\prime} \mathrm{E}$ This area incorporates moist forest covering about $1,050,000 \mathrm{ha}$ between $280 \mathrm{~m}$ and $380 \mathrm{~m}$, and includes Lac Télé $(5-6 \mathrm{~km}$ in diameter). Fauna includes DeBrazza's monkey Cercopithecus neglectus, Pennant's red colobus Procolobus pennanti, Cercocebus agilis, sitatunga, chevrotain, black-fronted duiker, otters, elephant and buffalo. Human population density is low, and the area is recommended for protection (IUCN, 1989; IUCN, 1987; Stuart et al., 1990). 


\section{Likouala-aux-herbes-Lac Télé - see Lac Télé Region}

\section{Londéla-Kayes Forest}

$4^{\circ} 48^{\prime} \mathrm{S}, 13^{\circ} 25^{\prime} \mathrm{E}$ A new reserve is necessary in this area (Stuart et al., 1990).

\section{Malebo Pool, Stanley Pool}

$4^{\circ} 20^{\prime} \mathrm{S}, 15^{\circ} 30^{\prime} \mathrm{E}$ Situated on the border with Zaire immediately to the north of Kinshasa and Brazzaville, this lake is situated on the Zaïre River and covers 50,000ha; it incorporates the large Mbamou Island. Over 2.35 species of fish have been recorded, seven of which are probably endemic. Hippopotamus, bushpig, sitatunga, water mongoose and otter occur (Burgis and Symoens, 1987).

\section{Mambili Forest}

This is the sole locality for the dragonfly Aethiothemis watuliki (Stuart et al., 1990).

\section{Mbombo-Sembe}

A new reserve is considered to be necessary (Stuart et al., 1990).

\section{Mboukou-Djeke}

A new reserve is considered to be necessary (Stuart et al., 1990).

\section{Mont Nabemba-Garabinzam}

$1^{\circ} 10^{\prime}-2^{\circ} 00^{\prime} \mathrm{N}, 13^{\circ} 00^{\prime}-14^{\circ} 00^{\prime} \mathrm{E}$ This area covers an estimated area of $395,000 \mathrm{ha}$ of forested lowland between $400 \mathrm{~m}$ and $600 \mathrm{~m}$, and incorporates mountains between $600 \mathrm{~m}$ and $1000 \mathrm{~m}$. Mont Nabemba possesses a rich and important flora, and although the fauna of the area is poorly documented, gorilla, bongo and chevrotain are known to occur. The area is strongly recommended for protection (IUCN, 1989; Stuart et al., 1990).

\section{Nouabalé Forest}

$2^{\circ} 10^{\prime}-3^{\circ} 00^{\prime} \mathrm{N}, 16^{\circ} 10^{\prime}-17^{\circ} 00^{\prime} \mathrm{E}$ This forested area covers about 458,000 ha of North Congo differentiated rain forest on plateaux declining from between $400 \mathrm{~m}$ and $500 \mathrm{~m}$ to $200-400 \mathrm{~m}$ in the south-east. The fauna is rich and includes gorilla, chimpanzee, potto, elephant, duiker, bongo and bushpig. Human population is low, and the area is recommended as a protected area (IUCN, 1989; Stuart et al., 1990).

\section{Ogooué-Zanaga Forest}

$2^{\circ} 44^{\prime} \mathrm{S}, 13^{\circ} 51^{\prime} \mathrm{E}$ A new reserve is considered necessary (Stuart et al., 1990).

\section{Patte d'Oie and Tsiemé Forests}

A reserve is needed in this area (Stuart et al., 1990).

\section{Petit Bangou}

This site supports dry forest worthy of protection (IUCN, 1987).

\section{Souanke - see Mont Nabemba-Garabinzam}




\section{CONGO - PROTECTED SITES}

National/international designations

Name of area and

map reference (see Fig. 4.1)

Management

area (ha)

144,294

630,000

68,200

15,600

7,700

30,000

90,000

42,000

23,000

126,600

10 Odzala

Biosphere Reserves

Parc national d'Odzala

Réserve de la Biosphère de Dimonika
1977

136,000

1988
110,000
1940

Year

notified

1980

1951

1955

1958

1958

1963

1955

1955

1958 
Fig 4.1 Congo: protected ecologically sensitive sites

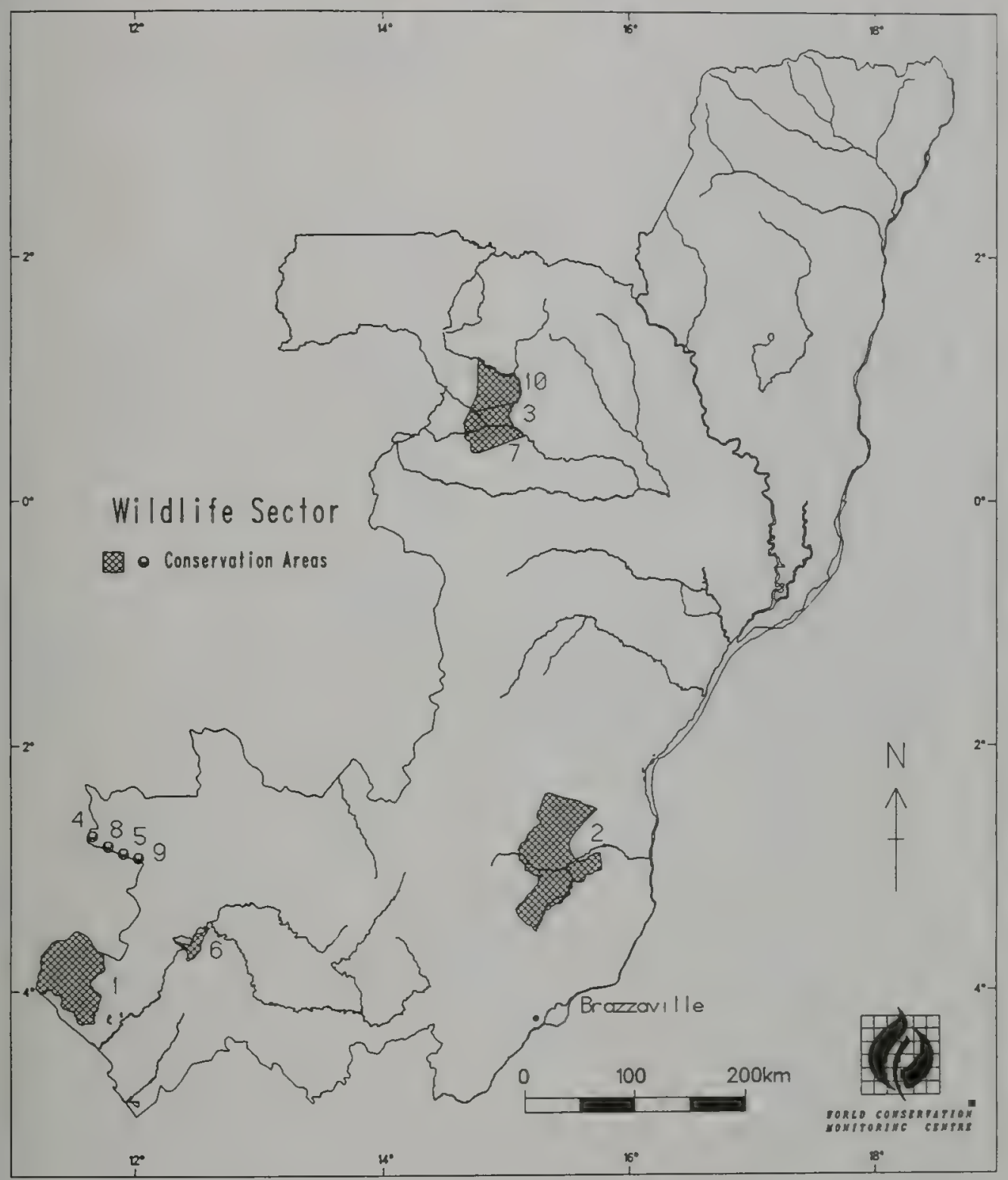




\section{CONGO - UNPROTECTED SITES}

Name of area and

map reference (see Fig. 4.2)

1 Boko-Songo (Aubeville) Forest

2 Bowé de Kouyi Forest

3 Grand Bangou Forest

4 Ibenga-Motaba Forest

Intsini and Manières

Kéllé-Oboko II Forest

5 Lac Télé Region

6 Kouilou Estuary Mangroves

7 Londéla-Kayes Forest

8 Malebo Pool, Stanley Pool

Mambili Forest

Mbombo-Sembe

Mboukou-Djeke

9 Mont Nabemba-Garabinzam

10 Nouabalé Forest

11 Ogooué-Zanaga Forest

Patte d'Oie and Tsiemé Forests

Petit Bangou
Management

area (ha)

13,000

661,196

$1,050,000$

50,000

395,000 
Fig 4.2 Congo: unprotected ecologically sensitive sites

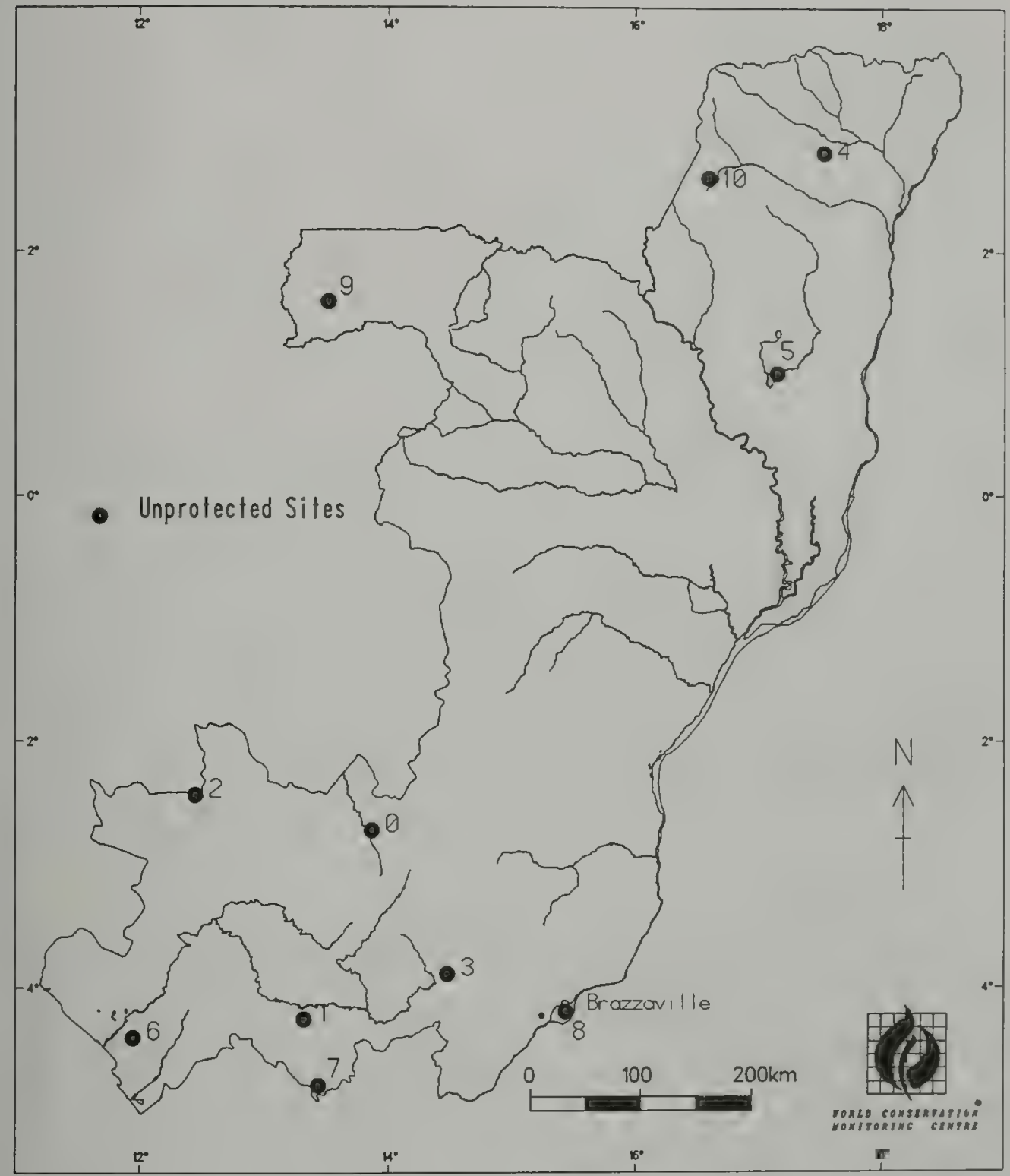





\section{COTE D'TVOIRE}

\section{INTERNATIONALLY RECOGNISED SITES}

\section{Comoé National Park}

IUCN Categories II, IX and X This large park of $1,150,000$ ha is also a biosphere reserve and World Heritage site. It is important for the wide variety of its habitats, transitional between open woodland and savanna and including all major types of savanna found in this region. The infertile soils are unsuitable for cultivation, and in general the area has been little modified. A large number of mammals occur, with 11 species of monkey (including chimpanzee) and 17 species of carnivore, including lion and leopard. Comoé forms the northern limit of distribution for some antelope species, and all three species of African crocodile occur. Poaching has been reduced by anti-poaching measures, but there is a small village within the park, and limited cultivation, burning and grazing (IUCN/UNEP, 1987; MacKinnon and MacKinnon, 1986).

Mont Nimba Strict Nature Reserve

IUCN Categories I and X Mount Nimba, the third highest mountain $(1752 \mathrm{~m})$ in West Africa west of Cameroon, lies on the border of three countries: Côte d'Ivoire, Guinea and Liberia. In Côte d'Ivoire 5000ha designated as classified forest comprise the Mont Nimba World Heritage Site. There is a continuum of habitats, from savanna on infertile, iron-rich soils at about $500 \mathrm{~m}$ elevation, through lowland moist rain forest and dry mid-altitude forest, to high altitude grassland on the summits. The area has been identified as a centre of plant diversity under the IUCN-WWF Plants Conservation Programme. The fauna includes several threatened species such as pygmy hippopotamus Choeropsis liberiensis, leopard, chimpanzee and white-necked rockfowl Picathartes gymnocephalus. The Liberian section is still not protected; poaching occurs there and massive iron ore mining operations are in progress, as the whole mountain is rich in iron ore (IUCN/UNEP, 1987).

\section{Taï National Park}

IUCN Categories II, IX and X This park of $350,000 \mathrm{ha}$ is also a Biosphere Reserve and World Heritage Site. It is one of the largest remaining portions of the Upper Guinea rain forest bloc, which once stretched from Sierra Leone to Ghana. It has a high level of plant endemism, and much ancient growth; 47 of the 54 species of large mammal found in Upper Guinea forests occur there, including five threatened species. Of the avifauna of over 230 species, five are threatened. Tai is in the top ten forests of conservation importance in Africa (Collar and Stuart, 1988). Some exploitation is allowed in the buffer zone (covering an additional 20,000ha); extensive felling has occurred in the south, and crop cultivation is taking place. A perimeter road, designed to define boundaries, has had the adverse effect of increasing access to the area. Gold panning also severely affects parts of the central area. Poaching and disturbance have reduced some animal populations, especially forest elephant. Problems increased in the absence of stringent protection, but this is now being strongly enforced and boundaries clearly delimited (IUCN/UNEP, 1987; MacKinnon and MacKinnon, 1986). 


\section{NATIONALLY PROTECTED AREAS}

Azagny National Park

IUCN Category II A coastal park of 19,000 ha situated between the Bandama River and Ebrie Lagoon; about two-thirds is covered with various types of swamp. The naturally fluctuating water levels are also artificially maintained. Habitats include a small area of mangroves, groundwater forest with many palms, and coastal savanna. It supports many threatened species, including chimpanzee, West African manatee Trichechus senegalensis, elephant and the three African species of crocodile. The important animal species within the park are not numerous and are isolated from other populations, as the park is surrounded by developed land. Population increase is also putting pressure on the park, and oil exploration is reported (IUCN/UNEP, 1987).

\section{Banco National Park}

IUCN Category II This is an isolated remnant of dense rain forest covering $3000 \mathrm{ha}$, situated on a coastal lagoon at the mouth of the River Banco. It contains the national forestry college and an arboretum; a few plantations, mainly of teak, have been established in cleared areas. The fauna is not abundant, but includes several monkey species although chimpanzee are reported to have disappeared. The park's integrity is safeguarded at present but, being only $10 \mathrm{~km}$ west of Abidjan, it has large numbers of visitors and is affected by poaching and road development (IUCN/UNEP, 1987).

Divo Botanical Reserve

IUCN Category IV $5^{\circ} 51^{\prime} \mathrm{N}, 5^{\circ} 15^{\prime} \mathrm{W}$ Established in 1975 , this reserve lies in the Divo District of Southwest Region, east of Divo town. It supports dense deciduous forest, covering 7350 ha (Frame, 1987).

Haut Bandama Fauna and Flora Reserve

IUCN Category I A flat area of $123,000 \mathrm{ha}$, consisting of very open savanna woodland and gallery forest. The area is considered particularly important for the protection of the savanna form of elephant, and is the only refuge for hippopotamus when they leave Lake Kossou (to the south) to graze. The boundaries are not delimited, and poaching in the past has severely reduced animal populations, which are now recovering. The area of the reserve was reduced in 1974 to make way for agro-industrial developments, and a sugar plantation threatens the south-east part (IUCN/UNEP, 1987).

\section{Iles Ehotile National Park}

IUCN Category II $5^{\circ} 06^{\prime} \mathrm{N}, 3^{\circ} 13^{\prime} \mathrm{W}$ Established in 1974 , this protected area covers 10,500 ha of the southern half of the main Abi Lagoon, east of Abidjan.

Marahoue National Park

IUCN Category II Covering $101,000 \mathrm{ha}$, this park includes dense deciduous forest, gallery forest and Guinea savanna; a number of inselbergs support their own characteristic vegetation. The fauna includes both forest and savanna species, including several primates including chimpanzee, and about 50 elephant occur. Numbers of many species are low due to heavy poaching in the past, but recovery has begun. Fish poisoning by 
fertilizers takes place, and there may be adverse effects from spraying against tsetse flies. There is well developed tourism all year, illegal plantations and forest exploitation (IUCN/UNEP, 1987).

Mont Peko National Park

IUCN Category II Most of the 34,000 ha of this park, which is situated in a mountainous region, is covered by dense deciduous forest; about a fifth consists of Guinea savanna woodland. It supports a varied fauna including threatened species such as chimpanzee, leopard and elephant. The park is now well protected against poaching, but agriculture takes place and mining may also affect the area (IUCN/UNEP, 1987).

Mont Sangbe National Park

IUCN Category II This park covers an area of 95,000 ha in the Toura Mountains, which have 14 peaks over $1000 \mathrm{~m}$ high. Guinea savanna woodland predominates, with a number of endemic plant species. The varied and abundant fauna includes elephant, but poaching and forest exploitation do occur (IUCN/UNEP, 1987).

N'Zo Partial Faunal Reserve

IUCN Category IV A flat, low-lying area of $95,000 \mathrm{ha}$, contiguous to Tai National Park, to which it is similar and for which it acts as a buffer zone. The vegetation comprises Upper Guinean dense evergreen rain forest similar to that of the Tai forest. The fauna is similar to that of Taii, and includes pygmy hippopotamus and Jentink's duiker. Exploitation of some forest products is permitted, which makes it difficult to control other activities, including poaching. Tree felling is now greatly diminished (IUCN/UNEP, 1987).

\section{OTHER MANAGED AREAS}

Abounderessou Classified Forest

IUCN Category VIII In Bouaflé District of the Central Region; forest-savanna mosaic, covering 3200ha (Frame, 1987).

Ahua Classified Forest

IUCN Category VIII In Dimbokro District of the Central Region; dense forest (deciduous), covering 2400 ha (Frame, 1987).

\section{Akabo Classified Forest 2300ha}

Anguededou Classified Forest

IUCN Category VIII This is dense evergreen forest covering 840 ha in the Abidjan District of the South-east Region (Frame, 1987).

Badenou Classified Forest

IUCN Category VIII In Korhogo District of the North-west Region; Sudanese savanna covering 28,300ha (Frame, 1987).

IUCN Category VIII 
Badikaha Classified Forest

IUCN Category VIII

In Katiola District of Central Region, and Ferkessedougou District of North-east Region; Sudanese savanna vegetation, with African buffalo (Frame, 1987).

Bafing Classified Forest

IUCN Category VIII

In Touba and Bian Kouma Districts of North-west Region; forest-savanna mosaic covering 2200ha (Frame, 1987).

Bamo Classified Forest

IUCN Category VIII In Abengourou District of South-east Region; dense forest (deciduous), covering $250 \mathrm{ha}$ (Frame, 1987).

Bamoro Classified Forest

IUCN Category VIII

In Bouake District Central Region; Guinea savanna covering 2200ha (Frame, 1987).

Bandama Supérieur Classified Forest

IUCN Category VIII

In Ferkessedougou District of North-east Region; Sudanese savanna covering 45,000ha. African buffalo are seasonally present (Frame, 1987).

Bandama-Blanc Classified Forest

50,500 ha

IUCN Category VIII

Baya-Korore Classified Forest

IUCN Category VIII

In Bondoukou District of the Central Region; dense forest (deciduous), covering 12,200ha. African buffalo are present (Frame, 1987).

Belefima Classified Forest

IUCN Category VIII In Bouna District of North-east Region; Sudanese savanna covering 22,800ha. An important reserve for elephant. Buffalo are also present (Frame, 1987).

\section{Besse Boka Classified Forest - see Fetekro Classified Forest}

Besso Classified Forest

IUCN Category VIII

In Adzope District of the South-east Region; dense forest (deciduous), covering 23,100ha. Buffalo occur (Frame, 1987).

Biki-Bossematie Classified Forest

IUCN Category VIII

In Aboisso District of the South-east Region; dense forest (deciduous) covering 38,900ha. An important reserve for elephant. Buffalo also occur (Frame, 1987).

Boka-Go Classified Forest

IUCN Category VIII In Bouake District of the Central Region; Guinea savanna covering 4900 ha. Buffalo occur (Frame, 1987). 
Bolo Classified Forest

IUCN Category VIII

In Sassandra District of South-west Region; dense forest (evergreen), covering 8800ha. Buffalo occur (Frame, 1987).

Borotou Classified Forest

IUCN Category VIII

$8^{\circ} 44^{\prime} \mathrm{N}, 7^{\circ} 27^{\prime} \mathrm{W}$ In Touba District of North-west Region; Sudanese savanna covering 10,400ha. An important reserve for elephant. Buffalo are also present (Frame, 1987).

Bouafle Classified Forest

IUCN Category VIII In Bouaflé District of Central Region; dense forest (deciduous) covering 20,350ha. Buffalo occur, and the reserve is well-suited for managing this species (Frame, 1987).

Brassue Classified Forest

IUCN Category VIII In Aboisso District of South-east Region; dense forest (deciduous), covering 20,000ha. Buffalo are seasonally present (Frame, 1987).

Comoe Classified Forest

IUCN Category VIII In Abidjan District of South-east Region; dense forest (evergreen), covering 1600 ha. Buffalo are seasonally present (Frame, 1987).

Davo Classified Forest

IUCN Category VIII In Gagnoa District of South-west Region; dense forest (deciduous) covering 12,580ha. Buffalo are present (Frame, 1987).

Dents de Man Classified Forest 136ha

IUCN Category VIII

Diambarakrou Classified Forest

IUCN Category VIII In Aboisso District of the South-east Region; dense forest (deciduous) covering 27,350ha. Buffalo are present (Frame, 1987).

Divo Classified Forest

7350 ha

IUCN Category VIII

Dogodou Classified Forest

IUCN Category VIII $5^{\circ} 22^{\prime} \mathrm{N}, 5^{\circ} 22^{\prime} \mathrm{W}$ In Divo District of the South-west Region, north-west of Azagny National Park. Dense evergreen forest, covering 22,400ha; an important reserve for elephant, and buffalo are present (Frame, 1987).

Doka Classified Forest

IUCN Category VIII $6^{\circ} 19^{\prime} \mathrm{N}, 5^{\circ} 17^{\prime} \mathrm{W}$ In Oueme District of South-west Region; dense deciduous forest, covering 14,400ha. Buffalo occur (Frame, 1987).

Doubele Classified Forest

IUCN Category VIII

4300ha 
Duékoué Classified Forest

IUCN Category VIII $6^{\circ} 38^{\prime} \mathrm{N}, 7^{\circ} 08^{\prime} \mathrm{W}$ In Guiglo District of West Region; dense forest (deciduous) covering 47,600ha. Buffalo occur (Frame, 1987).

Dyengele Classified Forest

IUCN Category VIII In Odienne District of North-west Region; Sudanese savanna covering 2600ha (Frame, 1987).

Fetekro Classified Forest

IUCN Category VIII

$7^{\circ} 48^{\prime} \mathrm{N}, 4^{\circ} 43^{\prime} \mathrm{W}$ In Bouake District of Central Region; Guinea savanna covering $4800 \mathrm{ha}$. An important reserve for elephant, and buffalo are present seasonally. The reserve is well suited for managing buffalo in coordination with Laka, Mafa and Besse Boka forest reserves, which combined would total an area of 31,600ha (Frame, 1987; Stuart et al. 1990).

Flan Soblysiemen Classified Forest

IUCN Category VIII In Man District of West Region; forest-savanna mosaic covering 16,700ha. Buffalo occur (Frame, 1987).

Go-Bodienou Classified Forest

IUCN Category VIII In Abidjan District of South-east region and Divo District of the Central region; dense forest (evergreen) covering $60,000 \mathrm{ha}$. An important area for elephant and buffalo occur (Frame, 1987).

Goin-Cavally Classified Forest 189,900 ha

IUCN Category VIII

Gorke Classified Forest

IUCN Category VIII In Abengourou District of South-east Region; dense forest (deciduous) covering 4100ha (Frame, 1987).

Goudi Classified Forest

IUCN Category VIII In Divo District of South-west Region; dense forest (deciduous) covering 9600 ha (Frame, 1987).

Gouele Classified Forest

11,600 ha

IUCN Category VIII

Goulaleu Classified Forest

IUCN Category VIII In Guiglo District of West Region; dense forest (deciduous) covering 950ha. Buffalo are seasonally present (Frame, 1987).

Guinteguela Classified Forest IUCN Category VIII In Touba District of North-west Region; Sudanese savanna covering 9600 ha. Buffalo occur (Frame, 1987). 
Hana Classified Forest

IUCN Category VIII

In Soubre District of South-west Region; dense forest (evergreen) covering 72,000ha. Buffalo are present (Frame, 1987).

Haute Dodo Classified Forest

IUCN Category VIII

In Sassandra District of South-west Region; dense forest (evergreen) covering 109,400ha. An important reserve for elephant, and buffalo occur. Reserve well suited for managing buffalo (Frame, 1987).

Haut-Bandama Classified Forest 84,000 ha

IUCN Category VIII

Haut-Sassandra Classified Forest

IUCN Category VIII In Daloa District of West Region; dense forest (deciduous) covering 102,400ha. An important reserve for elephant, and buffalo occur. The reserve is well suited for managing buffalo (Frame, 1987).

Hein N'Zodji Classified Forest

IUCN Category VIII In Abidjan District of South-east Region; dense forest (evergreen) covering 23,400ha. Buffalo occur (Frame, 1987).

Ira Classified Forest

IUCN Category VIII In Biankouma District of North-west Region; forest-savanna mosaic, covering 13,000ha. Buffalo occur (Frame, 1987).

Irobo Classified Forest

IUCN Category VIII In Abidjan District of South-east Region; dense forest (evergreen), covering 24,500ha. Buffalo occur (Frame, 1987).

Kanhasso Classified Forest

IUCN Category VIII In Odienne District of North-west Region; Sudanese savanna covering 5900ha (Frame, 1987).

Kani-Bandama Rouge Classified Forest

IUCN Category VIII 105,000ha

Kanoumou Classified Forest

IUCN Category VIII $4000 \mathrm{ha}$

Kassa Classified Forest

IUCN Category VIII In Abidjan District of South-east Region; dense forest (deciduous) covering 7000 ha (Frame, 1987).

Kere Classified Forest

IUCN Category VIII In Odienne District of North-west Region; Sudanese savanna covering 1200ha (Frame, 1987). 
Keregbo Classified Forest

IUCN Category VIII In Dimbokro and Bouake Districts of Central Region; dense forest (deciduous) covering $21,300 \mathrm{ha}$. An important reserve for elephant, and buffalo also occur. The reserve is suitable for buffalo management (Frame, 1987).

Kimbrila Classified Forest

IUCN Category VIII In Odienne District of North-west Region; Sudanese savanna covering 1100ha (Frame, 1987).

Kinkene Classified Forest

IUCN Category VIII In Dabakala District of Central Region; Sudanese savanna covering 45,300ha. The reserve is important for elephant and buffalo, and well-suited for management (Frame, 1987).

Kiohan Classified Forest

IUCN Category VIII

In Katiola District of Central Region; Sudanese savanna, covering 1500ha (Frame, 1987).

Koba Classified Forest

31,430 ha

IUCN Category VIII

Koba Nord Classified Forest

IUCN Category VIII

In Seguela and Mankono Districts of North-west Region; Sudanese savanna covering 2600ha. Buffalo occur (Frame, 1987).

Kobo Classified Forest

IUCN Category VIII

In Katiola District of Central Region; Sudanese savanna, covering 14,200ha (Frame, 1987).

Kogaha Classified Forest

IUCN Category VIII

In Katiola District of Central Region; Sudanese savanna, covering 15,900ha (Frame, 1987).

Korhogo Classified Forest

IUCN Category VIII

In Korhogo District of North-west Region; Sudanese savanna covering 1600 ha (Frame, 1987).

Korondekro Classified Forest

700 ha

IUCN Category VIII

Kouaba-Boka Classified Forest

IUCN Category VIII

In Bouake District of Central Region; Guinea savanna covering 3200 ha. Buffalo occur (Frame, 1987). 
Kouin Classified Forest

IUCN Category VIII

In Man District of West Region; dense forest (deciduous), covering 5000ha. Buffalo occur (Frame, 1987).

Koumo-Kafaka Classified Forest

IUCN Category VIII In Dimboklrou District of Central Region; forest-savanna mosaic covering $9000 \mathrm{ha}$. Buffalo occur (Frame, 1987).

Kouroukouna Classified Forest

IUCN Category VIII In Katiola District of Central Region; Sudanese savanna covering $3200 \mathrm{ha}$. Buffalo occur (Frame, 1987).

Kroziale Classified Forest

IUCN Category VIII In Danane District of West Region; dense forest (deciduous), covering 9300ha. Buffalo are present seasonally (Frame, 1987).

Lahouda Classified Forest

IUCN Category VIII In Oueme District of South-west Region; dense forest (deciduous) covering 3960ha. Buffalo are present (Frame, 1987).

\section{Laka Classified Forest - see Fetekro Classified Forest}

Leraba Classified Forest

IUCN Category VIII In Ferkessedougou District of North-east Region; Sudanese savanna, covering 23,500ha. Buffalo occur (Frame, 1987).

Logahan Classified Forest

IUCN Category VIII In Ferkessedougou District of North-east Region; Sudanese savanna covering 2500 ha (Frame, 1987).

Loho Classified Forest

IUCN Category VIII In Katiola District of Central Region; Sudanese savanna covering 92,100ha. An important reserve for elephant, and buffalo also occur. The reserve is suitable for management (Frame, 1987).

Lokpoho Classified Forest

IUCN Category VIII

In Ferkessedougou District of North-east Region; Sudanese savanna, covering 3400ha (Frame, 1987).

Loviguie Classified Forest

IUCN Category VIII

In Abengourou District of South-east Region; dense forest (evergreen), covering 2800ha (Frame, 1987).

Maby Classified Forest

IUCN Category VIII

$63,100 \mathrm{ha}$ 


\section{Mafa Classified Forest - see Fetekro Classified Forest} 13,400

Mando Classified Forest

IUCN Category VIII

In Baouke District of Central Region; dense forest (deciduous), covering 11,300ha. Buffalo occur (Frame, 1987).

Manzan Classified Forest

IUCN Category VIII

In Aboisso District of South-east Region; dense forest (deciduous), covering 4500 ha.

Buffalo are seasonally present (Frame, 1987).

Matiemba Classified Forest

IUCN Category VIII

In Bouake District of Central Region; dense forest (deciduous), covering 960ha. Buffalo occur (Frame, 1987).

Miniabo Classified Forest

600 ha

IUCN Category VIII

Monoga Classified Forest

IUCN Category VIII

In Sassandra District of South-west Region; dense forest (evergreen), covering 35,000 ha. Buffalo are seasonally present (Frame, 1987).

Mont Ba Classified Forest

IUCN Category VIII

In Biankouma District of North-west Region; forest-savanna mosaic, covering 4500ha.

Buffalo occur (Frame, 1987).

Mont Bableu Classified Forest

IUCN Category VIII In Man District of West Region; forest-savanna mosaic covering 15,400ha. Buffalo are seasonally present (Frame, 1987).

Mont Gbande Classified Forest

IUCN Category VIII In Odienne District of North-west Region; Sudanese savanna covering 23,100ha. An important reserve for elephant, and buffalo are present. The reserve is well suited for management (Frame, 1987).

Mont Glo Classified Forest

IUCN Category VIII In the Man District of West Region; dense forest (deciduous), covering 14,000ha. Buffalo are seasonally present (Frame, 1987).

Mont Ko Classified Forest

IUCN Category VIII In Seguela District of North-west Region; Sudanese and Guinea savannas, covering 49,000ha. Buffalo are present. The forest is suitable for management (Frame, 1987). 
In Biankouma District of North-west Region; forest-savanna mosaic, covering 37,400ha. Buffalo occur (Frame, 1987).

Mont Toukoui Classified Forest

IUCN Category VIII $7^{\circ} 26^{\prime} \mathrm{N}, 7^{\circ} 38^{\prime} \mathrm{W}$ In Man District of West Region; dense montane forest covering $4200 \mathrm{ha}$. The tree fern Cyathea manniana occurs (Frame, 1987; WCMC, 1989b).

Mont-Manda Classified Forest

IUCN Category VIII In Odienne District of North-west Region; Sudanese savanna, covering 2800 ha. Buffalo are present seasonally (Frame, 1987).

Mont-Momi Classified Forest

IUCN Category VIII In Danane District of West Region; dense forest (deciduous), covering 8000ha. Buffalo are seasonally present (Frame, 1987).

Mont-Nieton Classified Forest $11,300 \mathrm{ha}$

IUCN Category VIII

Mont-Nimba Classified Forest 19,500ha

IUCN Category VIII

Mont-Tia Classified Forest

IUCN Category VIII In Man District of West Region; dense forest (deciduous), covering 16,300ha. Buffalo occur (Frame, 1987).

Mopri Classified Forest

IUCN Category VIII In Mopri District of South-west Region; dense forest (deciduous), covering 33,000ha. An important reserve for elephant, and buffalo occur. This reserve is especially suitable for the management of buffalo (Frame, 1987).

N'Ganda-N'Ganda Classified Forest

IUCN Category VIII In Agboville District of South-east Region; dense forest (evergreen) and coastal savanna, covering $2400 \mathrm{ha}$. Buffalo are seasonally present (Frame, 1987).

N'Golodougou Classified Forest

IUCN Category VIII In Katiola District of Central Region; Sudanese savanna, covering 4000ha. Buffalo are seasonally present (Frame, 1987).

N'Guechie Classified Forest

IUCN Category VIII In Abidjan District of South-east Region; dense forest (evergreen), covering 2800 ha. Buffalo are present (Frame, 1987). 
N'to Classified Forest

IUCN Category VIII

15,800 ha

Nambon Kaha Classified Forest

3200 ha

IUCN Category VII

Nanyelongo Classified Forest

$600 \mathrm{ha}$

IUCN Category VIII

Niangbon Classified Forest

IUCN Category VIII

In Katiola District of Central Region; Sudanese savanna, covering 1700ha (Frame, 1987).

Niegre Classified Forest

IUCN Category VIII

In Sassandra District of South-west Region; dense forest (evergreen), covering 100,800 ha. An important reserve for elephant, and buffalo also occur. The reserve is suitable for buffalo management (Frame, 1987).

Niouniourou Classified Forest

IUCN Category VIII

In Lakota District of South-west Region; dense forest (evergreen), covering 19,670ha. Buffalo are present seasonally (Frame, 1987).

Nougbo Classified Forest

IUCN Category VIII

In Ferkessedougou District of North-east Region; Sudanese savanna, covering 20,800ha. Buffalo occur. The forest is suited to management (Frame, 1987).

Nyangboue Classified Forest

IUCN Category VIII

In Boundiali District of North-west Region; Sudanese savanna, covering $24,400 \mathrm{ha}$. An important reserve for elephant, and buffalo occur seasonally (Frame, 1987).

Nyellepuo-N'Zi Supérieur Classified Forest

IUCN Category VIII

In Dadakala District of Central Region, and Ferkessedougou District of North-east Region; Sudanese savanna, covering $150,400 \mathrm{ha}$. Buffalo occur, and the reserve is suitable for management (Frame, 1987).

Okromodou Classified Forest

IUCN Category VIII In Sassandra and Divo Districts of South-west Region; dense forest (evergreen), covering 94,500 ha. An important reserve for elephant, and buffalo are also present (Frame, 1987).

Palee Classified Forest

IUCN Category VIII

Poro-Poro Classified Forest

50,500 ha

IUCN Category VIII 

In Dabakala District of Central Region; Sudanese savanna, covering 52,800ha. An important reserve for elephant, and buffalo are present. The reserve is suitable for management (Frame, 1987).

Rapidegrah Classified Forest

IUCN Category VIII In Sassandra District of South-west Region; dense forest (evergreen), covering 204,200ha. Buffalo occur (Frame, 1987).

Rasso Classified Forest

IUCN Category VIII In Abengourou District of South-east Region; dense forest (deciduous), covering 2700ha (Frame, 1987).

Raviart Classified Forest 800 ha

Samankono Classified Forest

IUCN Category VIII In Mankono District of North-west Region; Sudanese savanna, covering 3900ha. Buffalo occur (Frame, 1987).

Sanaimbo Classified Forest IUCN Category VIII In Bongouano District of Central Region; dense forest (deciduous), covering 5200ha (Frame, 1987).

Sananferedougou Classified Forest 470 ha In Oueme, Lakota and Divo Districts of South-west Region; dense forest (deciduous), covering 36,280ha. Buffalo occur (Frame, 1987). 
$32,000 \mathrm{ha}$

In Dimbokro District of Central Region; dense forest (deciduous), covering $3600 \mathrm{ha}$ (Frame, 1987).

Scio Classified Forest

IUCN Category VIII In Guiglo and Man Districts of West Region; dense forest (deciduous), covering 133,800ha. An important reserve for elephant, and buffalo are present. The reserve is suited to buffalo management (Frame, 1987).

Seguela Classified Forest

IUCN Category VIII In Seguela District of North-west Region; forest-savanna mosaic, covering 6300ha. Granite domes occur, with similar vegetation to the Fouta Djalan and consequently of great interest. Buffalo are present (Frame, 1987; WCMC, 1991).

Seguie Classified Forest

IUCN Category VIII In Bongouano District of Central Region; dense forest (deciduous), covering 19,600ha. Buffalo occur (Frame, 1987).

Silue Classified Forest

IUCN Category VIII In Katiola District of Central Region; Sudanese savanna, covering 40,400ha. Buffalo are present (Frame, 1987).

Singrobo Classified Forest

1200ha

IUCN Category VIII

Songan Classified Forest

IUCN Category VIII 31,000ha. An important reserve for elephant, and buffalo occur. The reserve is well suited to buffalo management (Frame, 1987).

Soungourou Classified Forest

IUCN Category VIII In Dimbokro District of Central Region; Guinea savanna, covering 5200ha. Buffalo occur (Frame, 1987).

Suitoro Classified Forest

IUCN Category VIII In Dabakala District of Central Region; Sudanese savanna, covering 22,600ha. An important reserve for elephant, and buffalo occur. The forest is suitable for management (Frame, 1987).

Tafire Classified Forest

IUCN Category VIII In Katiola District of Central Region; Sudanese savanna, covering 8300ha (Frame, 1987). 

In Dimbokro District of Central Region; forest-savanna mosaic, covering 5000ha. Buffalo occur (Frame, 1987).

\section{Tene Classified Forest}

IUCN Category VIII In Oueme District of South-west Region; dense forest (deciduous), covering 29,400ha. Buffalo occur. The forest is suited to buffalo management (Frame, 1987).

\section{Teonle Classified Forest}

IUCN Category VIII In Man District of West Region; dense forest (deciduous), covering 4000ha. Buffalo are present seasonally (Frame, 1987).

Tiapleu Classified Forest

IUCN Category VIII

In Danane District of West Region; dense forest (deciduous), covering 26,700ha. Buffalo are present seasonally (Frame, 1987).

Tieme Classified Forest

IUCN Category VIII In Odienne District of North-west Region; Sudanese savanna, covering 890ha (Frame, 1987).

Tiengala Classified Forest IUCN Category VIII In Katiola District of Central Region; Sudanese savanna, covering 2700 ha. Buffalo are present seasonally (Frame, 1987).

\section{Tienny Classified Forest}

IUCN Category VIII In Odienne District of North-west Region; Sudanese savanna, covering 13,800ha. Buffalo are present (Frame, 1987).

Tindikro Classified Forest

IUCN Category VIII In Odienne District of North-west Region; Sudanese savanna, covering 500ha (Frame, 1987).

Touro Classified Forest

IUCN Category VIII In Bouake District of Central Region; Guinea savanna, covering 580ha (Frame, 1987).

Warigue Classified Forest

IUCN Category VIII In Ferkessedougou District of North-east Region; Sudanese savanna, covering 62,100ha. Buffalo occur (Frame, 1987). 
Yalo Classified Forest

IUCN Category VIII

In Biankouma District of North-west Region; forest-savanna mosaic, covering 26,200ha. Buffalo occur (Frame, 1987).

Yapo Classified Forest

IUCN Category VIII

In Abengourou District of South-east Region; dense forest (evergreen), covering 35,000ha. Buffalo occur (Frame, 1987).

Yaya Classified Forest

IUCN Category VIII

29,400 ha

\section{Zuoke Classified Forest}

IUCN Category VIII

In Oueme District of South-west Region; dense forest (deciduous), covering 9000ha. Buffalo occur (Frame, 1987).

\section{UNPROTECTED SITES}

\section{Aby Lagoon}

$5^{\circ} 18^{\prime} \mathrm{N}, 3^{\circ} 13^{\prime} \mathrm{W}$ A large brackish lagoon fringed by mainly freshwater marshes, Raphia swamp forest and mangroves. The area is of importance to waterfowl; the southern half of the lagoon is within Iles Ehotile National Park (Altenburg 1987).

\section{Ayame Forest}

This forest is typified by the tree Diospyros mapanietum, a vegetation type endemic to this region (WCMC, 1991).

\section{Azuretti Mangroves}

$5^{\circ} 12^{\prime} \mathrm{N}, 3^{\circ} 48^{\prime} \mathrm{W}$ Extensive mangrove and Raphia swamp forests occur around the mouth of the Ebrié lagoon, east of Abidjan. The area is of considerable importance to waterbirds, particularly tern, and supports breeding birds such as little bittern, goliath heron, hamerkop and night heron. It is threatened by activities such as hunting, sand dredging and urbanisation (Altenburg, 1987; WCMC 1989b).

\section{Bandama River Lagoons}

$5^{\circ} 11^{\prime} \mathrm{N}, 5^{\circ} 13^{\prime} \mathrm{W}$ These include the inter-connected brackish lagoons of Tadio, Maké and Tagba. The area includes extensive Rhizophora and Avicennia mangrove forest, Raphia palm swamp forest and freshwater marshes. Of irnportance to waterfowl, especially tern; hunting of terns is a possible threat (Altenburg, 1987).

\section{Basse Dodo}

Intact swamp forests and mangrove forests occur in this area (WCMC, 1991).

\section{Canal d'Asagni Wetlands}

$5^{\circ} 10^{\prime} \mathrm{N}, 3^{\circ} 30^{\prime} \mathrm{W}$ Situated between Grand-Bassam and Iles Ehotile National Park, this area includes about 30,000 ha of swamp forest, with islands of Pandanus and Raphia, and clumps of dense evergreen forest (WCMC, 1991). 


\section{Cape Palmas}

$4^{\circ} 21^{\prime} \mathrm{N}, 7^{\circ} 31^{\prime} \mathrm{W}$ Coral reefs occur off the Cape.

\section{Dagbégo Lagoon}

Intact swamp forests and notable mangrove stands occur, with a diverse fauna (WCMC, 1991).

\section{Fresco Lagoons}

$5^{\circ} 05^{\prime} \mathrm{N}, 5^{\circ} 27^{\prime} \mathrm{W}$ Lying to the west of Fresco, these small lagoons and inlets are fringed by mangroves, freshwater swamps and marshes. They are important for migrant and wintering seabirds, and as breeding grounds for fish and shrimp (WCMC, 1991).

\section{Mankono Region}

Open and closed forest areas occur here (WCMC, 1991).

\section{Mont Kopé a Grabo}

This is an area rich in Afro-montane endemics. The topography inhibits exploitation (WCMC, 1991).

\section{Monts du Toura}

$7^{\circ} 44^{\prime} \mathrm{N}, 7^{\circ} 18^{\prime} \mathrm{W}$ These support a unique form of Guinean savanna north of Man, with both dense and more open forest; they merit protection (WCMC, 1991).

Niega de la Embouchure

Diverse fauna exists in this area (WCMC, 1991).

\section{Tanoé Forest}

Intact swamp forests occur here (WCMC, 1991). 
Ecologically Sensitive Sites of Africa

COTE D'IVOIRE - PROTECTED SITES

National/international designations

Name of area and

map reference (see Fig. 5.1)

Management

Year

area (ha)

notified

\section{Classified Forests}

Abounderessou

3,200

Ahua

2,400

Akabo

2,300

Anguededou

840

Badenou

28,300

Badikaha

13,300

Bafing

2,200

Bamo

250

Bamoro

2,200

Bandama Supérieur

45,000

Bandama-Blanc

50,500

Baya-Korore

12,200

Belefima

22,800

Besse-Boka

7,600

Besso

23,100

Biki-Bossematie

38,900

Boka-Go

4,900

Bolo

8,800

Borotou

10,400

Bouafle

20,350

Brassue

20,000

Comoé

1,600

Davo

12,580

Dents de Man

136

Diambarakrou

27,350

Divo

7,350

Dogodou

22,400

Doka

14,400

Doubele

4,300

Duékoué

47,600

Dyengele

2,600

Fetekro

Flan Soblysiemen

4,800

Go-Bodienou

16,700

60,000

Goin-Cavally

189,000

Gorke

4,100

Goudi

9,600 


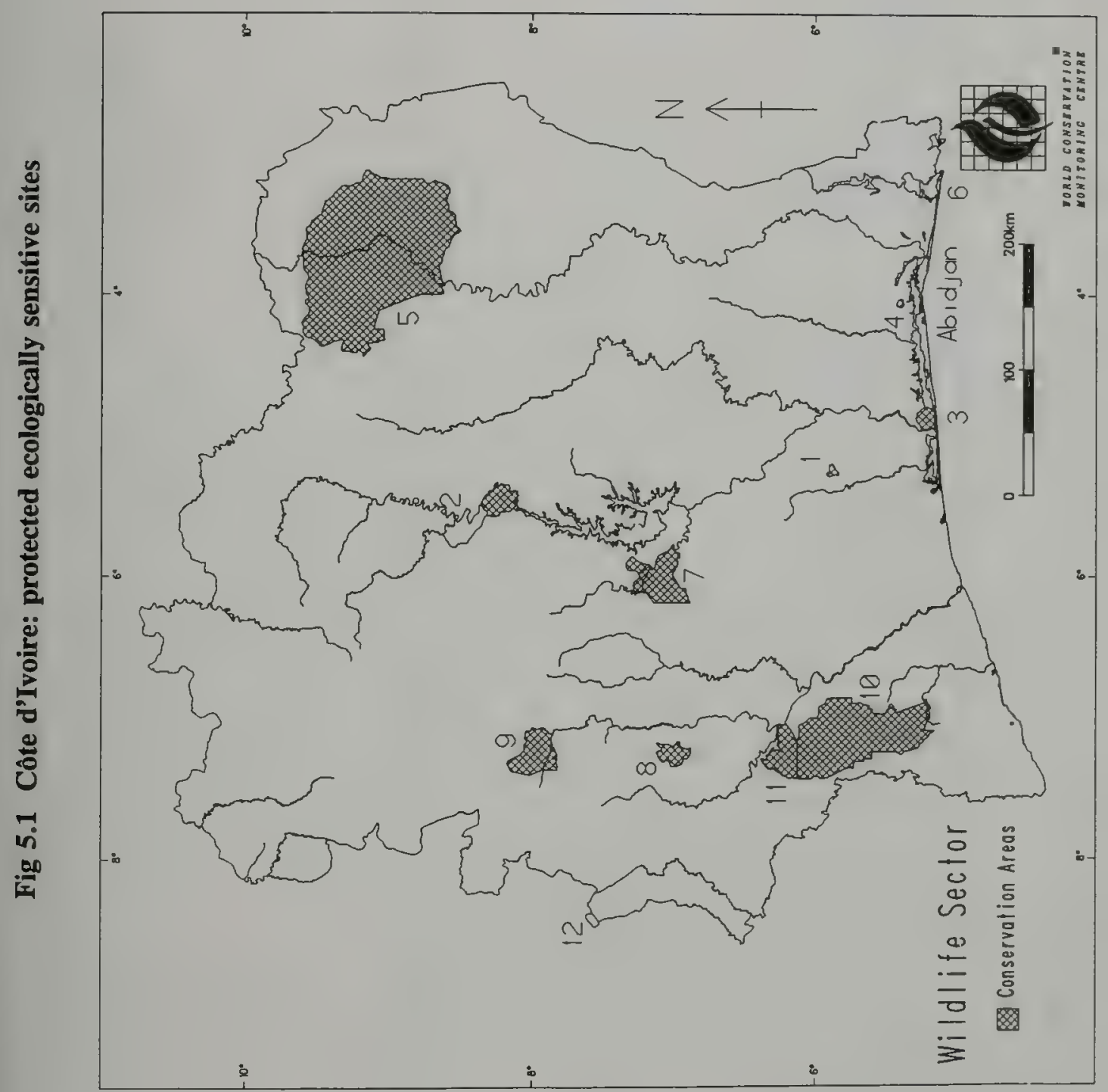


Ecologically Sensitive Sites of Africa

COTE D'IVOIRE - PROTECTED SITES (cont.)

National/international designations

Name of area and

map reference (see Fig. 5.1)

$\begin{array}{ll}\begin{array}{c}\text { Management } \\ \text { area (ha) }\end{array} & \begin{array}{l}\text { Year } \\ \text { notified }\end{array}\end{array}$

Gouele

11,600

Goulaleu

950

Guinteguela

9,600

Hana

72,000

Haut Dodo

109,400

Haut-Bandama

84,000

Haut-Sassandra

102,400

Hein N'Zodji

23,400

Ira

13,000

Irobo

24,500

Kanhasso

Kani-Bandama Rouge

5,900

Kanoumou

105,000

Kassa

4,000

7,000

Kere

1,200

Keregbo

21,300

Kimbrila

1,100

Kinkene

45,300

Kiohan

1,500

Koba (Nord)

2,600

Koba

31,430

Kobo

Kogaha

14,200

Korhogo

15,900

1,600

Korondekro

700

Kouaba-Boka

3,200

Kouin

5,000

Koumo-Kafaka

9,000

Kouroukouna

3,200

Kroziale

9,300

3,960

Lahouda

5,800

Leraba

23,500

Logahan

2,500

Loho

92,100

Lokpoho

3,400

Loviguie

2,800

Maby

63,100

Mafa

13,400

Mando

11,300 
COTE D'IVOIRE - PROTECTED SITES (cont.)

National/international designations

Name of area and

map reference (see Fig. 5.1)

$\begin{array}{ll}\begin{array}{l}\text { Management } \\ \text { area (ha) }\end{array} & \begin{array}{l}\text { Year } \\ \text { notified }\end{array}\end{array}$

Manzan

Matiemba

Miniabo

Monoga

Mont $\mathrm{Ba}$

Mont Bableu

Mont Gbande

Mont Glo

Mont Ko

notified

Mont Kourabah

Mont Kouzan-Kourou

4,500

960

600

35,000

4,500

15,400

23,100

14,000

49,000

3,350

1,800

Mont Sangbe

Mont Tonkoui

37,400

4,200

2,850

8,000

Mont-Momi

11,300

Mont-Nieton

Mont-Nimba

Mont-Tia

19,500

Mopri

16,300

N'Ganda-N'Ganda

33,000

2,400

N'Golodougou

4,000

N'Guechie

N'to

2,800

15,800

Nambon Kaha

3,200

Nanyelongo

600

Niangbon

Niegre

Niouniourou

1,700

100,800

19,670

Nougbo

20,800

Nyangboue

Nyellepuo-N'Zi Supérieur

24,400

150,400

Okromodou

94,500

Palee

Poro-Poro

50,500

Poue-N'Zue

800

1,500

Poulla

Poumbou

60,000

Prikro-Baya

4,600

7,000

Proungboserebi

52,800 
Ecologically Sensitive Sites of Africa

\section{COTE D'IVOIRE - PROTECTED SITES (cont.)}

National/international designations

Name of area and

map reference (see Fig. 5.1)

$\begin{array}{ll}\text { Management } & \text { Year } \\ \text { area (ha) } & \text { notified }\end{array}$

Rapidegrah
Rasso
Raviart
Samankono
Sanaimbo
Sananferedougou
Sangoué
Sangouine
Sanvan
Scio
Seguela
Seguie
Silue
Singrobo
Songan
Soungourou
Suitoro
Tafire
Tagba
Tamin
Tebe
Tene
Teonle
Tiapleu
Tieme
Tiengala
Tienny
Tindikro
Touro
Warigue
Yalo
Yapo
Yaya
Zuoke

204,200

2,700

800

3,900

5,200

470

36,280

32,000

3,600

133,800

6,300

19,600

40,400

1,200

31,000

5,200

22,600

8,300

3,200

46,300

5,000

29,400

4,000

26,700

890

2,700

13,800

500

580

62,100

26,200

35,000

29,400

9,000

Botanical Reserve

1 Divo 
COTE D'IVOIRE - PROTECTED SITES (cont.)

National/international designations

Name of area and

map reference (see Fig. 5.1)

Management Year area (ha) notified

Fauna and Flora Reserve

2 Haut Bandama

123,000

1973

\section{National Parks}

3 Azagny

19,000

1981

4 Banco

3,000

1953

5 Comoé

6 Iles Ehotile

$1,150,000$

1968

10,500

1974

7 Marahoue

101,000

1968

8 Mont Peko

34,000

1968

9 Mont Sangbe

95,000

1976

10 Taï

350,000

1973

\section{Partial Faunal Reserve}

11 N'Zo

95,000

1972

Strict Nature Reserve

12 Mont Nimba

Biosphere Reserves

Parc national de Taï

Parc national de la Comoé

\section{World Heritage Sites}

Comoé National Park

$1,150,000$

1983

Mont Nimba Strict Nature Reserve

5,000

1982

Taï National Park

330,000

1982 
Ecologically Sensitive Sites of Africa

\section{COTE D'IVOIRE - UNPROTECTED SITES}

Name of area and

map reference (see Fig. 5.2)

1 Aby Lagoon

Ayame Forest

2 Azuretti Mangroves

3 Bandama River Lagoons Basse Dodo

4 Canal d'Asagni Wetlands

5 Cape Palmas

Dagbégo Lagoon

6 Fresco Lagoons Mankono Region

7 Mont Kopé a Grabo

8 Monts du Toura

9 Niega de la Embouchure

10 Tanoé Forest
Management area (ha) 


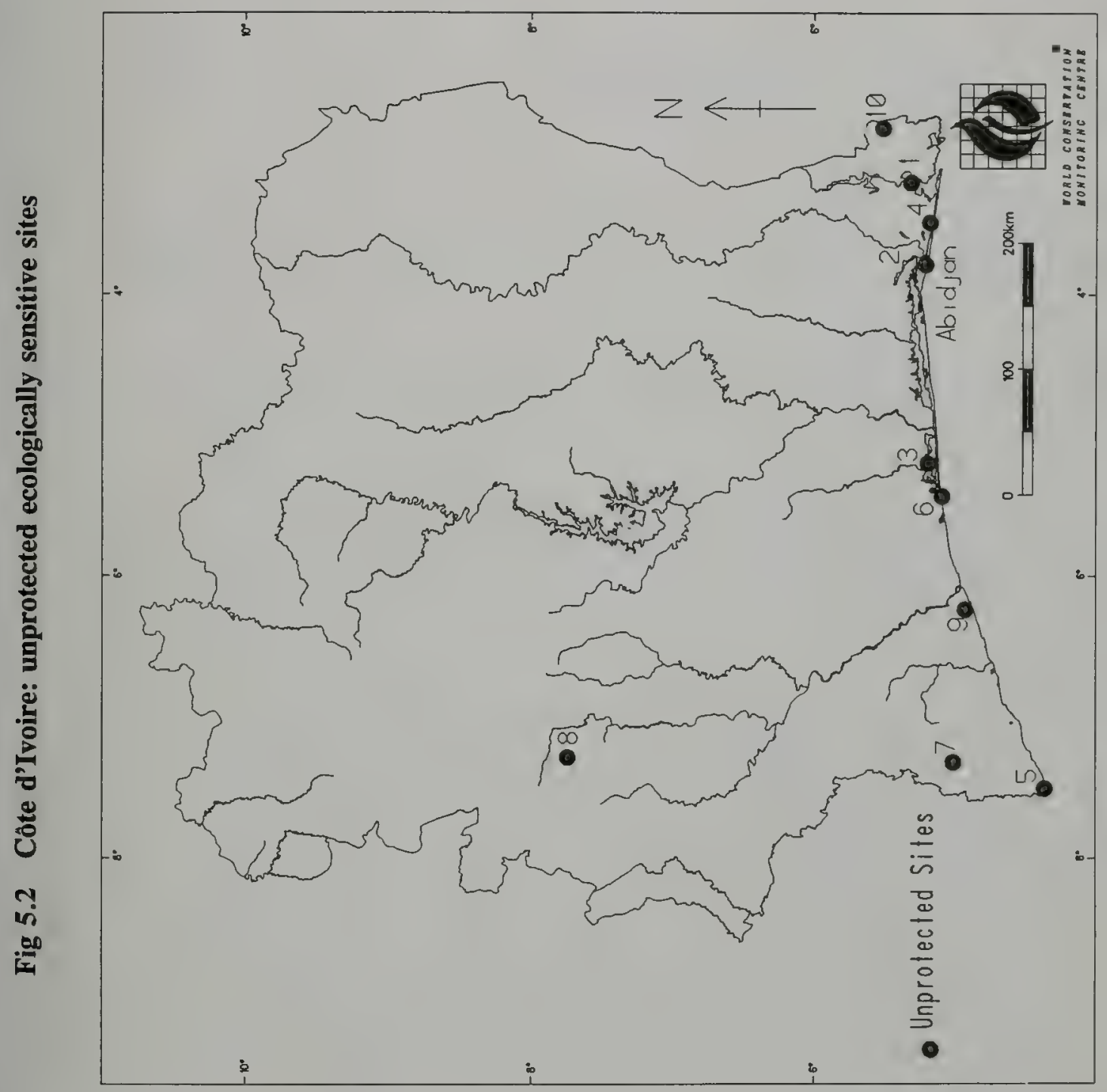





\section{EQUATORIAL GUINEA}

\section{INTERNATIONALLY DESIGNATED PROTECTED AREAS}

None

\section{NATIONALLY PROTECTED AREAS}

Altos de Nsok Protected Area

$1^{\circ} 20^{\prime} \mathrm{N}, 11^{\circ} 16^{\prime} \mathrm{E}$ Covering 40,000 ha in the Nsok Highlands, this proposed protected area contains pristine forest of importance to wildlife (IUCN/CNPPA, 1991; MALFF, 1991).

\section{Annobon - see Isla de Annobon Protected Area}

Bioko Island: Mt Malabo (Pico Santa Isabel) - see Pico Basile o Sta Isabel Protected Area

Estuario de Rio Muni Protected Area

$1^{\circ} 07^{\prime} \mathrm{N}, 9^{\circ} 47^{\prime} \mathrm{E}$ Covering $70,000 \mathrm{ha}$ of mangroves and riparian forest, this is the only known manatee habitat in the country (MALFF, 1991; Stuart et al., 1990).

Estuario de Rio Ntem (Campo) Protected Area

$2^{\circ} 07^{\prime} \mathrm{N}, 9^{\circ} 59^{\prime} \mathrm{E}$ (centre) This estuarine habitat covers $20,000 \mathrm{ha}$, and includes the Rio Mbia with its forest, mangroves and coastal areas. Birdlife, crocodile and hippopotamus occur (MALFF, 1991; Stuart et al., 1990).

\section{Gran Caldera de Luba - see Sur de la Isla de Bioko}

Isla de Annobon Protected Area

$1^{\circ} 25^{\prime} \mathrm{S}, 5^{\circ} 37^{\prime} \mathrm{E}$ This $7 \mathrm{~km}$ by $2.5 \mathrm{~km}$ island is the smallest and most remote of the Gulf of Guinea islands, located $180 \mathrm{~km}$ from Principe. About 1700 ha have been recommended as a conservation area, incorporating three volcanic peaks reaching an elevation of $655 \mathrm{~m}$ and including a shallow crater lake about $600 \mathrm{~m}$ in diameter. Because of the island's remoteness the avifauna is impoverished, consisting of two endemic species of resident passerines. It supports 17 other endemic species, and green and hawksbill turtles breed here. It is important for seabird and cetacean conservation. The human population has been relatively stable for several centuries, and the vegetation has consequently been modified far less than on São Tomé and Príncipe (Harrison, 1990; IUCN, 1987; MALFF, 1991; Stuart et al., 1990).

Macizo de Monte Alen Protected Area

$1^{\circ} 38^{\prime} \mathrm{N}, 10^{\circ} 16^{\prime} \mathrm{E}$ (centre) Covering an area of $80,000 \mathrm{ha}$, this area supports lowland gorilla, elephant and leopard (IUCN, 1987; MALFF, 1991; Stuart et al., 1990). 
Macizo de los Montes Mitra Protected Area

$1^{\circ} 24^{\prime} \mathrm{N}, 9^{\circ} 57^{\prime} \mathrm{E}$ Covering $30,000 \mathrm{ha}$ of rain forest up to $1200 \mathrm{~m}$ on the peaks of Atom, Mabumu-Wom, Behuo and Mitong, to the north-east of Estuario de Rio Muni. Elephant, buffalo, leopard and several primates occur (MALFF, 1991; Stuart et al., 1990).

Monte Alen - see Macizo de Monte Alen

\section{Pagalu Island see Isla de Annobon}

Pico Basile o Sta Isabel Protected Area

$3^{\circ} 35^{\prime} \mathrm{N}, 8^{\circ} 46^{\prime} \mathrm{E}$ Covering $35,000 \mathrm{ha}$ of montane and lowland forests between $640 \mathrm{~m}$ and $3008 \mathrm{~m}$, the area is home to an endemic bird, the Fernando Po speirops Speirops brunneus, which occurs in the highest lichen forest and heath zone; there are other, endemic bird subspecies. The forests are important for water and soil conservation, are unsuitable for agriculture, and have little timber of commercial value. There is reasonable tourism potential, and limited hunting occurs (Collar and Stuart, 1988; Frame, 1987; IUCN, 1987; MALFF, 1991).

\section{Rio Ntem-Rio Mbia - see Estuario de Rio Ntem Protected Area}

Sur de la Isla de Bioko Protected Area

$3^{\circ} 10^{\prime}-3^{\circ} 50^{\prime} \mathrm{N}, 8^{\circ} 25^{\prime}-9^{\circ} 00^{\prime} \mathrm{E}$ This area is on Bioko Island, the nearest of the Gulf of Guinea islands to the mainland. The proposed protected area covers about $60,000 \mathrm{ha}$ in area between sea-level and $2230 \mathrm{~m}$; it comprises a volcanic caldera adjacent to forests and the southern coast of the island. The unique montane forest shows strong affinities to the flora of Mount Cameroon on the mainland. Several endemic subspecies of primate occur, as do endemic subspecies of Ogilby's and blue duikers, the Bioko batis and several endemic reptiles and amphibians. The conservation proposals include offshore coastal waters; green and hawksbill turtles nest on the beaches (Frame, 1987; IUCN, 1987; Stuart et al., 1990; MALFF, 1991).

\section{OTHER MANAGED SITES}

None

\section{UNPROTECTED SITES}

\section{Mbini Forest}

This site supports lowland rain forest, with populations of red-capped mangabey, mandrill, black colobus, chimpanzee and gorilla. Buffalo and about 500 elephant occur. It is one of two known localities of the goliath frog Conrana goliath (Stuart et al., 1990). 
This degazetted park formerly covered 26,000 ha and supported chimpanzee, buffalo and gorilla; it is thought that it should be re-established (IUCN/UNEP, 1987; Stuart et al., 1990).

\section{Rio Ekuku Game Reserve}

This reserve covered 7500 ha and supported a good population of game, especially sitatunga. The protected area should be re-established (IUCN/UNEP, 1987; Stuart et al., 1990). 
EQUATORIAL GUINEA - PROTECTED SITES

National/international designations

Name of area and

map reference (see Fig. 6.1)

Management

area (ha)

40,000

70,000

20,000

1,700

80,000

30,000

15,000

60,000
Year

notified

1990

1990

1990

1990

1990

1990

1990

1990 


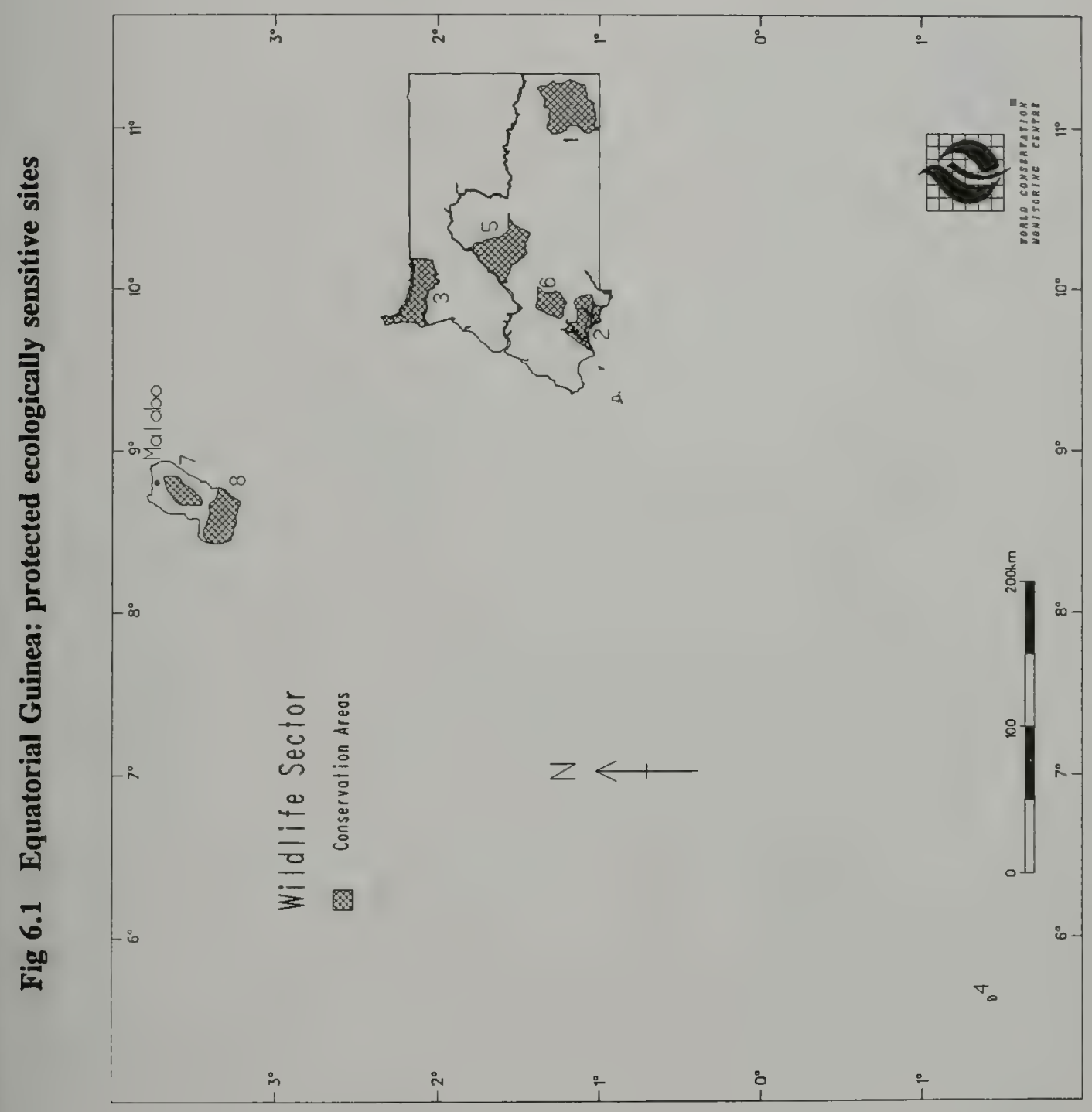


Ecologically Sensitive Sites of Africa

\section{EQUATORIAL GUINEA - UNPROTECTED SITES}

Name of area and

map reference (Fig 6.2)

1 Mbini Forest

Monte del Frio National Park

Monte Raices Nature Park

26,000

Rio Ekuku Game Reserve

7,500 
Equatorial Guinea

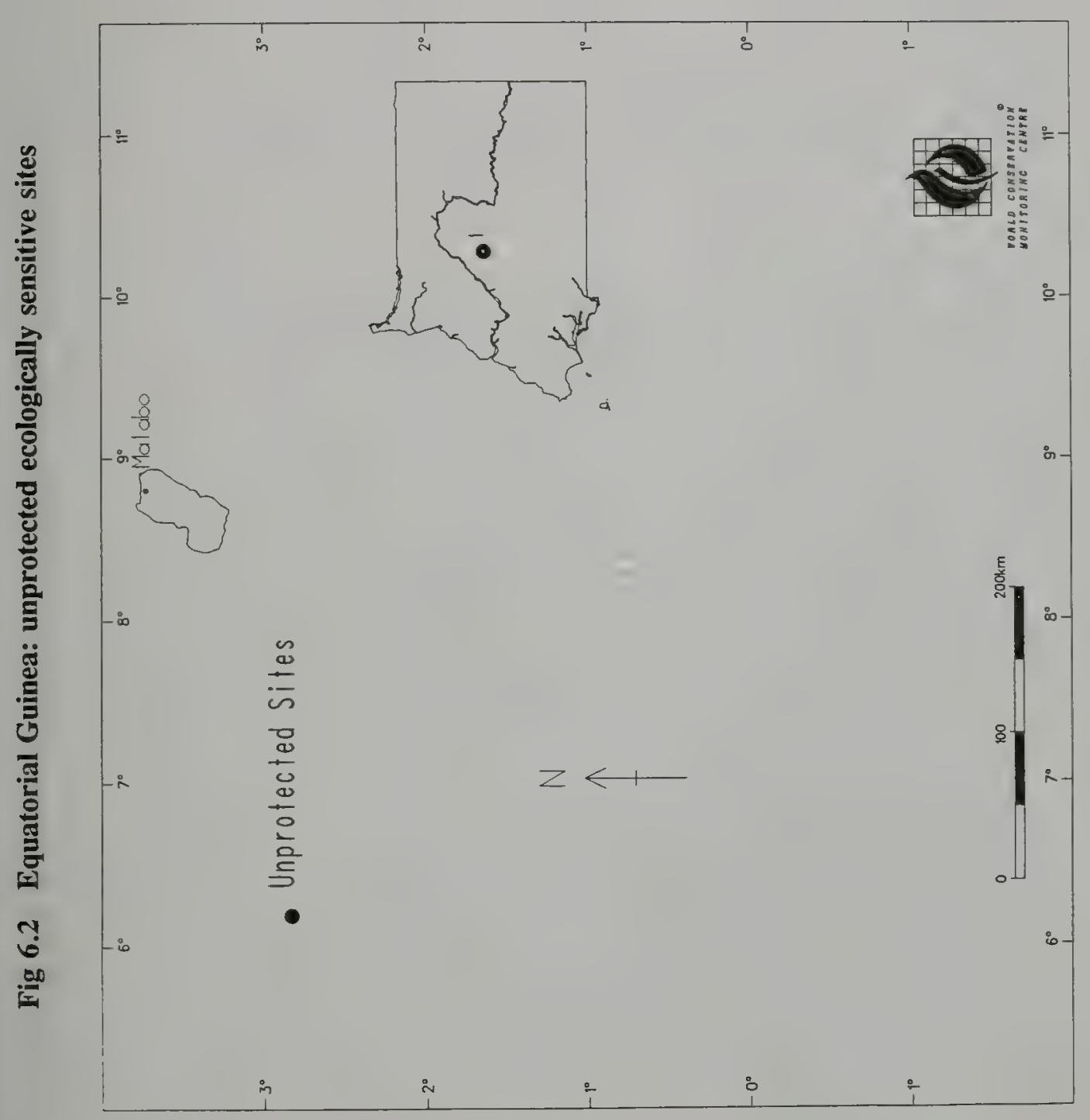





\section{GABON}

\section{INTERNATIONALLY DESIGNATED PROTECTED AREAS}

\section{Ipassa-Makokou Strict Nature Reserve}

IUCN Categories I and IX This flat reserve of $15,000 \mathrm{ha}$ has a core area of 10,000ha, and the Ivindo River as its southern boundary. Humid dense evergreen lowland rain forest of the Congo-Guinean type predominates. The vertebrate fauna is rich, with 130 mammal and over 400 bird species recorded, including the threatened mandrill. This reserve is reported to be the only protected area in Gabon where forest exploitation has not occurred. However, villages across the Ivindo are encroaching, and increased poaching is reported to have severely reduced the fauna. Apart from the river, only $2 \mathrm{~km}$ of boundary are marked and active management and law enforcement are inadequate (IUCN/UNEP, 1987; WCMC, 1988a).

\section{Sette-Cama Reserves}

IUCN Category VIII The complex covers 700,000 ha and is divided between two Ramsar sites: Petit Loango, comprising Iguela Hunting Reserve $(180,000 \mathrm{ha})$ and Ngoué-Ndogo Hunting Reserve $(250,000 \mathrm{ha})$; and Sette-Cama, comprising Sette-Cama Hunting Area (200,000ha) and Ouanga Plain Faunal Reserve (20,000ha). The gently undulating sandy coastal plain includes an extensive lagoon and several lakes. Open savanna with thickets occurs in the littoral zone, with rain forest covering most of rest of the reserve. Much of the forest was exploited over 20 years ago. The reserve is particularly important for the African manatee, Bate's dwarf antelope and leatherback turtle, and there are also large populations of elephant, buffalo and several other, threatened mammals. One town is located within the reserve, and there is little protection. There is also Illegal oil exploration which is causing a number of problems, including increased access. A few safaris are organised each year for tourists (IUCN/UNEP, 1987; WCMC, 1988a).

Wonga-Wongué Presidential Reserve

IUCN Category IV This coastal reserve of $380,000 \mathrm{ha}$, which encompasses Wonga Wongué Hunting Area $(25,000 \mathrm{ha})$ is generally flat and low-lying. The whole area is also designated a Ramsar site. Vegetation varies from humid tropical rain forest to stunted woodland savanna. The area supports a varied fauna, including many elephant, buffalo $(30,000)$, chimpanzee, the western race of gorilla, and white pelican. Some exotic mammals have been introduced, which may pose management problems. Visits are only by invitation of the president, and the only access is by light aircraft. Anti-poaching activities are carried out and reported to be very effective, although considerable poaching and some forest exploitation have occurred in the past. An extension to include some swamp forest has been suggested (IUCN/UNEP, 1987; WCMC, 1988a).

\section{NATIONALLY PROTECTED AREAS}

\section{Lopé Faunal Reserve}

IUCN Category IV

This reserve of $500,000 \mathrm{ha}$ includes a mountainous area and the Lopé-Okanda plain. About $80 \%$ of the reserve is covered by Congo rain forest, over half of which is 
undisturbed, with small pockets of swamp forest and secondary grassland or forest in the north. The area is valuable for being linked to a large tract of forest, and is a stronghold of forest buffalo and elephant. At least 12 primate species are found, including gorilla, chimpanzee and drill (rare in Gabon). There are 1500 subsistence farmers in nine villages within the reserve, and illegal forestry occurs in the north. The presence of protection staff at Lopé village has reduced poaching both here and along the Trans-Gabon railway. Illegal burning occurs in parts, and oil exploration poses a threat (IUCN/UNEP, 1987; WCMC, 1988a).

Moukalaba-Dougoua Faunal Reserve

IUCN Category IV This reserve of 80,000 ha comprises the eastern slopes of the hills behind the coastal plain. It supports a mosaic of secondary grassland, gallery forest and rain forest. However, forestry permits only expired in 1988 and very little undisturbed forest now remains. There are a number of antelope on the reserve, and primate species include the threatened gorilla and elephant. Anti-poaching activities do not exist; the area has been heavily hunted in the past, and is still under pressure from poaching. The western boundary is unclear. Forestry activities have changed forest structure, and severe damage has been caused on some steep slopes (IUCN/UNEP, 1987).

\section{Ouanga Plain Faunal Reserve - see Sette-Cama Reserves}

\section{Petit Loango Faunal Reserve - see Sette-Cama Reserves}

Sibang - Station Expérimentale forestière de Sibangue

IUCN Category IV $0^{\circ} 25^{\prime} \mathrm{N}, 9^{\circ} 29^{\prime} \mathrm{E}$ Legally gazetted as a classifed forest, this reserve comprises 16 ha of secondary forest. It is considered uniquely valuable from a scientific point of view (IUCN, 1990a).

\section{OTHER MANAGED AREAS}

Grand Bam-Bam Hunting Area

Established in 1971, this covers 20,000ha.

\section{Iguela Hunting Area - see Sette-Cama Reserves}

Moukalaba Hunting Area

Established in 1962; covers 20,000ha

Ngove-Ndogo Hunting Area

Established in 1962; covers 250,000ha

IUCN Category VIII

Sette-Cama Hunting Area - see Sette-Cama Reserves

Sette-Cama Wildlife Management Area - see Sette-Cama Reserves

Wonga Wongue Hunting Area - see Wonga-Wongue Presidential Reserve 


\section{UNPROTECTED SITES}

\section{Akanda Mangroves}

$0^{\circ} 35^{\prime}-0^{\circ} 40^{\prime} \mathrm{N}, 9^{\circ} 26^{\prime}-9^{\circ} 33^{\prime} \mathrm{E}$ Bounded by the Mamboumbe, Tsini and Ambochou rivers, and the bays of Corisco and Mondah, this 7500ha area is a network of mangrove-covered islands and tidal channels, with primary and secondary forest occurring on higher ground. The largest island, Moka, reaches an elevation of $65 \mathrm{~m}$. Nile monitor, dwarf crocodile, water mongoose, sitatunga, talapoin Miopithecus talapoin, putty-nosed guenon Cercopithecus nictitans, collared mangabey and hippopotamus occur. Over 140 species of bird have been recorded, including numerous waders, waterbirds and several rare species (IUCN, 1990a).

\section{Cape Esterias - see Mondah Reserve}

\section{Djoua Reserve}

$1^{\circ} 05^{\prime}-1^{\circ} 22^{\prime} \mathrm{N}, 13^{\circ} 18^{\prime}-14^{\circ} 00^{\prime} \mathrm{E}$ Situated south of the Djoua River on the Congolese border, this proposed reserve covers $160,000 \mathrm{ha}$ of swamp forest, primary forest, and open marshes and swamps. The area is biologically interesting. There are no permanent settlements, although it is used by hunters (IUCN, 1990a; Stuart et al., 1990).

Dolle Faunal Reserve - see Mont Fouari Faunal Reserve/N'dende Faunal Reserve $10,000 \mathrm{ha}$

Domaine de Chasse de N'dende - see Mont Fouari Faunal Reserve/N'dende Faunal Reserve

\section{Elobey Islands}

$1^{\circ} 00^{\prime} \mathrm{N}, 9^{\circ} 31^{\prime} \mathrm{E}$ These islands are of importance because of their coral reefs (IUCN/CNPPA, 1991)

Forêt des Abeilles

$0^{\circ} 20^{\prime}-1^{\circ} 00^{\prime} \mathrm{S}, 11^{\circ} 45^{\prime}-12^{\circ} 10^{\prime} \mathrm{E}$ Situated against the south-eastern boundary of Lopé Faunal Reserve just to the north of Mont Iboundji in the extreme west of the Franceville Basin, this area covers $250,000 \mathrm{ha}$ of Guinea-Congolian forest between $200 \mathrm{~m}$ and $700 \mathrm{~m}$. It is the home of the recently-described sun-tailed monkey Cercopithecus solatus, and is of significance for birdlife (Collar and Stuart, 1988; IUCN, 1990a).

Franceville Forests - see Leconi

Gamba Reserve - see Monts Doudou

Grottes de Belinga - see Monts de Belinga and Grottes de Belinga 430ha 


\section{Lac Onangué - see Ogooué-Onangué Lake National Park}

\section{Leconi}

$1^{\circ} 35^{\prime}-2^{\circ} 03^{\prime} \mathrm{S}, 13^{\circ} 52^{\prime}-14^{\circ} 22^{\prime} \mathrm{E}$ Situated close to the Congolese border, this proposed protected area covers about $110,000 \mathrm{ha}$, and includes part of the Bateké Plateau; elevations range between $350 \mathrm{~m}$ and $830 \mathrm{~m}$. The vegetation is primarily savanna and gallery forest, and mammals include lion (the last in Gabon) African wild dog and side-striped jackal. The avifauna contains some locally rare species such as Denham's and black-bellied bustard, coqui and francolins Francolinus afer and $F$. finschi. Commercially exploited mineral springs exist, and the area has potential for tourism (IUCN, 1990a; Stuart et al., 1990).

\section{Milondo - see Mont Soungou and Mont Milondo}

Mingouli

Recommended $0^{\circ} 01^{\prime}-0^{\circ} 28^{\prime} \mathrm{N}, 12^{\circ} 22^{\prime}-12^{\circ} 58^{\prime} \mathrm{E}$ This area covers an area of 170,000 ha of GuineaCongolian forest and some swamp forest. Mammals include elephant, duiker, De Brazza's monkey, talapoin and chevrotain. There is no resident human population, and the area is recommended for protection (IUCN, 1990a; Stuart et al., 1990).

Minkebe Forests

Recommended $0^{\circ} 50^{\prime}-2^{\circ} 00^{\prime} \mathrm{N}, 12^{\circ} 10^{\prime}-13^{\circ} 00^{\prime} \mathrm{E}$ Covering an area of 700,000 ha of plateaus and valleys, these are primary forests of Guinea-Congolian affinities and are one of the biologically richest areas in Gabon. There is a high density of elephant, and 16 species of primate include gorilla, chimpanzee, Cercocebus agilis and De Brazza's monkey. Bongo, chevrotain and giant forest hog also occur, as does the endemic Gabon batis. The forests are lacking commercially viable stands of timber, and since costs of extraction are high, they are as yet unlogged. The human population is low, less than one person $/ \mathrm{km}^{2}$, and there is great conservation potential (Frame, 1987; IUCN, 1987 and 1990a; WCMC, 1988a).

Mondah Reserve

Proposed $0^{\circ} 34^{\prime} \mathrm{N}, 9^{\circ} 20^{\prime} \mathrm{E}$ Situated on the Atlantic shore and covered in Guinea-Congolian forests (primary and secondary) and low littoral scrub (Manilkara lacera), this reserve is botanically very rich and supports some local endemic forms. It includes Cape Esterias, of importance for its coral reefs. Because of its proximity $(25 \mathrm{~km})$ to Libreville it has been over-hunted and few larger mammals remain, although blue duiker have been reported. The area has great potential as a site for scientific study and education, and there is no resident human population (IUCN, 1990a).

\section{Dolle/Mont Fouari/N'dende Faunal Reserves}

This complex covers 62,000 ha, with a hunting area making up about $80 \%$ of the total. All three areas have now been degazetted. Predominantly bushy savanna with wooded mountains in the west, they support populations of waterbuck, sitatunga, buffalo, elephant, red-fronted gazelle, giant forest hog and a number of forest monkeys (IUCN/UNEP, 1987). 
Mont Fouari Faunal Reserve -see Dolle/Mont Fouari/N'dende Faunal Reserves

Mont Iboundji

Proposed

$1^{\circ} 00^{\prime}-1^{\circ} 13^{\prime} \mathrm{S}, 11^{\circ} 44^{\prime}-11^{\circ} 53^{\prime} \mathrm{E}$ Situated to the immediate south of the Forêt des Abeilles and Lopé Faunal Reserve, this area of Guinea-Congolian forest covers 25,000 ha between $250 \mathrm{~m}$ and $972 \mathrm{~m}$. The southern part of the area is dominated by Mont Iboundji, the higher parts of which are covered in a rich and interesting primary forest. It is proposed as a protected area, primarily for botanical reasons (IUCN, 1990a; Stuart et al., 1990).

Monts de Belinga and Grottes de Belinga

$0^{\circ} 55^{\prime}-1^{\circ} 18^{\prime} \mathrm{N}, 13^{\circ} 08^{\prime}-13^{\circ} 15^{\prime} \mathrm{E}$ This is an area of $200-300 \mathrm{ha}$, attaining a maximum elevation of $1024 \mathrm{~m}$. The vegetation is a botanically unique dwarf thicket consisting of about 18 species, including species of Cassipourea, Garcinia, Homalium, Hymenocardia and Ocotea. The Grottes de Belinga are situated at $1^{\circ} 04^{\prime} \mathrm{N}, 13^{\circ} 02^{\prime} \mathrm{E}$, and support large (over 500,000) numbers of bats and the threatened bare-necked rockfowl (IUCN, 1990a).

\section{Monts Doudou}

$1^{\circ} 50^{\prime}-2^{\circ} 55^{\prime} \mathrm{S}, 10^{\circ} 10^{\prime}-10^{\circ} 30^{\prime} \mathrm{E}$ Sandwiched between the protected areas of SetteCama, this area is considered worthy of protection.

\section{Monts du Chaillu - see Mont Soungou and Mont Milondo}

\section{Mont Soungou and Mont Milondo}

$1^{\circ} 26^{\prime}-1^{\circ} 48^{\prime} \mathrm{S}, 11^{\circ} 40^{\prime}-12^{\circ} 06^{\prime} \mathrm{E}$ Covering an area of 100,000 ha on the Monts du Chaillu massif between $500 \mathrm{~m}$ and $1022 \mathrm{~m}$, this is one of the higher parts of Gabon. It is characterised by the large number of river courses, which have formed many rapids and waterfalls. The main vegetation types are Guinea-Congolian lowland, secondary and wet sub-montane forest, with a high level of floristic endemism. The mammalian fauna has been over-hunted, but several rare birds occur; the threatened Dja River warbler Bractypterus grandis is known primarily from the non-forest areas, and the forests support Picathartes oreas, black river duck Anas sparsa and Hirundo fuliginosa. Protection for the region is recommended (IUCN, 1990a; Stuart et al., 1990).

\section{N'dende Faunal Reserve -see Dolle/Mont Fouari/N'dende Faunal Reserves}

\section{Ogooué-Onangué Lake National Park}

$0^{\circ} 45^{\prime}-1^{\circ} 15^{\prime} \mathrm{S}, 9^{\circ} 45^{\prime}-10^{\circ} 25^{\prime} \mathrm{E}$ Covering about $200,000 \mathrm{ha}$, this area includes Lakes Onangué, Ezanga, Evaro, Nvondjé and Oguémoué, and a section of the Ogooué River. The vegetation is dominated by primary and secondary rain forest, and swamp forest. The area is little-known botanically, but includes 14,000 ha of tidal forest, Pandanus and palm swamp. Manatee, hippopotamus, dwarf and long-snouted crocodile, elephant, buffalo, sitatunga, chevrotain, bushbuck, bushpig, Cephalophus sylvicultor, gorilla and chimpanzee are known to occur. Birdlife is very rich, and 
includes several rare species. The area is home to a wealth of waterbirds, many of which breed here. The National Park will be formed by the amalgamation of the Lopé and Okanda reserves and adjacent areas. The human population is fairly high, and the area is strongly recommended as a national park (IUCN, 1990a; Stuart et al., 1990; WCMC, 1988a).

\section{Ozouri}

$1^{\circ} 02^{\prime}-1^{\circ} 22^{\prime} \mathrm{S}, 8^{\circ} 53^{\prime}-9^{\circ} 08^{\prime} \mathrm{E}$ Covering $44,000 \mathrm{ha}$ on the Atlantic shore between the Ozouri River and Nkomi Lagoon, this area reaches an altitude of $23 \mathrm{~m}$. It includes Olendé Lagoon, Ikandou drainage and the Inguessi Plains. Vegetation includes mangroves, littoral scrub, primary and secondary forest, and savanna. Elephant, buffalo, hippopotamus, sitatunga, collared mangabey and talapoin are found. The area supports a wealth of avifauna, particularly waterfowl, and leatherback turtle breed on the shore. The area is recommended as a national park (IUCN, 1990a).

\section{Soungou - see Mont Soungou and Mont Milondo}

\section{Tchimbélé (Mont Cristal)}

$0^{\circ} 10^{\prime}-1^{\circ} 00^{\prime} \mathrm{N}, 10^{\circ} 13^{\prime}-10^{\circ} 58^{\prime} \mathrm{E}$ Situated immediately south of the border with Equatorial Guinea north of the town of Kango, this area covers 410,000 ha of GuineaCongolian forest and secondary forest, as well as inselbergs and their associated flora. It incorporates the Kinguélé and Tchimbélé hydro-electric schemes, and the man-made Lake Tchimbélé. The forest on Mont Cristal is biologically rich and contains an exceptional number of endemic forms, including six endemic species of Begonia. Elephant, gorilla and chimpanzee are known to occur. Residents of the Libreville area hunt in the region, and the area is strongly recommended for protection (IUCN, 1990a; Stuart et al., 1990). 


\section{GABON - PROTECTED SITES}

National/international designations

Name of area and

map reference (see Fig. 7.1)

Management

area (ha)

16

1934

Sibang

Faunal Reserves

1 Lope

2 Moukalaba-Dougoua

3 Ouanga Plain

4 Petit Loango

Hunting Areas

5 Grand Bam-Bam

6 Iguela

7 Moukalaba

8 Ngoué-Ndogo

9 Sette-Cama

10 Wonga Wongué

Presidential Reserve

11 Wonga-Wongué

Strict Nature Reserve

12 Ipassa-Makokou
500,000

1962

80,000

20,000

1962

50,000

1966

1966

20,000
180,000
20,000
250,000
200,000
25,000

1971

1962

1962

1962

1962

1962

380,000

1971

15,000

1970

Sites 5 and 10 lie within Site 11 . They are not mapped as information concerning their exact location was not available.

Biosphere Reserves

Réserve naturelle integrale

d'Ipassa-Makokou

15,000

1983

Ramsar Sites

Petit Loango

Setté Cama

Wonga-Wongué 
Ecologically Sensitive Sites of Africa

Fig 7.1 Gabon: protected ecologically sensitive sites

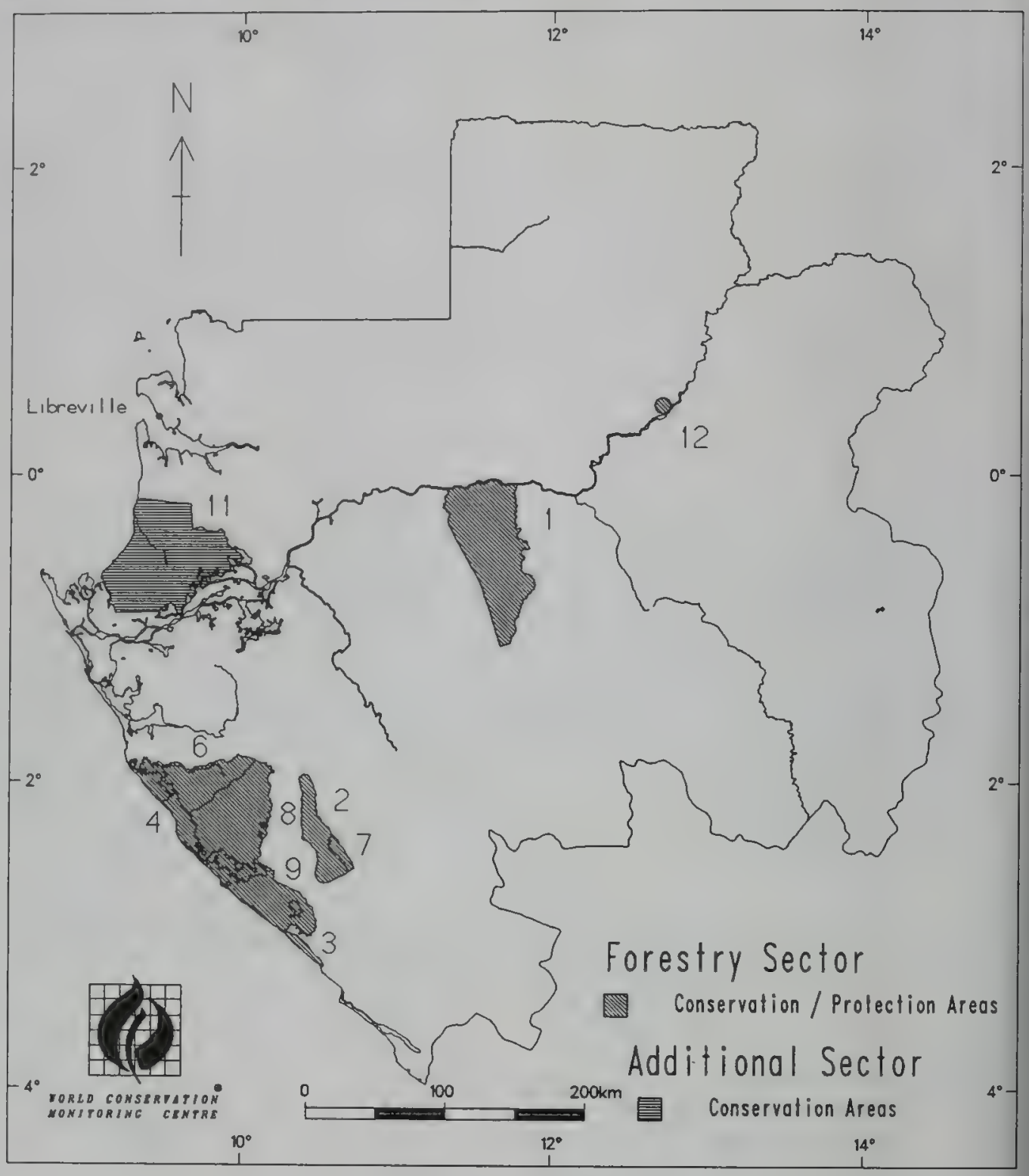




\section{GABON - UNPROTECTED SITES}

Name of area and

map reference (see Fig. 7.2)

Management

area (ha)

1 Akanda Mangroves

7,500

2 Djoua Reserve

160,000

Dolle Faunal Reserve

3 Elobey Islands

Forêt des Abeilles

250,000

4 Leconi

110,000

5 Mingouli

170,000

6 Minkebe Forests

7 Mondah Reserve

700,000

Mont Fouari Faunal Reserve

740

8 Mont Iboundji

9 Monts de Belinga and Grottes de Belinga

25,000

10 Monts Doudou

260,000

100,000

N'dende Faunal Reserve

12 Ogooué-Onangué Lake National Park

200,000

13 Ozouri

44,000

14 Tchimbélé (Mont Cristal)

410,000 
Ecologically Sensitive Sites of Africa

Fig 7.2 Gabon: unprotected ecologically sensitive sites

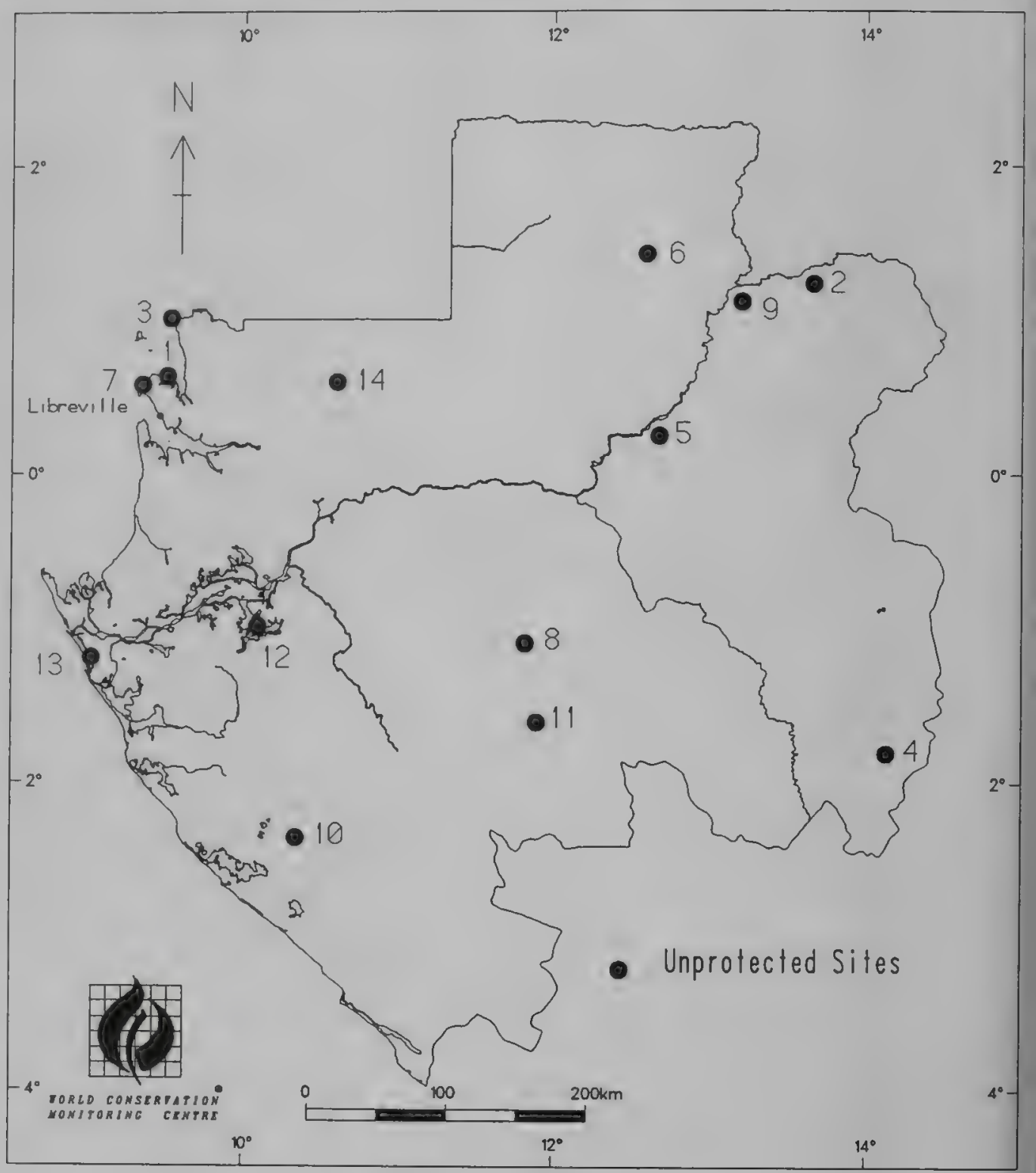




\section{GUINEA}

\section{INTERNATIONALLY DESIGNATED PROTECTED AREAS}

\section{Ile Alcatraz}

$10^{\circ} 38^{\prime} \mathrm{N}, 15^{\circ} 23^{\prime} \mathrm{W}$ The rocky islet of Alcatraz is $40 \mathrm{~km}$ off shore from the border with Guinea-Bissau and covers about 0.75ha. Established as a Ramsar Wetland Site of 1 ha in 1992. It was first protected in 1932, but no effective control has been in force. It rises abruptly from the sea, reaching a maximum height of $12 \mathrm{~m}$ above sea-level. The fairly flat surface is covered with up to $3 \mathrm{~m}$ of guano, and is unvegetated. The island is important as one of the few breeding sites in West Africa for the Atlantic race of brown booby Sula leucogaster, and the nests of about 3000 pairs of these birds cover the plateau. Because of its barrenness, very few other bird species visit the island. In the 1930s, people used to visit the island during the dry season in order to collect guano, but it is no longer inhabited. Access is difficult, and the local fishermen avoid the island because of dangerous currents, and because the accumulated guano is offensive. The sandy Ile de Naufrage, a few kilometres away, also has important nesting colonies (Altenburg, 1987; IUCN, 1987; WIWO, 1989).

\section{Iles Tristao}

$10^{\circ} 53^{\prime} \mathrm{N}, 15^{\circ} 03^{\prime} \mathrm{W}$ The Tristao Islands, cover a total area of about 50,000 ha and form the most north-eastern part of Guinea, at the mouth of the Rio Komponi. Iles Tristao Ramsar Wetland Site $(85,000 \mathrm{ha})$ was established in 1992. Mangroves are dominant, deeply penetrated by creeks, and much of the area floods at high tide. There are dunes up to $5 \mathrm{~m}$ high on the inland part, which support a total of about $250 \mathrm{ha}$ of degraded forest fragments and savanna. At low tide about $2300 \mathrm{ha}$ of mudflats are exposed. Not far off the western side of the largest island, Katarak, is a sandy islet called Pani Bankhi, which supports large breeding populations of African spoonbill, sacred ibis and Caspian tern. Pink-backed pelican and crowned crane nest on the islands, and other, non-resident species, occur. There are a few dozen villages on the islands; the inhabitants grow crops and consume waterfowl (Altenburg, 1987; IUCN, 1987; WIWO, 1989).

\section{Konkoure}

Established as a 90,000ha Ramsar Wetland Site in 1992.

\section{Massif du Ziama Strict Nature Reserve}

IUCN Categories I and IX This reserve comprises 116,170 ha of mountainous landscape characterised by rugged relief, with a core area of $60,000 \mathrm{ha}$. It includes the largest area of natural forest in Guinea, as well as degraded forest and savanna on lateritic outcrops, and swamps. Parts have been cultivated, and about $80,000-90,000$ ha of forest remain. The area is reported to support elephant, and various species of antelope and monkey. Timber extraction is permitted on a concession of $30,000 \mathrm{ha}$ in the buffer zone, and there is also a forestry station, chipboard factory, quinine plantation, processing station and an 8 ha palm grove. A human population of 29,000 lives in 23 villages and one town, within the reserve. The reserve needs to be gazetted, and its boundaries should include the Fouta Djallon Plateau. It is the location of a World Bank Forest Management 
Project. Some forests below $510 \mathrm{~m}$ altitude will be inundated by the Diami dam (IUCN/UNEP, 1987).

Mount Nimba Strict Nature Reserve

IUCN Categories I, IX and X

Mount Nimba is subdivided between three countries. Guinea preserves $13,000 \mathrm{ha}$ of the mountain as a strict nature reserve, which comprises most of Guinea's section of the 17,130 ha biosphere reserve (some sources give the nature reserve's area as 17,500ha). The Guinea sector, together with 5000ha in Côte d'Ivoire, also forms a World Heritage Site, contiguous to a proposed nature reserve in Liberia. This area includes the third highest mountain $(1752 \mathrm{~m})$ in West Africa west of the Cameroon chain. There is a continuum of habitats, from savanna on infertile, iron-rich soils at an elevation of about $500 \mathrm{~m}$, through low-lying moist rain forest and dry mid-altitude forest, to high altitude grassland on the summits. The area has been identified as a centre of plant diversity under the IUCN-WWF Plants Conservation Programme. Several threatened species of fauna are to be found, including pygmy hippopotamus Choeropsis liberiensis, leopard and chimpanzee. The Liberian section of the reserve is still not protected; poaching occurs, and massive iron ore mining operations are in progress (the whole mountain is rich in iron ore). Only the Guinea and Côte d'Ivoire sectors are included in the World Heritage Site, while the Biosphere reserve is restricted to Guinea. In parts of the strict nature reserve in the Guinea sector, there are areas where mining and settlement occurred in the past. The renewal of iron ore exploitation in the central part of Guinean Mount Nimba was planned for 1990, over an area of $197 \mathrm{ha}$ at about 300m altitude (IUCN/UNEP, 1987; Wilson in litt., 1991).

\section{Rio Kapatchez}

Established as a 20,000ha Ramsar Wetland Site in 1992.

\section{Rio Pongo}

Established as a 30,000ha Ramsar Wetland Site in 1992.

\section{NATIONALLY PROTECTED AREAS}

\section{Badiar National Park}

IUCN Category II Also known as Tomine, this park covers 38,200 ha in the Koundara prefecture. Although gazetted in 1985, management was not being implemented by 1987; an area of 13,000 ha was originally gazetted as Badiar-nord Forest Reserve. The park is situated in the north-west of the country in the transition zone between lowland forest and savanna, and is contiguous to Niokolo Koba National Park in Senegal. It was set up partly to deter Guinean grazers and poachers from entering the Senegal park. The park comprises a mosaic of dry forest and wooded savanna, and it is rumoured that, although large wildlife is scarce here, it is more prolific further east in Guinea. The EC has funded initial faunal surveys (Wilson in litt., 1991). 


\section{OTHER MANAGED SITES}

Beyla Prefecture Périmètre de Reboisement Classified Forest

Established in 1956; 381 ha

IUCN Category VIII

\section{Badiar-nord - see Badiar National Park}

Badiar-sud Classified Forest

IUCN Category VIII

Situated in Koundara prefecture and originally gazetted as a Forest reserve in 1956, this forest covers $7300 \mathrm{ha}$. It includes a mosaic of dry forest and wooded savanna, but it is rumoured that large wildlife is not abundant. Agricultural incursion is a serious threat (IUCN/UNEP, 1987; Wilson in litt., 1991).

Bagata Classified Forest

IUCN Category VIII

Established in 1942; 2000ha

Bakoum Classified Forest

IUCN Category VIII

Established in 1951; 28,000ha

Balayan-Souroumba Classified Forest

IUCN Category VIII This classified forest is situated in Dabola prefecture, and originally established as a forest reserve of $25,000 \mathrm{ha}$ in 1951 . It is the suggested location for trials on the management of natural Isoberlinia forest, using an early burning programme (Wilson in litt., 1991).

Bambaya Classified Forest

IUCN Category VIII Situated in Kissidougou prefecture, this 336ha area was established in 1951.

Bani Classified Forest

IUCN Category VIII

Established in 1952; 18,900ha

\section{Banie Classified Forest}

Established in 1956; 23,160

IUCN Category VIII

Bantaravel Classified Forest

IUCN Category VIII

Situated in Mamou prefecture, this $675 \mathrm{ha}$ area was originally established as a Forest Reserve in 1936. The forests in this area are found between elevations of $600-1,000 \mathrm{~m}$, along with relics of the Fouta Djallon Parinari forest. All have been degraded to some extent, and rarely have a closed canopy; however, this forest is one of the betterconserved areas (Wilson in litt., 1991).

Baro Classified Forest

IUCN Category VIII In Kouroussa prefecture; an area of 8000 ha was originally established as a forest reserve in 1943. It includes dense dry forest (Wilson in litt., 1991). 
Beauvois Classified Forest

IUCN Category VIII

Established in 1945; 2300ha

Beko Classified Forest

IUCN Category VIII

Established in 1943; 800ha

Bellel Classified Forest

Established in 1944; 1350ha

IUCN Category VIII

Bero Classified Forest

Established in 1952; 23,600ha

IUCN Category VIII

Binti Classified Forest

In Pita prefecture, established in 1944; 410 ha

IUCN Category VIII

Botokoly Classified Forest

Established in 1942; 2300ha

IUCN Category VIII

Boula Classified Forest

Established in 1955; 27,500ha

IUCN Category VIII

Chutes de Kinkon Classified Forest

Established in 1955; 320ha

IUCN Category VIII

Chutes de Tinkisso Classified Forest

Established in 1944; 1100ha

IUCN Category VIII

Colline-Macenta Classified Forest

Established in 1945; 780ha

IUCN Category VIII

Counsignaki Classified Forest

Established in 1955; 13,700ha

IUCN Category VIII

Damakhania Classified Forest

Established in 1944; 425ha

IUCN Category VIII

Dara-Labe Classified Forest

IUCN Category VIII

Originally established in 1943 in Labe prefecture as a forest reserve, this area covers $375 \mathrm{ha}$. Much of it is degraded, but there are small areas of relict open Fouta Djallon forest (Wilson in litt., 1991).

Darawondi Classified Forest

Established in 1978; 30ha

IUCN Category VIII

Darou-Salam Classified Forest

Established in 1954; 17,474ha

IUCN Category VIII 
Diecke Classified Forest

IUCN Category VIII

Situated in Yomou prefecture, this area of 64,000 ha was originally established as a forest reserve in 1945. Dense, moist evergreen forest predominates, and it is the second-largest forest area in Guinea. Some parts of the original reserve have been lost to cultivation, leaving $52,000-54,000$ ha of high forest. It is the location of a World Bank Forest Management Project. Formal protection has been proposed and a draft proposal drawn up (Wilson in litt., 1991).

Diego Tamba Classified Forest

IUCN Category VIII

Established in 1946; 70ha

Diogoure Classified Forest

IUCN Category VIII

In Mamou prefecture, established in 1943; 1000ha

Dixinn Classified Forest

IUCN Category VIII

In Dubrecka prefecture, established in 1944; 3900 ha

Djimbera (Bantiguel) Classified Forest

IUCN Category VIII

Established in 1983; 700ha

Dokoro Classified Forest

IUCN Category VIII

Established in 1952; 7800ha

Fanafanako Classified Forest

IUCN Category VIII

In Siguiri prefecture, established in 1986; 380ha

Fello Digui Classified Forest

IUCN Category VIII

Established in 1967; 2925ha

Fello Diouma Classified Forest

IUCN Category VIII Originally established as a forest reserve of $418 \mathrm{ha}$ in Mamou prefecture in 1936, this forested area lies between elevations of $600-1000 \mathrm{~m}$, with relics of the Fouta Djallon Parinari forest. All are degraded to an extent, and rarely have a closed canopy. However, this forest is one of the better conserved areas (Wilson in litt., 1991).

Fello Sounga Classified Forest

Established in 1953; 6700ha

IUCN Category VIII

Fello-Selouma Classified Forest

IUCN Category VIII

Established in 1955; 4000ha

Fello-Touni Classified Forest

IUCN Category VIII

Established in 1983; 100ha

Fitacouna Classified Forest

In Mamou prefecture, established in 1942; 95ha 
Fougoumba Classified Forest

IUCN Category VIII

Established in 1944; 795 ha

Foye-Madinadian Classified Forest

IUCN Category VIII

Established in 1954; 1595ha

Galy Classified Forest

IUCN Category VIII

Established in 1943; 1500ha

Gambi Classified Forest

IUCN Category VIII

Established in 1955; 15,500ha

Gangan Classified Forest

IUCN Category VIII

This forest reserve in Forecariah prefecture covers 9000 ha. Originally established in 1942, it includes Mt Gangan and the endemic plant Pitcairnia feliciana.

Gban Classified Forest

IUCN Category VIII

A 500ha village reserve which has potential as a nature reserve, and may be used by the Japanese for chimpanzee research. It has been recommended for nature reserve status in a government report (Wilson in litt., 1991).

Gbinia Classified Forest

IUCN Category VIII

Established in 1945; 6175ha

Gioumba Classified Forest

IUCN Category VIII

Established in 1956; 12,580ha

Gouba Classified Forest

IUCN Category VIII

Established in 1945; 950ha

Goulgoul-Kankande Classified Forest

Established in 1954; 6800ha

IUCN Category VIII

Grandes Chutes Classified Forest

Established in 1944; 13,400

IUCN Category VIII

Gueme Sangan Classified Forest

IUCN Category VIII

Established in 1955; 2740ha

Gueroual Classified Forest

Established in 1944; 300ha

IUCN Category VIII

Guewel Classified Forest

In Mamou prefecture, established in 1936; 600ha

IUCN Category VIII 
Established in Labe prefecture in 1944 as a forest reserve, this area covers 1300ha. Much of it is degraded, but there are small areas of relict open Fouta Djallon forest present (Wilson in litt., 1991).

Hore-Diama Classified Forest

IUCN Category VIII Established in Labe prefecture in 1936 as a forest reserve, this area covers 1200 ha. Much of it is degraded, but there are small areas of relict open Fouta Djallon forest (Wilson in litt., 1991).

Kabela Classified Forest

IUCN Category VIII

Established in 1955; 3920ha

Kakoulima Classified Forest

IUCN Category VIII A 4350ha forest reserve established in 1944 in Dubreka prefecture. A mixture of secondary and relict moist forest was present in 1980, similar to that in the Kameleya. Threatened plants include Clematis kakoulimensis (Wilson in litt., 1991).

Kakrima Classified Forest

IUCN Category VIII

In Pita prefecture, established in 1955; 238ha

Kala Classified Forest

IUCN Category VIII

Established in 1944; 240ha

Kaloum Classified Forest

IUCN Category VIII

A forest reserve of $672 \mathrm{ha}$ near Conakry, established in 1955. It is probably undergoing urbanisation (Wilson in litt., 1991).

Kambia Classified Forest

IUCN Category VIII

Established in 1944; 520ha

Keniant Classified Forest

IUCN Category V'III

Established in 1943; 3500ha

Khabitaye Classified Forest

IUCN Category VIII

In Dubrecka prefecture, established in 1944; 4900ha

Kolumba Classified Forest

IUCN Category VIII

Established in 1943; 1230ha

Kombi Tide Classified Forest

IUCN Category VIII

Established in 1941; 170ha 
Konkoure Fetto Classified Forest

IUCN Category VIII

Established in 1945; 1200ha

Kora Classified Forest

IUCN Category VIII

Established in 1955; 750ha

Koulou Classified Forest

IUCN Category VIII

Established in 1978; 90ha

Koumban-Kourou Classified Forest

IUCN Category VIII

Established in 1942; 4000ha

Kouradi Classified Forest

Established in 1942; 3000ha

IUCN Category VIII

Kourani-Oulete-Diene Classified Forest

IUCN Category VIII

Situated in Kankan prefecture, this forest reserve of 59,000 ha was originally established in 1942. A revision of its boundaries, suggested in a government report, is to extend the reserve to the east and west and to exclude cleared areas in the north (Wilson in litt., 1991).

Kouya Classified Forest

IUCN Category VIII

Established in 1952; 67,400ha

L'Amana Classified Forest

IUCN Category VIII

Established in 1952; 19,800ha

Lac de Pita Classified Forest

In Pita prefecture, established in $1955 ; 24$ ha

IUCN Category VIII

Laine Classified Forest

established in 1955; 203ha

IUCN Category VIII

Lefarani Classified Forest

IUCN Category VIII

Established in 1943; 1900ha

Ley-Billel Classified Forest

In Labe prefecture, established in 1955; $172 \mathrm{ha}$

IUCN Category VIII

Loffa Classified Forest

Established in 1945; 700ha

IUCN Category VIII

Lombha Classified Forest

Established in 1967; 90ha

IUCN Category VIII 

established in 1952. Relict moist evergreen forest transitional with semi-deciduous forest covers over $15,000 \mathrm{ha}$. It has so far not been badly affected by fire, which is resulting in a degeneration towards savanna, and population pressure is relatively low. It has important potential for threatened plants (Wilson in litt., 1991). 
Mt Konossou Classified Forest

IUCN Category VIII

Situated in Gueckedou prefecture, this forest reserve of 2680 ha was established in 1955. It is important for the plant Adamea stenocarpa, which has been designated as Vulnerable (Wilson in litt., 1991).

Mt Kouya Classified Forest IUCN Category VIII

Established in 1943; 303ha

Mt Loura Classified Forest

Established in 1955; 530ha

IUCN Category VIII

Mt Salia Classified Forest

IUCN Category VIII

In Coyou prefecture, established in 1942; 4840ha

Mt Tetini Classified Forest

Established in $1955 ; 23,500 \mathrm{ha}$

IUCN Category VIII

Mt Yonon Classified Forest

In Nzerekore prefecture, established in 1950; 4750ha

IUCN Category VIII

Myalama Classified Forest

In Lelouma prefecture, established in 1943; 10,000ha

IUCN Category VIII

N'Dama Classified Forest

IUCN Category VIII

Situated in Koundara prefecture, and originally gazetted as a forest reserve in 1954, this forest reserve covers 67,000 ha. Primarily a mosaic of dry forest and woodland rumoured to support little large wildlife, it is of particular interest for its possible dry forest and bamboo formations (Wilson in litt., 1991).

N'Guidou Classified Forest

Established in 1954; 18ha

IUCN Category VIII

Nimba Piedmont Classified Forest

Established in 1954; 18ha

IUCN Category VIII

Nono Classified Forest

IUCN Category VIII

Situated in Kouroussa prefecture; an area of 5600 ha was originally established as a forest reserve in 1936 to supply fuel for a railway. There are good stands of Isoberlinia, but the forest is threatened by expanding agriculture. An extension of about 22,000ha has been suggested (Wilson in litt., 1991).

Nzo Classified Forest

8000 ha

IUCN Category VIII

Ore-Djima Classified Forest

Established in 1936; 1200ha

IUCN Category VIII 
Situated in Beyla prefecture, this area was originally established as a forest reserve of 25,600 ha in 1953. It includes degraded dense moist submontane forest and is drier than Ziama, with moist forest grading into semi-deciduous forest. It has been degraded by fire, but is likely to be important for endemic plants (Wilson in litt., 1991).

Established in 1945; 6075ha

Pincely Classified Forest

IUCN Category VIII Situated in Mamou prefecture, this was originally established in 1945 as a forest reserve covering $13,000 \mathrm{ha}$. It includes relict gallery forest similar in species composition to evergreen moist forest, which has elsewhere been now largely destroyed. A high proportion of species are fire-resistant, e.g. Podocarpus erinaceus and Terminalia glaucescens, and are considered useful in watershed protection (Wilson in litt., 1991).

Pissonon Classified Forest

IUCN Category VIII 250ha

\section{Sala Classified Forest}

In Labe prefecture, established in 1945; 568ha

IUCN Category VIII

Samba la "Ton" Classified Forest

In Siguiri prefecture, established in $1986 ; 600$ ha

IUCN Category VIII

Sambalankan Classified Forest

IUCN Category VIII Situated in Pita prefecture, and originally established in 1952 as a 3500 ha forest reserve. Some areas of true open dry forest are included (Wilson in litt., 1991).

Saraboli Classified Forest

IUCN Category VIII

Established in 1952; 850ha

Selly-Koro Classified Forest

IUCN Category VIII

In Kissidougou prefecture, established in 1951; 2300ha

Sere Classified Forest

IUCN Category VIII

In Mamou prefecture, established in 1936; 315 ha 
Sources de Dinguiraye Classified Forest

Established in 1951; 71 ha

IUCN Category VIII

Soutouyanfon Classified Forest

Established in $1943 ; 11,000$ ha

IUCN Category VIII

Soyah Classified Forest

IUCN Category VIII

Established in 1945; 8400ha

Tafsirla Classified Forest

Established in 1961; 1780ha

IUCN Category VIII

\section{Tamba Classified Forest}

IUCN Category VIII Situated in Kouroussa prefecture; an area of 15,000 ha was originally established as a forest reserve in 1945 to supply fuel for a railway. There are good stands of Isoberlinia, and it is a potential site for trials of natural forest management for this species. However, it is threatened by expanding agriculture (Wilson in litt., 1991).

\section{Tamba-nord Classified Forest}

IUCN Category VIII In Kouroussa prefecture; an area of 1250 ha was originally established as a forest reserve in 1943 to supply fuel for a railway. There are good stands of Isoberlinia, but it is threatened by expanding agriculture (Wilson in litt., 1991). In Kouroussa prefecture; an area of 1360 ha was originally established as a forest reserve in 1945 to supply fuel for a railway. There are good stands of Isoberlinia but it is threatened by expanding agriculture (Wilson in litt., 1991). 
Established in 1978; 462ha

Tialakoun Classified Forest

IUCN Category VIII

In Labe prefecture, established in 1943; 336ha

Tinka Classified Forest

IUCN Category VIII

Situated in Dalaba prefecture, this $540 \mathrm{ha}$ area was originally established as a forest reserve in 1944. It is one of the least degraded forests in the area as, outside of reserves, there is very little forest left in this prefecture (Wilson in litt., 1991).

Tolole Classified Forest

IUCN Category VIII

200ha

Tomine-Koumba Classified Forest

IUCN Category VIII

Established in 1954; 36,000ha

Vonn Classified Forest

IUCN Category VIII

240ha

Wonkon Classified Forest

IUCN Category VIII

Established in 1967; 282ha

Yardo Classified Forest

In Kissidougou prefecture, established in 1956; 4096ha

IUCN Category VIII

Yoton Classified Forest

In Nzerekore prefecture, established in 1950; 4750 ha

IUCN Category VIII

\section{UNPROTECTED AREAS}

Alcatraz see Ile Alcatraz

Bafing-Tinkisso

These forested area in the north are of ecological interest (Bourque and Wilson, 1990).

\section{Boffa Mangroves}

$10^{\circ} 10^{\prime} \mathrm{N}, 14^{\circ} 02^{\prime} \mathrm{W} 46,000$ ha of mangroves occur on the Pongo River estuary near Boffa. Species include Rhizophora harrisonii, $R$. racemosa, Avicennia africana and Laguncularia racemosa. The area is probably important for waterfowl, and Nile crocodile, pygmy hippopotamus, pygmy antelope, bushpig, bushbuck, otters and mona monkeys occur (Altenburg, 1987).

Bossou Forest

$7^{\circ} 39^{\prime} \mathrm{N}, 8^{\circ} 30^{\prime} \mathrm{W}$ This is a potential protected area near Nimba. 
Diécké National Park

Proposed

$7^{\circ} 35^{\prime} \mathrm{N}, 9^{\circ} 00^{\prime} \mathrm{W}$ Diécké Forest Reserve consists of lowland rain forest in the southeast of the country, south of Nzerekore. An area of 55,600ha is proposed for national park status. The 100 species of bird recorded include rare and threatened species. A wide variety of forest fauna occurs, including golden cat, leopard, pygmy hippopotamus, dwarf crocodile, buffalo, the duiker Cephalophus zebra, and bongo; the six primate species include chimpanzee, Cercocebus atys and Procolobus polykobus (Bourque and Wilson, 1990).

\section{Forécariah Mangroves}

$9^{\circ} 15^{\prime} \mathrm{N}, 13^{\circ} 17^{\prime} \mathrm{W}$ These are large areas of probably freshwater swamps, as well as mudflats and mangroves on the southern coastline. They are likely to be important for waterfowl, and Nile crocodile, pygmy hippopotamus, pygmy antelope, bushpig, bushbuck, otters and mona monkeys occur (Altenburg, 1987).

\section{Forêt de Kameleya}

Also known as Kounoukan, this forest is situated in Forecariah prefecture. It was to be gazetted, but the process was interrupted by independence and not completed; the area has been recommended for priority conservation action. It is treated as a forest reserve, and is a relatively well-conserved area of coastal semi-deciduous moist forest, the only example left in Guinée Maritime, as many species are light-demanding and sensitive to burning. It is situated at an altitude of about $1200 \mathrm{~m}$, and rocky outcrops probably support the rockfowl Picathartes gymnocephalus; it has potential for importance in terms of endemic plants (Wilson in litt., 1991).

\section{Forêt Koba-Niger Classified Forest}

Proposed Also known as Forokonia, this is situated in Faranah prefecture and originally established as a forest reserve of $4770 \mathrm{ha}$ in 1945 . It includes an area of natural evergreen forest, with Lophira alata, Pitadeniastrum africanum and Terminalia ivorensis.

\section{Forêt de Moybeya}

In Dalaba prefecture and originally established as a forest reserve in 1943, this area covers 225 ha. Closed canopy moist evergreen forest still remains (although degraded), but outside the reserves there is very little forest left in this prefecture (Wilson in litt., 1991).

\section{Forêt de Nzo}

Situated in Lola prefecture, an area of about 8000 ha has been proposed for protection as a forest reserve (Wilson in litt., 1991).

Forêt de Tana Classified Forest

22,000 ha 
Situated in Siquiri prefecture, an area of $60,000 \mathrm{ha}$ has been proposed as a forest reserve in a government report (Wilson in litt., 1991).

\section{Foronkonia - see Forêt Source du Niger}

\section{Ile de Naufrage}

About $2-3 \mathrm{~km}$ off the southern end of the island of Alkatraz $\left(10^{\circ} 38^{\prime} \mathrm{N}, 15^{\circ} 23^{\prime} \mathrm{W}\right)$, this islet is an elongated, unvegetated $125 \times 20 \mathrm{~m}$ sandbank, covering $0.25 \mathrm{ha}$ at high tide. It reaches $3 \mathrm{~m}$ above sea-level. On the eastern side there is a trace of reef at low tide. It is used as a roost and high water refuge by about 4500 terns, particularly royal, black, little and common terns. Brown booby probably use it as a roosting site, and a few waders visit the island. Fishermen rarely visit because of the distance from the mainland, and the difficulty in landing there (WIWO, 1989).

\section{Isles do Los}

These are a group of small islands, which are a possible avocet roost, off the rocky Conakry peninsula (Altenburg, 1987).

\section{Iles Tristao - see Tristao Islands}

\section{Kankan Partial Faunal Reserve}

In Kankan prefecture near Karala, this reserve has probably been degazetted. Kankan Classified Forest is listed as covering $82,120 \mathrm{ha}$. Large tracts of dense dry forest with numerous gallery forests are included, but are being rapidly cleared for agriculture in parts. It is an area with a high incidence of river blindness, and may therefore be more suitable as a reserve than as farmland. Some areas have been converted into village forest reserves. Forest reserve status has been suggested for the forests in the Karala area of the old reserve, in a government report (Wilson in litt., 1991).

\section{Mafou Forests}

This is a forested area in the centre of the country (Bourque and Wilson, 1990).

Ouré-Kaba Forest Reserve

Proposed $10^{\circ} 06^{\prime} \mathrm{N}, 11^{\circ} 50^{\prime} \mathrm{W}$ A transitional zone between rain forest and woodland, this reserve is on the border with Sierra Leone (Bourque and Wilson, 1990).

\section{Rio Komponi (Kogon) and Rio Nunez Mangroves}

$10^{\circ} 51^{\prime} \mathrm{N}, 14^{\circ} 42^{\prime} \mathrm{W} 124,000 \mathrm{ha}$ of tidal forest, up to $30 \mathrm{~km}$ in width and with a canopy height of up to $40 \mathrm{~m}$ high, occur on these two estuaries. Mangrove species include Rhizophora harrisonii, $R$. racemosa, Avicennia africana and Laguncularia racemosa. They are backed by periodically inundated freshwater swamps, especially along the Nunez River. Nile crocodile, pygmy hippopotamus, pygmy antelope, bushpig, bushbuck, otters and mona monkeys occur (Altenburg, 1987; Hughes and Hughes, 1992). 


\section{Sangaréya Bay Mangroves}

$9^{\circ} 47^{\prime} \mathrm{N}, 13^{\circ} 43^{\prime} \mathrm{W} 28,000 \mathrm{ha}$ of mangroves occur on the southern bank of the Konkouré River estuary, and around the head of the bay. Species include Rhizophora harrisonii, $R$. racemosa, Avicennia africana and Laguncularia racemosa. Nile crocodile, pygmy hippopotamus, pygmy antelope, bushpig, bushbuck, otters and mona monkeys occur (Altenburg, 1987; Hughes and Hughes, 1992). 
GUINEA - PROTECTED SITES

National/international designations

Name of area and

Management

Year

map reference (see Fig. 8.1)

area (ha)

notified

Classified Forests

1 Badiar-sud

2 Bagata

3 Bakoum

4 Balayan-Souroumba

5 Bambaya

6 Bani

7 Banie

8 Bantarawel

9 Baro

10 Beauvois

11 Beko

12 Bellel

Beyla

13 Binti

14 Botokoly

15 Boula

16 Chutes de Kinkon

17 Chutes de Tinkisso

18 Colline-Macenta

19 Counsignaki

20 Damakhania

21 Dara-Labe

22 Darawondi

23 Darou-salam

24 Diecke

25 Diego Tamba

26 Diogoure

27 Dixinn

28 Djimbera (Bantiguel)

29 Dokoro

30 Fanafanako

31 Fello Digui

32 Fello Diouma

33 Fello Sounga

34 Fello-Selouma

35 Fello-Touni

36 Fitacouna

37 Fougoumba
7,300

2,000

28,000

25,000

336

18,900

23,160

675

8,000

2,300

800

1,350

381

410

2,300

27,500

320

1,100

780

13,700

425

375

30

17,474

64,000

70

1,000

3,900

700

7,800

380

2,925

418

6,700

4,000

100

95

795
1956

1942

1951

1951

1951

1952

1956

1936

1943

1945

1943

1944

1956

1944

1942

1955

1955

1944

1945

1955

1944

1943

1978

1954

1945

1946

1943

1944

1983

1952

1986

1967

1936

1953

1955

1983

1942

1944 
Ecologically Sensitive Sites of Africa

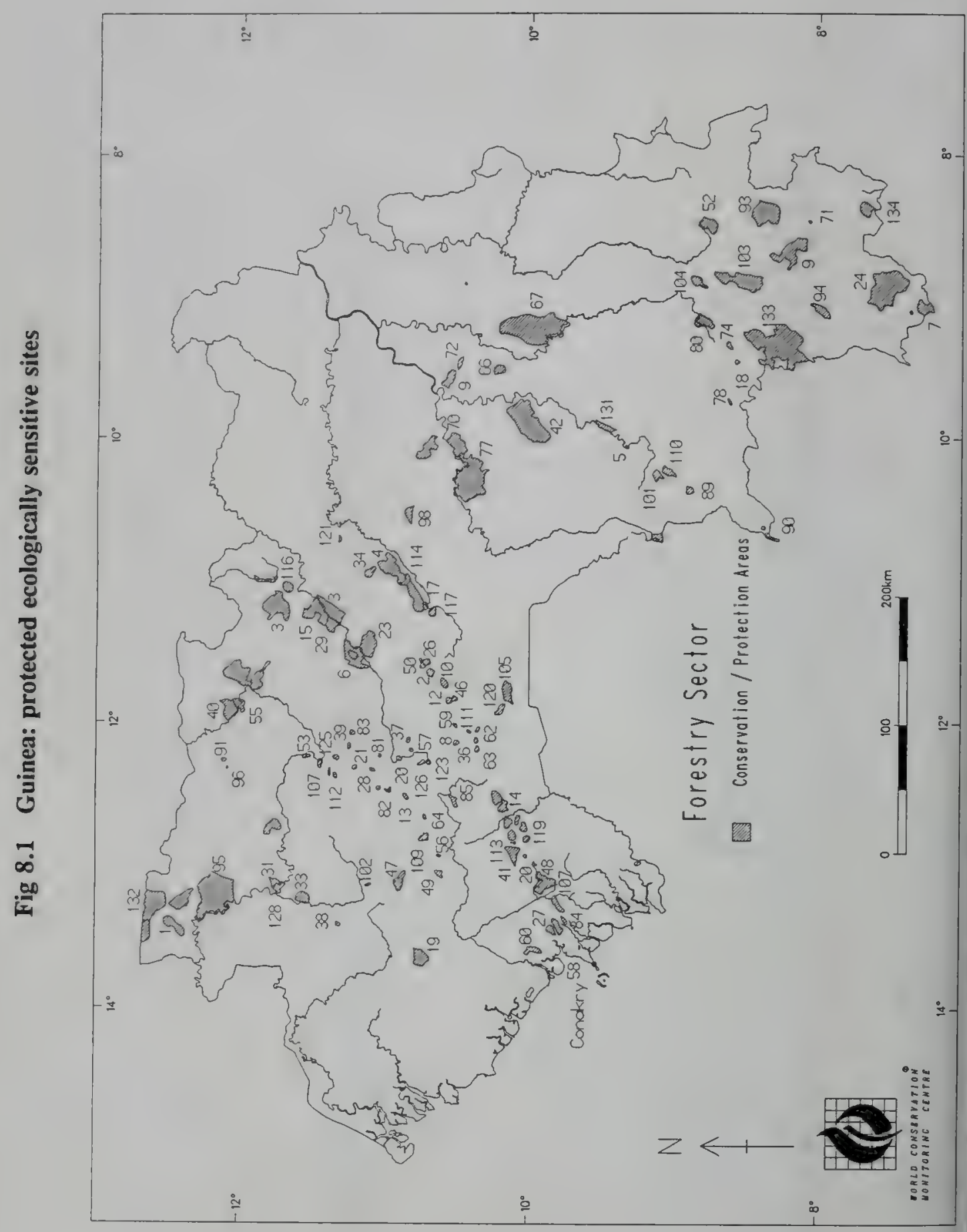


GUINEA - PROTECTED SITES (cont.)

National/international designations

Name of area and

map reference (see Fig. 8.1)

$\begin{array}{ll}\begin{array}{c}\text { Management } \\ \text { area (ha) }\end{array} & \begin{array}{l}\text { Year } \\ \text { notified }\end{array}\end{array}$

38 Foye-Madinadian

39 Galy

40 Gambi

41 Gangan

42 Gban

43 Gbinia

44 Gioumba

45 Goto

46 Gouba

47 Goulgoul-Kankande

48 Grandes Chutes

49 Gueme Sangan

50 Gueroual

51 Guewel

52 Guirila

53 Haute-Komba

54 Hoo

55 Kabela

56 Kakrima

57 Kala

58 Kaloum

59 Kambia

60 Khabitaye

61 Kolumba

62 Koni

63 Konkoure Fetto

64 Kora

65 Koulou

66 Koumban-Kourou

67 Kourani-Oulete-Dienne

68 Kouya

69 Koyoto

70. L'Amana

71 Laine

72 Lefarani

73 Ley-Billel

74 Loffa

75 Lombha

76 Lombonye

77 Mafou
$1,595 \quad 1954$

$1,500 \quad 1943$

$15,500 \quad 1955$

500

$6,175 \quad 1945$

$12,580 \quad 1956$

120

950

6,800

13,400

2,740

300

600

8,100

1,300

150

3,920

238

240

672

520

4,900

1,230

116

1,200

750

90

4,000

59,000

67,400

320

19,800

203

1,900

172

700

90

350

52,400
$9,000 \quad 1942$
1945

1954

1944

1955

1944

1936

1954

1944

1955

1955

1944

1955

1944

1944

1943

1945

1955

1978

1942

1942

1952

1952

1955

1943

1955

1945

1967 
GUINEA - PROTECTED SITES (cont.)

National/international designations

Name of area and

map reference (see Fig. 8.1)

$\begin{array}{ll}\text { Management } & \text { Year } \\ \text { area (ha) } & \text { notified }\end{array}$

78 Makona

79 Mankiti

80 Milo

81 Mirire

82 Miti Kambadaga

83 Mombeya

84 Mt. Balan

85 Mt. Balandougou

86 Mt. Banan

87 Mt. Bero

88 Mt. Gouba

89 Mt. Konossou

90 Mt. Kouya

91 Mt. Loura

92 Mt. Salia

93 Mt. Tetini

94 Mt. Yonon

95 N'Dama

96 N'Guidou

97 Nimba Piedmont

98 Nono

99 Nzo

100 Ore-Djima

101 Ouladin

102 Paradji

103 Pic de Fon

104 Pic de Tibe

105 Pincely

106 Pissonon

107 Sala

108 Samba la "Ton"

109 Sambalankan

110 Selly-Koro

111 Sere

112 Serima

113 Sierra-Fore

114 Sincery-Ourssa

115 Singuelema

116 Sobory

117 Souarela
1942

1985

1942

1944

1944

1943

1952

1945

1950

1952

1945

1955

1943

1955

1942

1955

1950

1956

1954

1943

1936

1936

1950

1955

1953

1945

1945

1945

1986

1952

1951

1936

1943

1942

1942

1978

1956

1944 
GUINEA - PROTECTED SITES (cont.)

National/international designations

Name of area and

map reference (see Fig. 8.1)

Management

area (ha)

118 Sources de Dinguiraye

119 Sources de Kindia

120 Soyah

121 Tafsirla

122 Tamba

123 Tangama

124 Teliko

125 Tialakoun

126 Tinka

127 Tolole

128 Tomine Koumba

129 Vonn

130 Wonkon

131 Yardo

National Park

132 Badiar

Strict Nature Reserves

133 Massif du Ziama

134 Mount Nimba

Biosphere Reserves

Réserve de la Biosphère des

Monts Nimba

Réserve de la Biosphère du Massif du Ziama

Ramsar Wetland Sites

Ile Alcatraz

Iles Tristao

Konkoure

Rio Kapatchez

Rio Pongo

World Heritage Sites

Mount Nimba Strict Nature

Reserve

$\begin{array}{rl}71 & 1951 \\ 70 & 1943 \\ 8,400 & 1945 \\ 1,780 & 1961 \\ 15,000 & 1945 \\ 410 & 1944 \\ 462 & 1978 \\ 336 & 1943 \\ 540 & 1944 \\ 200 & \\ 36,000 & 1954 \\ 240 & \\ 282 & 1967 \\ 4,096 & 1956\end{array}$

38,200

1985

116,170

1943

13,000

1944

17,130

1980

116,170

1980

1992

1992

1992

1992

1992

20,000

30,000

13,000

1981 


\section{GUINEA - UNPROTECTED SITES}

Name of area and

map reference (see Fig. 8.2)
Management

area (ha)

9

1

14

4 Diécké National Park

5 Forécariah Mangroves

Forêt de Kameleya

Foret Koba-Niger Classified Forest Reserve

Forêt de Moybeya

Forêt de Nzo

Forêt de Tana

Forêt de Tinkisso-nord

6 Ile de Naufrage

Isles do Los

Kamalaya (Kounounkan)

5,032

Kankan Partial Faunal Reserve

Mafou Forests

7 Oure-Kaba Forest Reserve

8 Rio Komponi (Kogon) and Rio Nunez Mangroves

9 Sangaréya Bay Mangroves

10 Tristao Islands 


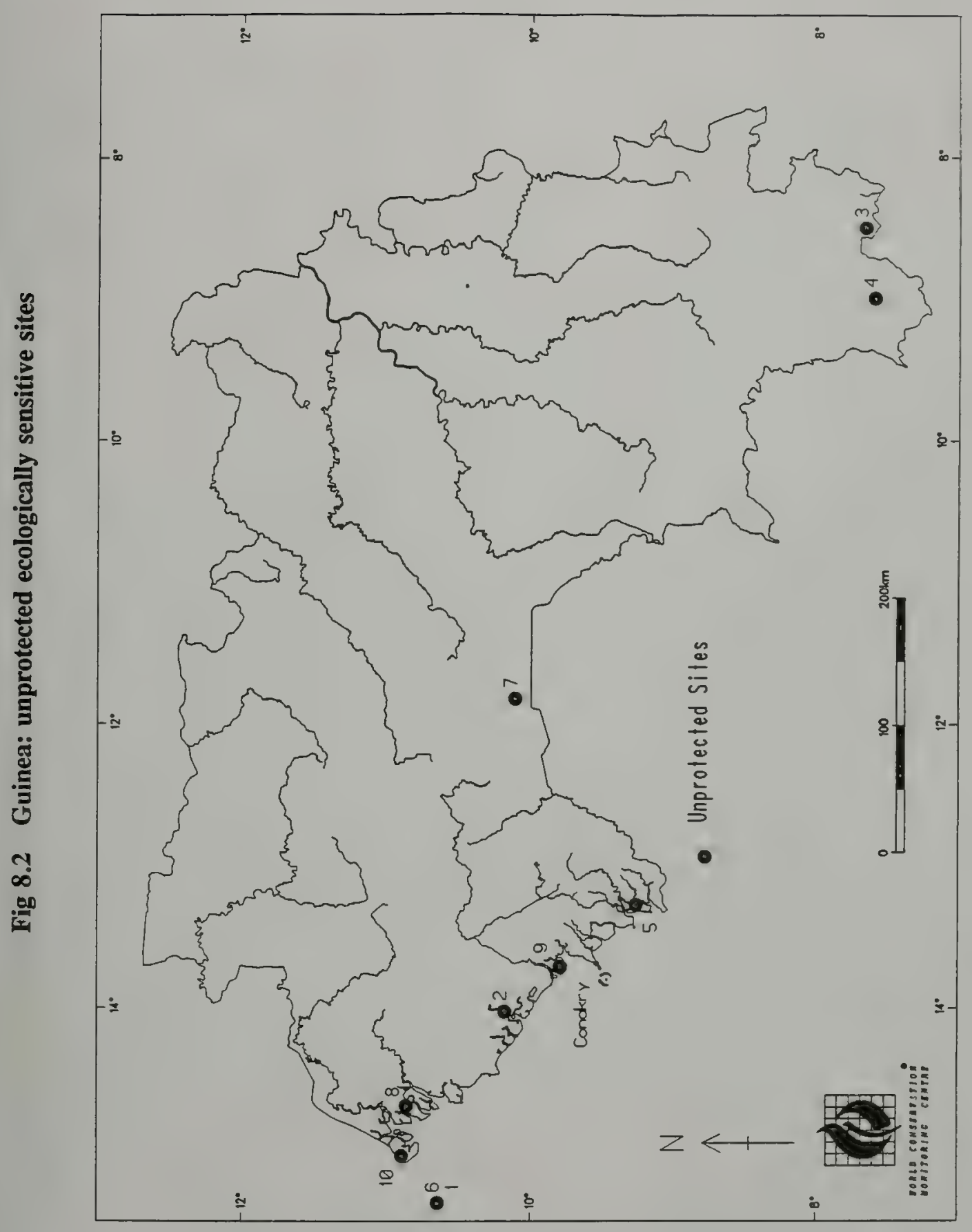





\section{TOGO}

INTERNATIONALLY DESIGNATED PROTECTED AREAS

None

NATIONALLY PROTECTED AREAS

Abdoulaye Faunal Reserve

IUCN Category IV

$8^{\circ} 30^{\prime}-8^{\circ} 45^{\prime} \mathrm{N}, 1^{\circ} 05^{\prime}-1^{\circ} 30^{\prime} \mathrm{E} 30,000$

Akaba Faunal Reserve

$7^{\circ} 40^{\prime}-8^{\circ} 00^{\prime} \mathrm{N}, 1^{\circ} 00^{\prime}-1^{\circ} 30^{\prime} \mathrm{E} 25,626 \mathrm{ha}$

IUCN Category IV

Aledjo Faunal Reserve

IUCN Category IV

$9^{\circ} 15^{\prime}-9^{\circ} 20^{\prime} \mathrm{N}, 1^{\circ} 00^{\prime}-1^{\circ} 15^{\prime} \mathrm{E} 765 \mathrm{ha}$

Djamde Faunal Reserve

$8^{\circ} 50^{\prime}-9^{\circ} 45^{\prime} \mathrm{N}, 0^{\circ} 45^{\prime}-1^{\circ} 00^{\prime} \mathrm{E}$ 1650ha

IUCN Category IV

Fazao-Malfakassa National Park

IUCN Category II

This park of 192,000 ha comprises a mountainous region with two major north-south ridges, cliffs up to $200 \mathrm{~m}$, and sheer knife-edged ridges. Areas of savanna woodland, extensive gallery forest and sub-montane forest occur, and the park includes the largest and most undisturbed area of natural vegetation in Togo. Several threatened species such as chimpanzee and elephant occur, but poaching is a severe problem, particularly near the borderwith Ghana. Poaching and illegal honey gathering take place, and low staffing levels make these problems difficult to control. There is a high tourism potential, but a lack of infrastructure and funds for development (IUCN/UNEP, 1987).

Fosse aux Lions National Park

IUCN Category II The park covers 1650 ha of a low-lying plain which is predominantly vegetated with grass savanna, whilst gallery forest occurs along rivers. Larger mammals include elephant, warthog, red-flanked duiker, kob and buffalo. Poaching and cattle grazing have been almost stopped by the increasing enforcement of strict control measures (IUCN/UNEP, 1987).

Galangashie Faunal Reserve $10^{\circ} 15^{\prime}-10^{\circ} 25^{\prime} \mathrm{N}, 0^{\circ} 08^{\prime}-0^{\circ} 25^{\prime} \mathrm{E} 7500 \mathrm{ha}$

IUCN Category IV

Haho-Yoto Faunal Reserve

$6^{\circ} 40^{\prime}-7^{\circ} 00^{\prime} \mathrm{N}, 1^{\circ} 15^{\prime}-1^{\circ} 40^{\prime} \mathrm{E} 8000 \mathrm{ha}$

IUCN Category IV

Keran National Park

IUCN Category II

This park of 163,640 ha lies in a very flat area, including the floodplain of the annual Koumongou River; this river dries to a few isolated pools in the dry season, but floods quickly in response to rains upstream. The park supports a wooded savanna with 
gallery forest along streams, and supports a variety of mammals including many ungulates, and threatened species such as elephant and leopard. Poaching and grazing occur on a small scale, but strict anti-poaching measures exist with frequent patrolling and large fines for killing animals or starting fires. A number of artificial waterholes have been provided, and controlled fires are used each year in order to improve grazing. The international road from Lomé to Burkina Faso crosses the park, but a $50 \mathrm{kph}$ speed limit has been imposed in an attempt to reduce road casualties (IUCN/UNEP, 1987).

Kpessi Faunal Reserve

$8^{\circ} 00^{\prime}-8^{\circ} 15^{\prime} \mathrm{N}, 1^{\circ} 00^{\prime}-1^{\circ} 30^{\prime} \mathrm{E} 28,000 \mathrm{ha}$

IUCN Category IV

Oti Mandouri Faunal Reserve

IUCN Category IV

$10^{\circ} 20^{\prime}-11^{\circ} 00^{\prime} \mathrm{N}, 0^{\circ} 30^{\prime}-0^{\circ} 55^{\prime} \mathrm{E}$ Situated in the north-east of the country, this 147,840 ha reserve forms a near-link between the protected areas of northern Togo and Pendjari National Park in Benin. Wildlife populations are increasing. The area is a wintering ground for up to 500 crowned cranes (Stuart et al., 1990).

Togodo Faunal Reserve

IUCN Category IV

This reserve covers an area of $31,000 \mathrm{ha}$, and is situated on a peneplain crossed by several rivers. Wooded savanna predominates, with gallery forest along watercourses. The larger mammalian fauna includes buffalo, hippopotamus, Buffon's kob and bushbuck, but poaching and agricultural encroachment occur. A dam is being constructed upstream on the Mono River (IUCN/UNEP, 1987).

\section{OTHER MANAGED AREAS}

Kamassi Nature Reserve

$9^{\circ} 99^{\prime} \mathrm{N}, 1^{\circ} 99^{\prime} \mathrm{E} 17,000 \mathrm{ha}$

Koue Nature Reserve

$9^{\circ} 99^{\prime} \mathrm{N}, 0^{\circ} 50^{\prime} \mathrm{E}$ 40,000ha

\section{UNPROTECTED SITES}

\section{Lake Togo}

$6^{\circ} 14^{\prime} \mathrm{N}, 1^{\circ} 25^{\prime} \mathrm{E}$ This area includes the Anécho Lagoons, and the extensive freshwater marshes along the Zio and Mono rivers; small areas of mangrove and mudflats occur. The area is of importance to waterfowl and waders (Altenburg, 1987). 


\section{TOGO - PROTECTED SITES}

National/international designations

Name of area and

map reference (see Fig. 9.1)

Management Year area (ha) notified

\section{Faunal Reserves}

1 Abdoulaye

2 Akaba

3 Aledjo

4 Djamde

5 Galangashie

6 Haho-Yoto

7 Kpessi

8 Oti Mandouri

9 Togodo

National Parks

10 Fazao-Malfakassa

11 Fosse aux Lions

12 Keran

$\begin{array}{rr}30,000 & 1951 \\ 25,626 & \\ 765 & 1959 \\ 1,650 & 1954 \\ 7,500 & 1954 \\ 18,000 & 1955 \\ 28,000 & \\ 147,840 & \\ 31,000 & 1952\end{array}$

192,000

1951

$1,650 \quad 1954$

$163,640 \quad 1950$ 
Ecologically Sensitive Sites of Africa

Fig 9.1 Togo: protected ecologically sensitive sites

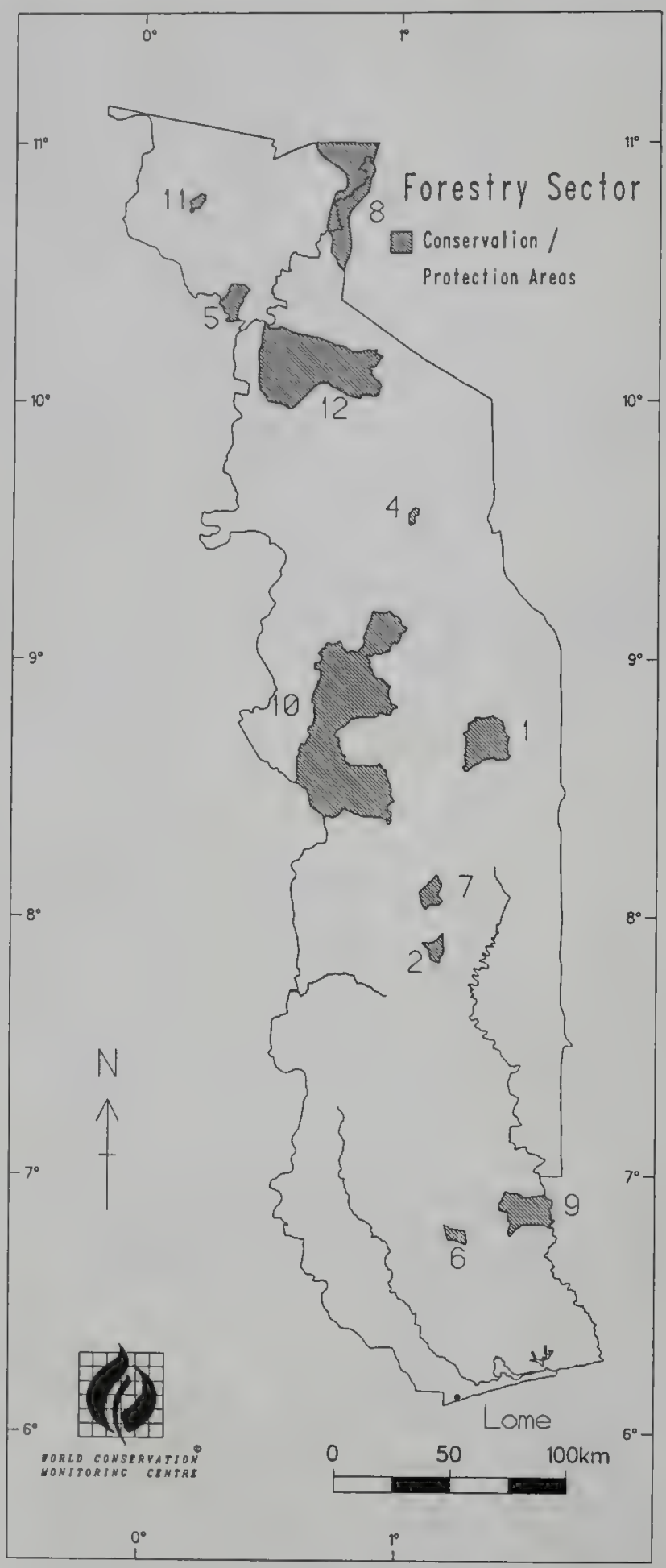




\section{TOGO - UNPROTECTED SITES}

Name of area and

map reference (Fig 9.2)

1 Lake Togo 
Ecologically Sensitive Sites of Africa

Fig 9.2 Togo: unprotected ecologically sensitive sites

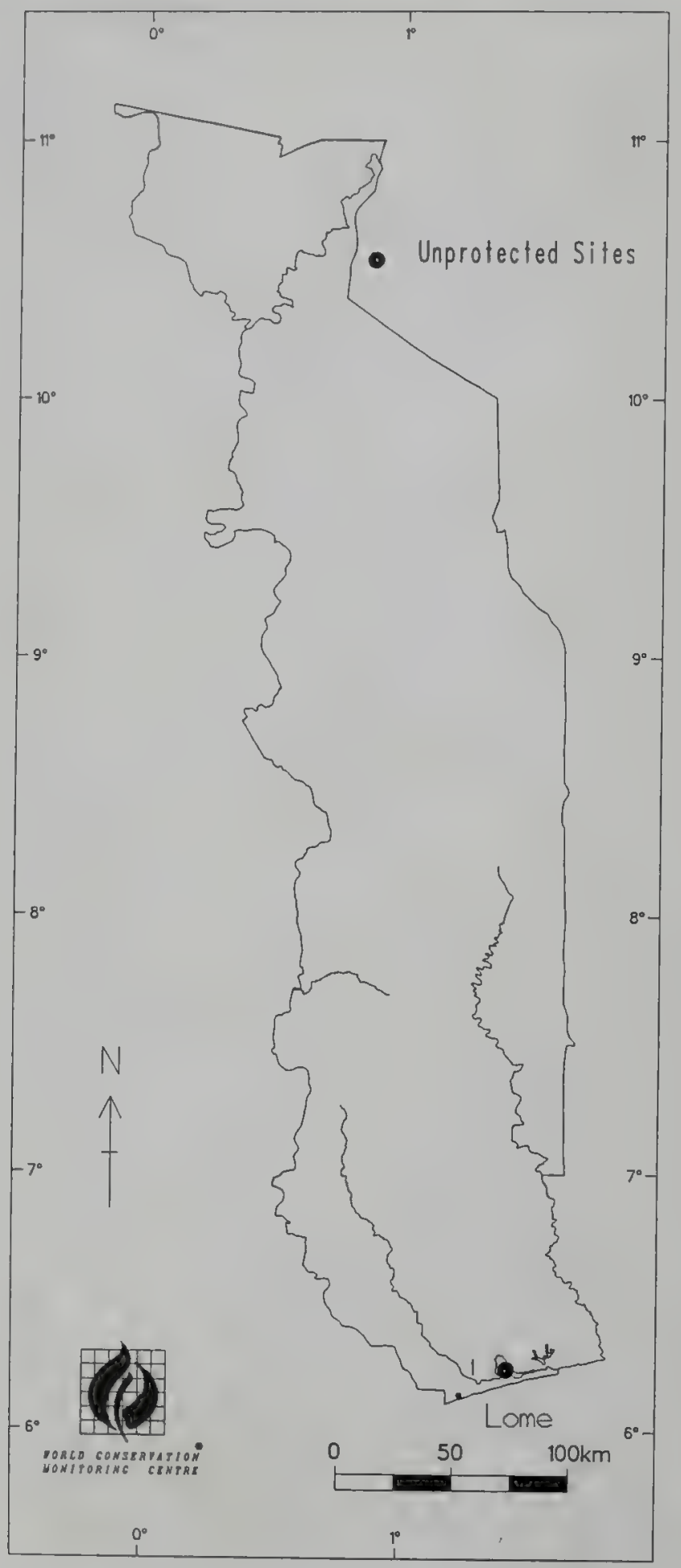




\section{REFERENCES}

Altenburg, W. 1987. Waterfowl in West African coastal wetlands. WIWO Report 15. $\mathrm{BBC}$ 1990. Troubles at the source of life. $B B C$ Wildlife September.

Bourque, J.D. and Wilson, R. 1990. Au rapport de l'étude d'impact écologique d'un projet d'aménagement forestier concernant les forêts classées de Ziama et de Diécké en République de Guinée: Guinea forestry biodiversity study - Ziama and Diécké Reserves. Unpublished report, July 1990. IUCN, Gland, Switzerland.

Burgis, M.J. and Symoens, J.J. 1987. African Wetlands and Shallow Water Bodies. ORSTOM, Paris.

Collar, N.J. and Stuart, S.N. 1988. Key Forests for Threatened Birds in Africa. ICBP Monograph No. 3. International Council for Bird Preservation, Cambridge.

Frame, G.W. 1987. African forest sites. Unpublished report.

Gartlan, S. 1989. La Conservation des Ecosystèmes forestiers du Cameroun. IUCN, Gland, Switzerland and Cambridge, UK. 186pp.

Harrison, M.J.S. 1990. A recent survey of the birds of Pagalu (Annobon). Malimbus $11: 135-143$.

Hughes, R.H. and Hughes, J.S. 1992. A Directory of African Wetlands. IUCN, Gland, Switzerland and Cambridge, UK/UNEP, Nairobi, Kenya/WCMC, Cambridge, UK.

IUCN 1987. Action Strategy for Protected Areas in the Afrotropical Realm. IUCN, Gland, Switzerland and Cambridge, UK. 56pp.

IUCN 1989. La Conservation des Ecosystèmes forestiers du Congo. IUCN, Gland, Switzerland and Cambridge, UK. 187pp.

IUCN 1990a. La Conservation des Ecosystèmes forestiers du Gabon. IUCN, Gland, Switzerland and Cambridge, UK. 215pp.

IUCN 1990b. La Conservation des Ecosystèmes forestiers du Zaïre. IUCN, Gland, Switzerland and Cambridge, UK. 242pp.

IUCN/UNEP 1987. The IUCN Directory of Afrotropical Protected Areas. IUCN, Gland, Switzerland and Cambridge, UK.

Maché, E. and Mousa Touré, A. 1990. The Pendjari National Park - what a project can achieve. Nature et Faune 6:39-43.

MacKinnon, J. and MacKinnon, K. 1986. Review of the Protected Areas System in the Afrotropical Realm. IUCN, Gland, Switzerland and Cambridge, UK, and UNEP. $259 \mathrm{pp}$.

MALFF 1991. Elephant Conservation Plan. Equatorial Guinea. Ministry of Agriculture, Livestock, Fisheries and Forestry. 44pp.

Sinsin, B. and Heymans, J.C. 1988. Problèmes liés à la transhumance des animaux domestiques à travers les parcs nationaux. Nature et Faune 4:27-31.

Stuart, S.N. (Ed.) 1986. Conservation of Cameroon Montane Forests. ICBP, Cambridge, England. 263pp.

Stuart, S.N., Adams, R.J. and Jenkins, M.D. 1990. Biodiversity in Sub-Saharan Africa and its Islands. Occasional Paper No. 6. IUCN Species Survival Commission. 
WCMC 1988a. Gabon - conservation of biological diversity. Draft. World Conservation Monitoring Centre, Cambridge.

WCMC 1991. Côte d'Ivoire - La conservation de la diversité biologique. World Conservation Monitoring Centre, Cambridge.

WIWO 1989. Etude ornithologique préliminaire de la zone côtière du nord-ouest de la Guinée. ICBP, Cambridge. 


Other volumes in the set:

Volume II: Eastern Africa

Volume III: South-Central Africa and Indian Ocean

Volume IV: West Africa

Volume V: Sahel

Volume VI: Southern Africa 